$N$
40,1

R179A52

1917

NMAA

AMERICAN PAINTINGS

\title{
WORKS OF THE LATE
}

HENRY WARD RANGER, N.A.

AT THE AMERICAN ART GALLERIES MADISON SQUARE SOUTH NEW YORK 



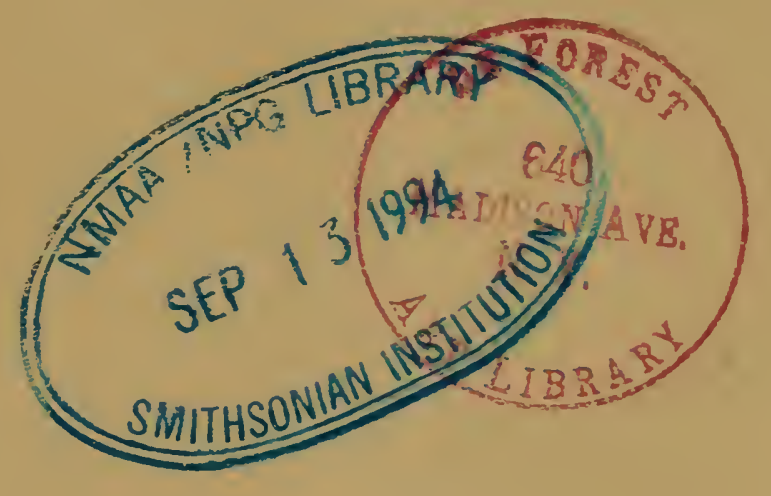



ON FREE PUBLIC VIEW

AT THE AMERICAN ART GALLERIES

MADISON SQUARE SOUTH, NEW YORK

BEGINNING SATURDAY, MARCH 24TH, 1917

AND CONTINUING UNTIL THE TIME OF SALE

\section{COMPLETED PICTURES}

BY THE LATE

HENRY WARD RANGER, N.A.

TO BE SOLD AT UNRESTRICTED PUBLIC SALE

BY ORDER OF

MR. CHARLES HENRY PHELPS

AND

MR. WILLIAM MACBETH

EXECU'TORS

ON THE EVENINGS OF THURSDAY AND FRIDAY

MARCH 29TH AND 30TH, 1917

BEGINNING AT 8.15 O'CLOCK

IN THE ASSEMBLY ROOM OF

THE AMERICAN ART GALLERIES 

ILLUSTRATED CATALOGUE

$\mathrm{OF}$

\section{THE COMPLETED PICTURES}

LEFT BY THE LATE

\section{HENRY WARD RANGER, N.A.}

AND HIS COLLECTION OF WORKS

BY SOME OF HIS CONTEMPORARIES

TO BE SOLD AT UNRESTRICTED PUBLIC SALE

BY DIRECTION OF

MR. CHARLES HENRY PHELPS

AND

MR. WILLIAM MACBETH

EXECUTORS

ON THE EVENINGS HEREIN STATED

IN THE NEW ASSEMBLY ROOM OF

THE AMERICAN ART GALLERIES

MADISON SQUARE SOUTH, NEW YORK

THE SALE WILL BE CONDUC'TED BY

MR. THOMAS E. KIRBY

AND HIS ASSISTANT, MR. OTTO BERNET, OF THE

AMERICAN ART ASSOCIATION, MANAGERS NEW YORK CITY

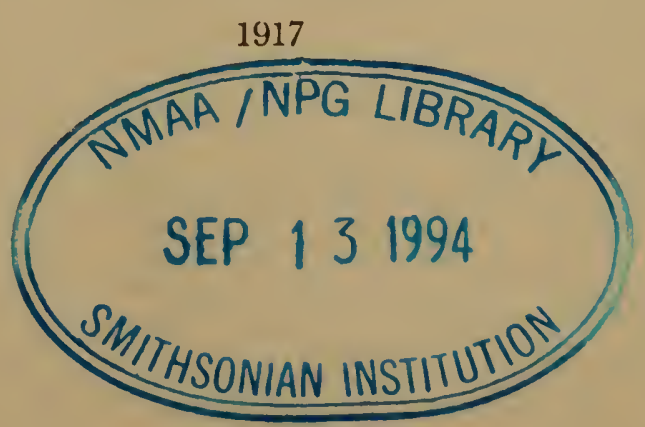


THE AMERICAN ART ASSOCIATION DESIGNS ITS CATALOGUES AND DIRECTS ALL DETAILS OF ILLUSTRATION

TEXT AND TYPOGRAPHY 


\section{PREFATORY NOTE}

The occasions have been rare when extensive public sale, have been made of the work of any single artist of note. We can most readily recall the names of Wyant, Inness and Twachtman, whose studio contents were sold after their death; the first named some twenty-five rears ago, the others following within a very few years. In each case surprise was expressed at the number of pictures left by these artists, the fact being overlooked that their work represented many years. This is equally true of the collection of pictures by Mr. Ranger here catalogued. For reasons best known to himself, almost every one of what we consider his best working years seems to have seen something reserved. Had he been aiming at leaving behind a chronological collection of his canvases for preservation in one group, he could hardly have chosen differently. The pictures now to be seen together for the last time doubtless give the opportunity Mr. Ranger desired to enable the public to make an estimate of his life work. It is true that to-day's estimate may not be the final one. It rarely happens that artists are fairly judged until time furnishes a proper perspective.

Up to within his last eight or ten years, Mr. Ranger was a fairly prolific painter. Gradually he tarried longer and longer orer each canvas, and was often heard to say, during the last few years, that he would be rery happy if he could produce each year four or five canrases that came near satisfying his critical estimate of his own work.

Only a few intimate friends, from time to time, saw the pictures of his last year grow under his hand. Many will surely be interested in seeing them now; - they are described 
in the catalogue, but will be readily recognized without written description.

In his chosen method of painting, Mr. Ranger always bore in mind time's effect on his pigments. He always declared that passing years, mellowing and ripening them, would greatly enhance the beauty of his pictures. That this prophecy has been abundantly fulfilled, his older canvases give ample proof.

It was Mr. Ranger's custom to make direct out-of-doors sketches for all his pictures; sometimes careful pencil studies, of which his note books are full, at other times free oil sketches on small academy boards or panels. From these he painted his larger pictures. The sketches that appealed to him most he occasionally took up again and in finishing them produced some of his most intimate, charming pictures. Modest in size and fine in quality, they will doubtless be much prized.

Wildiam Macbeth. 


\section{CONDITIONS OF SALE}

1. Any bid which is merely a nominal or fractional advance may be rejected by the auctioneer, if, in his judgment, such bid would be likely to affect the sale injuriously.

2. The highest bidder shall be the buyer, and if any dispute arise between two or more bidders, the auctioneer shall either decide the same or put up for re-sale the lot so in dispute.

3. Payment shall be made of all or such part of the purchase money as may be required, and the names and addresses of the purchasers shall be given immediately on the sale of every lot, in default of which the lot so purchased shall be immediately put up again and re-sold.

Payment of that part of the purchase money not made at the time of sale shall be made within ten days thereafter, in default of which the undersigned may either continue to hold the lots at the risk of the purchaser and take such action as may be necessary for the enforcement of the sale, or may at public or private sale, and without other than this notice, re-sell the lots for the benefit of such purchaser, and the deficiency (if any) arising from such re-sale shall be a charge against such purchaser.

4. Delivery of any purchase will be made only upon payment of the total amount due for all purchases at the sale.

Deliveries will be made on sales days between the hours of 9 A. M. and 1 P. M., and on other days-except holidaysbetween the hours of $9 \mathrm{~A}$. MI. and $5 \mathrm{P}$. M.

Delivery of any purchase will be made only at the American Art Galleries, or other place of sale, as the case may be, and only on presenting the bill of purchase.

Delivery may be made, at the discretion of the Association, of any purchase during the session of the sale at which it was sold. 
5. Shipping, boxing or wrapping of purchases is a business in which the Association is in no wise engaged, and will not be performed by the Association for purchasers. The Association will, however, afford to purchasers every facility for employing at current and reasonable rates carriers and packers; doing so, howerer, without any assumption of responsibility on its part for the acts and charges of the parties engaged for such service.

6. Storage of any purchase shall be at the sole risk of the purchaser. Title passes upon the fall of the auctioneer's hammer, and thereafter, while the Association will exercise due caution in caring for and delivering such purchase, it will not hold itself responsible if such purchase be lost, stolen, damaged or destroyed.

Storage charges will be made upon all purchases not removed within ten days from the date of the sale thereof.

7. Guarantee is not made either by the owner or the Association of the correctness of the description, genuineness or authenticity of any lot, and no sale will be set aside on account of any incorrectness, error of catologuing, or any imperfection not noted. Every lot is on public exhibition one or more days prior to its sale, after which it is sold "as is" and without recourse.

The Association exercises great care to catalogue every lot correctly, and will give consideration to the opinion of any trustworthy expert to the effect that any lot has been incorrectly catalogued, and, in its judgment, may either sell the lot as catalogued or make mention of the opinion of such expert, who thereby would become responsible for such damage as might result were his opinion without proper foundation.

\section{AMERICAN ART ASSOCIATION,}

American Art Galleries,

Madison Square South,

New York City. 


\section{CATALOGUE}

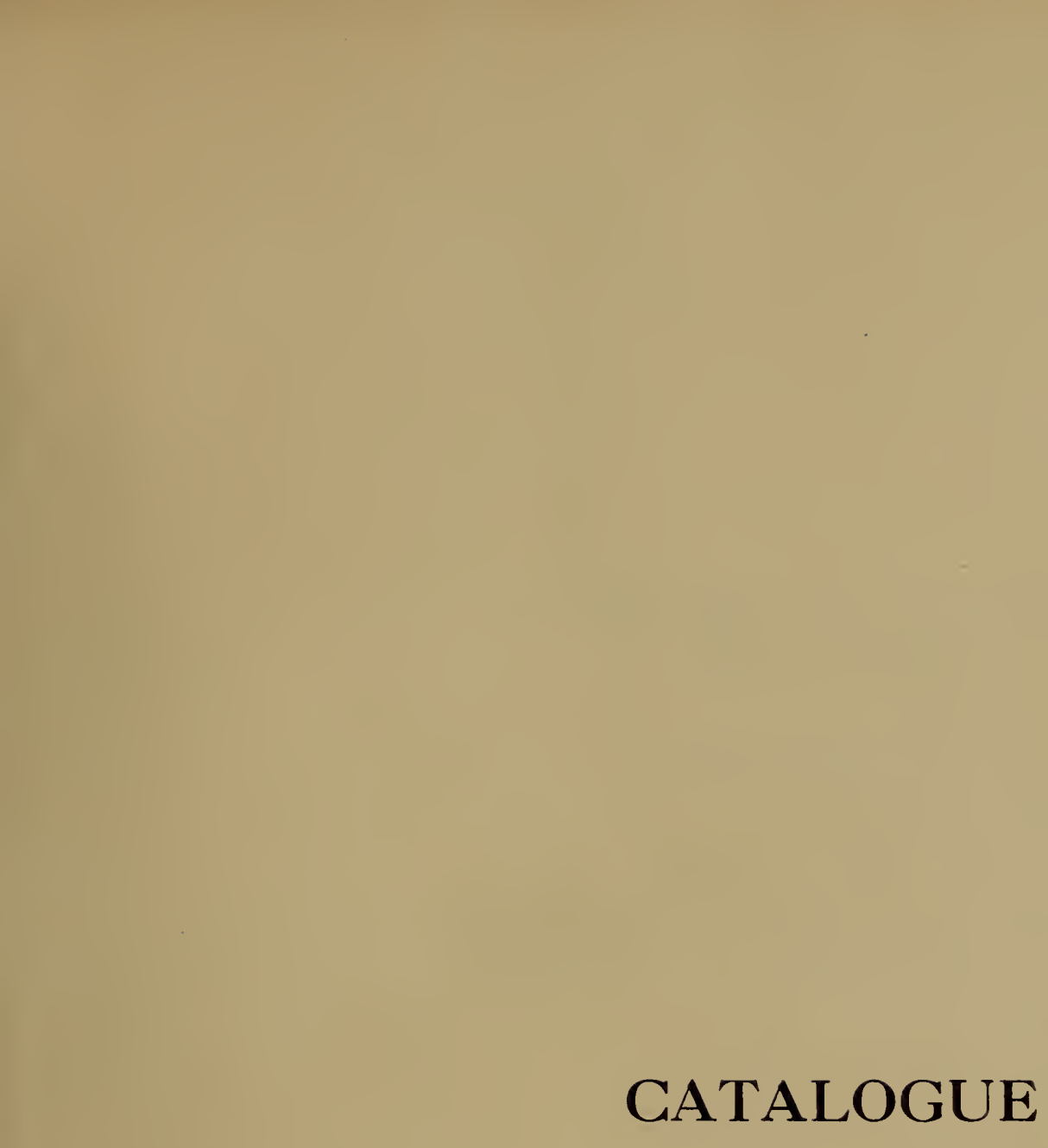



No. 3

\section{RALPH ALBERT BLAKELOCK, N.A.}

AMERICAN: 1847 -

\section{LANDSCAPE}

Height, $51 / 2$ inches; length, 101/2 inches

A view through a glade between two clumps of trees showing a lake, distant hills, and a characteristic Blakelock blue and white sky.

Signed at the lower left.

\section{No. 4 \\ WILLIAM GEDNEY BUNCE, N.A. \\ A Miericax : $1840-1916$}

\section{ST. GEORGIO, VENICE}

Panel: Height, 13 inches; width, 81/2 inches

A sкетсн in pale tones of the famous Venetian church rising from the water in which its bulk is reflected brokenly. On the back of the panel is a rough sketch of fishing boats and the title of this picture in the artist's hand with his signature. making an interesting possession. 
No. 5

\section{CHARLES FRANÇOIS DAUBIGNY (ATTRIBUTED) \\ FRENCH: $1817-1878$}

\section{EVENING SCENE}

Panel: Height, 81/2 inches; length, 15 inches

A Low-toned view of a river, with its farther bank and the clump of trees at the right deep in shadow. The sky is filled with the last light of the sinking sun, reflections of which gleam on the water in the foreground where cows are drinking.

Signed at the lower left.

No. 6

\section{WILLIAM GEDNEY BUNCE, N.A. \\ A Merican : $18+0-1916$ \\ $A T A N C H O R$}

Panel: Height, 81/2 inches; length, 13 inches

A TRAMP steamer of an old-fashioned type lies at her mooring in Venetian waters. Native boats are seen in the distance and gray clouds partly obscure the blue sky.

Signed at the lower left, W. Gensex Buxce, Vexice. 
No. 7

J. FRANCIS MURPHY, N.A.

Anericax: 1853

\section{GUSTY WEATHER}

Water Color: Height, 12 inches; width, 9 inches

BY the side of a stream in a green meadow stands a clump of trees from which the leaves are whirling away under the strong wind indicated by the stormy sky. In the distance is seen another group of trees in autumnal coloring. A gift from Mr. Murphy to Mr. Ranger as the dedication shows.

Signed at the lower left.

At the lower right, "To my friend Ranger, Mar. 23, '86."

No. 8

ARTHUR WARDLE

Exglish : Contemporary

LIONS-MOONLIGHT

Pastel: Height, $91 / 2$ inches; length, 131/2 inches

A CharaCteristic study, by this distinguished British animal painter, of two lions and a lioness, prowling across the desert beneath a clear blue tropical sky.

Signed at the lower right. 
No. 9

\section{WILLIAM GEDNEY BUNCE, N.A.}

Anericax: $1840-1916$

\section{MARINE-VENICE}

Panel: Height, 81/2 inches; length, 13 inches

ONE of this artist's favorite compositions. Venetian fishing boats with high-peaked lugsails stained pale yellow or red lying motionless on the calm waters of the Adriatic.

Signed at the lower left, W. G. B., Vexice.

No. 10

WILLIAM HENRY HOWE, N.A.

A jiericas: $1846-$

\section{BLACK AND WHITE COWS}

Panel: Height, 10 inches; length, 14 inches

A DROYE of black and white cows are seen standing and grazing in a flat green meadow. In the background at the right is an old windmill and two others are seen on the horizon. A personal souvenir of two artists.

Sigued at the lower right.

Dedicated at left, " $\Lambda$ mon ami, H. W. Ranger." 
No. 14

f O'HERMAN FREDERIK KAREL TEN KATE

\section{AN OLD STREET IN ROUEN \\ Water Color: Height, 11 inches; length, 14 inches}

A COLORFUL view of an old street in Rouen with peasants in blue smocks, the wall at the right corered with posters. An arched passageway gives a riew beyond of houses and a glint of blue and white sky.

Signed at the lower left, and dated Rovex, '85.

No. 15

\section{WILLIAM GEDNEY BUNCE, N.A.}

Astericax: $1840-1916$

\section{THE MOORING BUOY}

Panel: Height, 1t inches; length, 17 inches

ONe of the great red mooring buoys that are "laid down" in foreign harbors is the chief object in this picture. Its worn red-toned bulk floats in the calm water of the Adriatic, the tide making a ripple along its side. In the distance are seen white-sailed feluccas and the smoke of a steamer.

signed at the lower right, W. Gedxer Buxce, Vexice. 


\section{No. 16 \\ CARLETON IVIGGINS, N.A. \\ Americax: 1848- \\ COWS}

Panel: Height, 13 inches; length, 18 inches

Ix the foreground two cows are standing in profile and beyond at the left another one is lying on the grass of the meadow. Strong sunlight floods the whole scene from out of a clear blue sky.

Signed at the lower left.

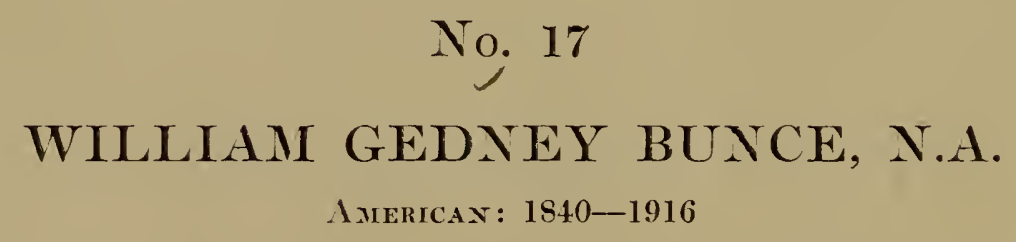

MARINE

Prenel: Height, 14 inches: length, 17 inches.

FLAT mud banks stretch away at the left of the picture, calm water filling all the rest of the view to the horizon. A redsailed felucca and the smoke of a distant steamer make strong notes of color against the blue sky that is obscured by pinkish gray clouds above.

Signed at the loacer left. 
No. 18

\section{J. F. MILLE'T}

(ATTRIBUTED)

FREACH: : $1814-1875$

\section{HEAD OF A BOY}

Height, 18 inches; reirlth, 15 inches

THE head and bust of a typical ruddy-cheeked blond French peasant lad. He is looking upward and toward the right, the forefinger of his left hand held against his lower lip suggesting wonderment rather than surprise. In his right hand he holds an apple against the red kerchief tied loosely around his throat.

Signed at the lower right, J. F. M.

No. 19

\section{LOUIS ARTAN}

BELGIAN : $1837-1890$

\section{DUTCH RIVER SCENE}

Height, 11 inches; length, 25 inches

BENEATH the lowering skies of Holland a river washes up into a long streak of foam on the flat shore in the foreground. A town spreads along the opposite bank with windmills and church spires breaking the low line of red and gray-walled houses. At the right is seen a Dutch river boat with a tinted lugsail. 


\section{PAINTINGS BY THE LATE HENRY. WARD RANGER, N.A.}

Catalogue Nos. 20 to 83 , inclusive

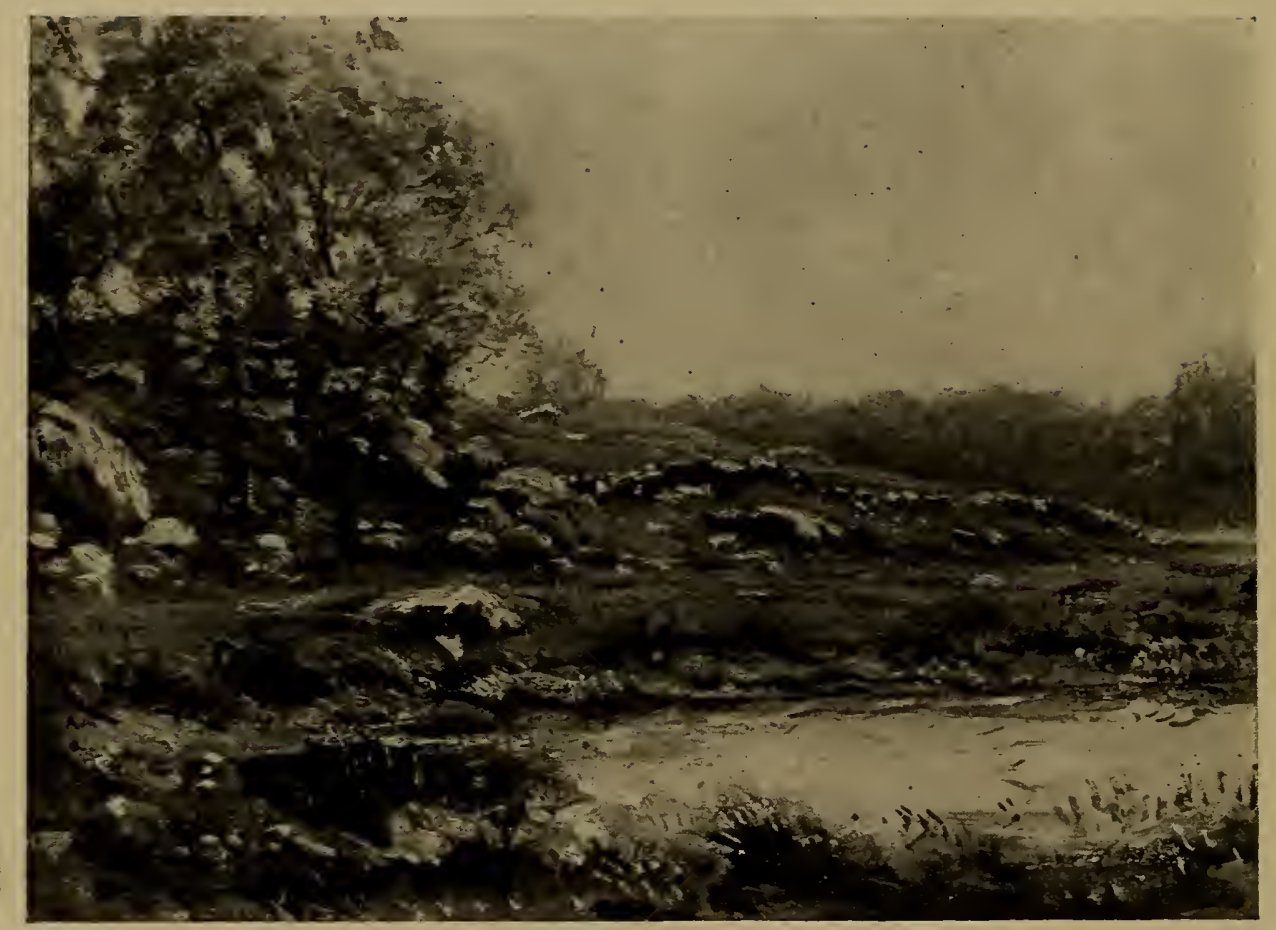

No. 20

\section{HENRY WARD RANGER, N.A. \\ American : $1858-1916$ \\ LANDSCAPE}

Panel: Height, 12 inches; length, 16 inches

From a little salt water cove a low hillside rises from right to left. At the right is a mass of trees and at the left two trees rise out of the green and russet slope amidst a mass of huge gray rocks. 


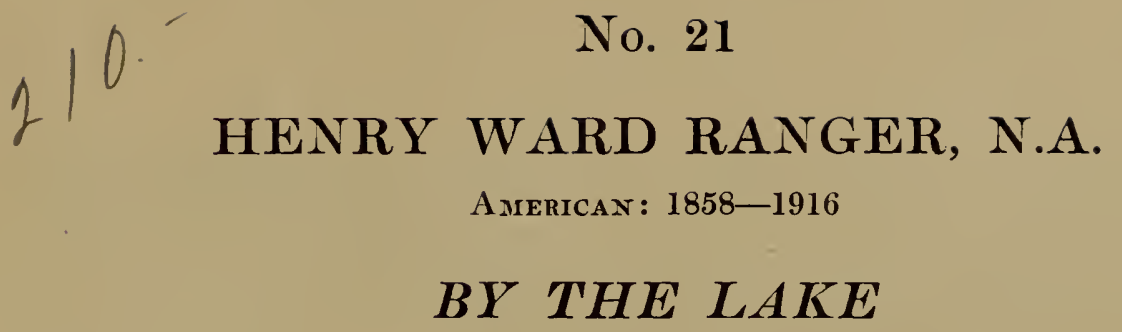

Millboard: Height, 12 inches; length, 14 inches

At the edge of a lake on which is seen a man in a fishing punt rises a group of trees touched with autumn's red. Old gray barns are at the left and at the right are two red-and-whitewalled houses. Against the deep blue sky float a few white clouds.

Signed at the lower left, and dated.

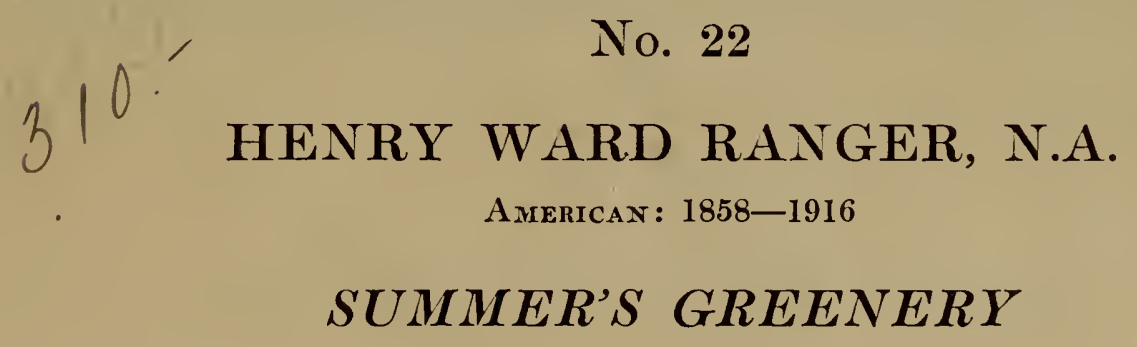

Millboard: Height, 12 inches; length, 14 inches

In the foreground a brook winds through a rich green meadow behind which is seen a line of slender trees marking the edge of a barnyard. The barn and the outhouses are at the foot of a hill that slopes back to meet a blue sky dotted with white clouds. At the left is a dark green tree and at the right a grove of trees rises up to the top of the picture.

Signed and dated at the low'er left. 


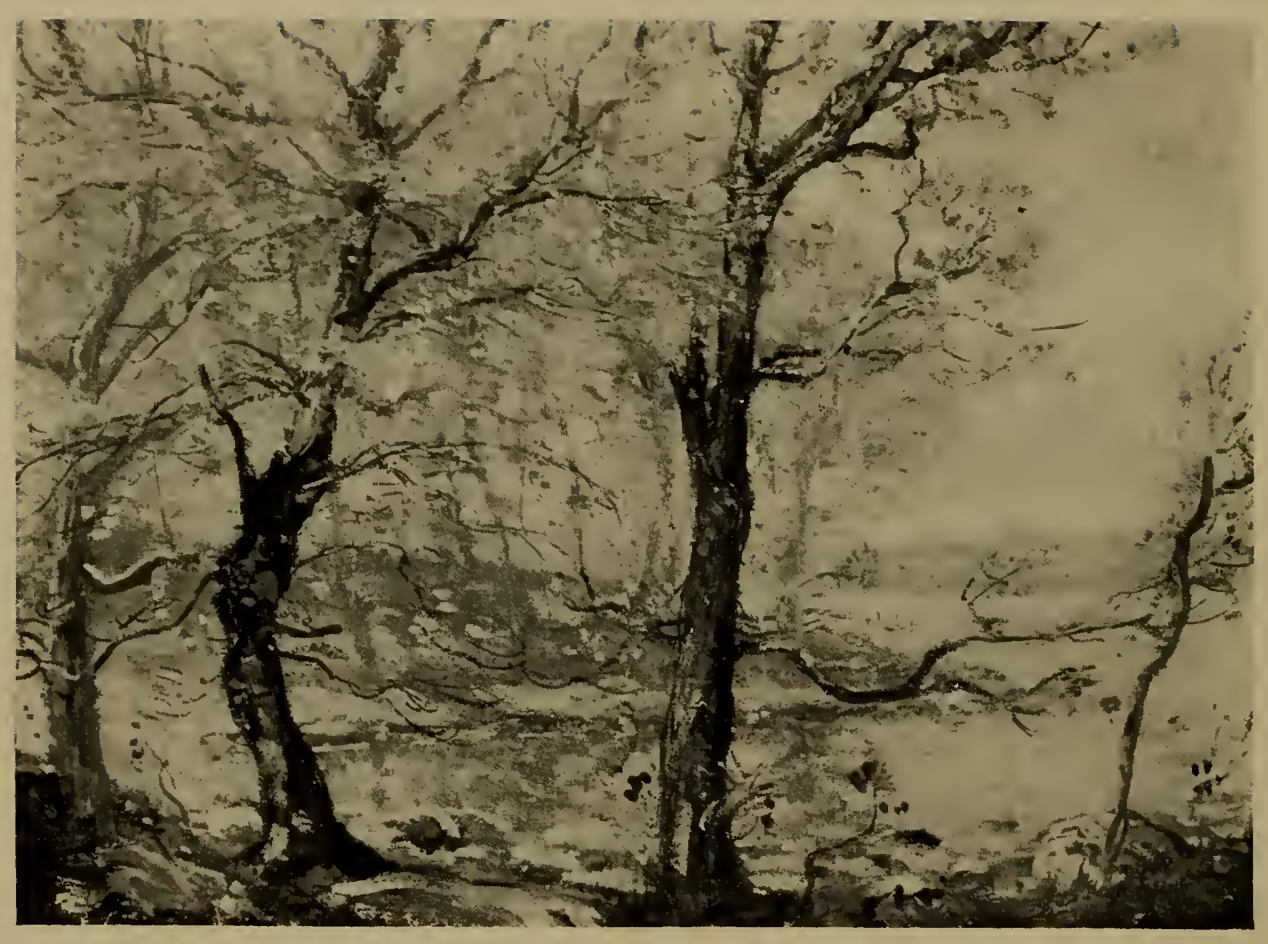

No. 23

\section{HENRY WARD RANGER, N.A. \\ American: $1858-1916$}

\section{- THREE TREES}

Panel: Height, 12 inches; length, 16 inches

Br the bank of a river stand three trees at the edge of a little cove beyond which the spectator sees a tree-covered point of land and rising ground on the stream's opposite shore. 


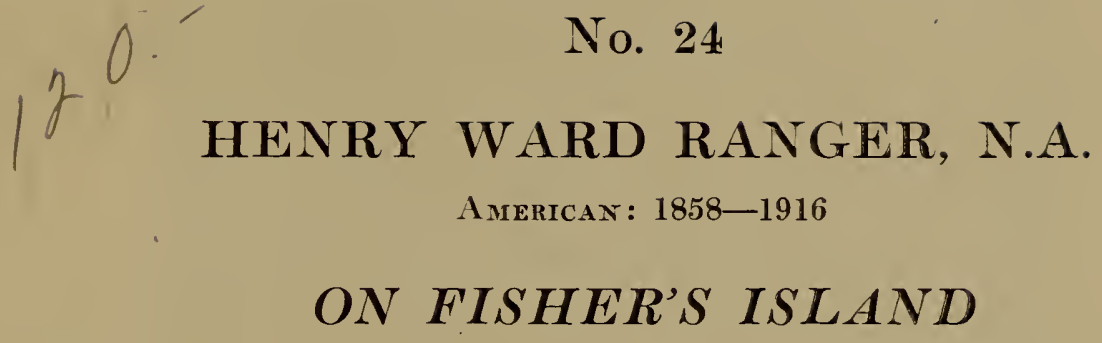

Panel: Height, 12 inches; length, 16 inches

Benind a steep-banked cove into which the blue water churns up in white froth-rises one of the familiar grass-grown hills of Fisher's Island. In the foreground is meadow land and beyond the seaward edge of the hill another height shows at the left.

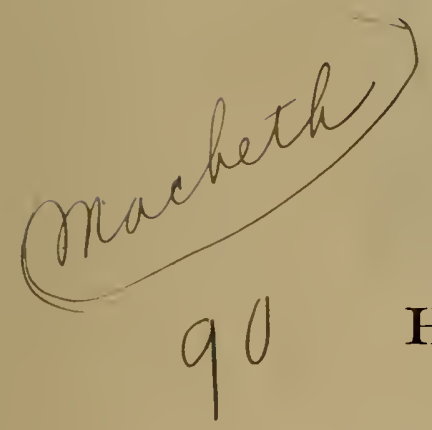

No. 25

HENRY WARD RANGER, N.A.

American : $1858-1916$

\section{BRE AKING WAVES}

Panel: Height, 12 inches; length, 16 inches

GEeNish blue water breaks into whitecapped wares over a bar forming a long line across the empty sea. Tumbling cloud masses drive across the sky that deepens from pale blue at the horizon to dark blue at the top of the picture. 


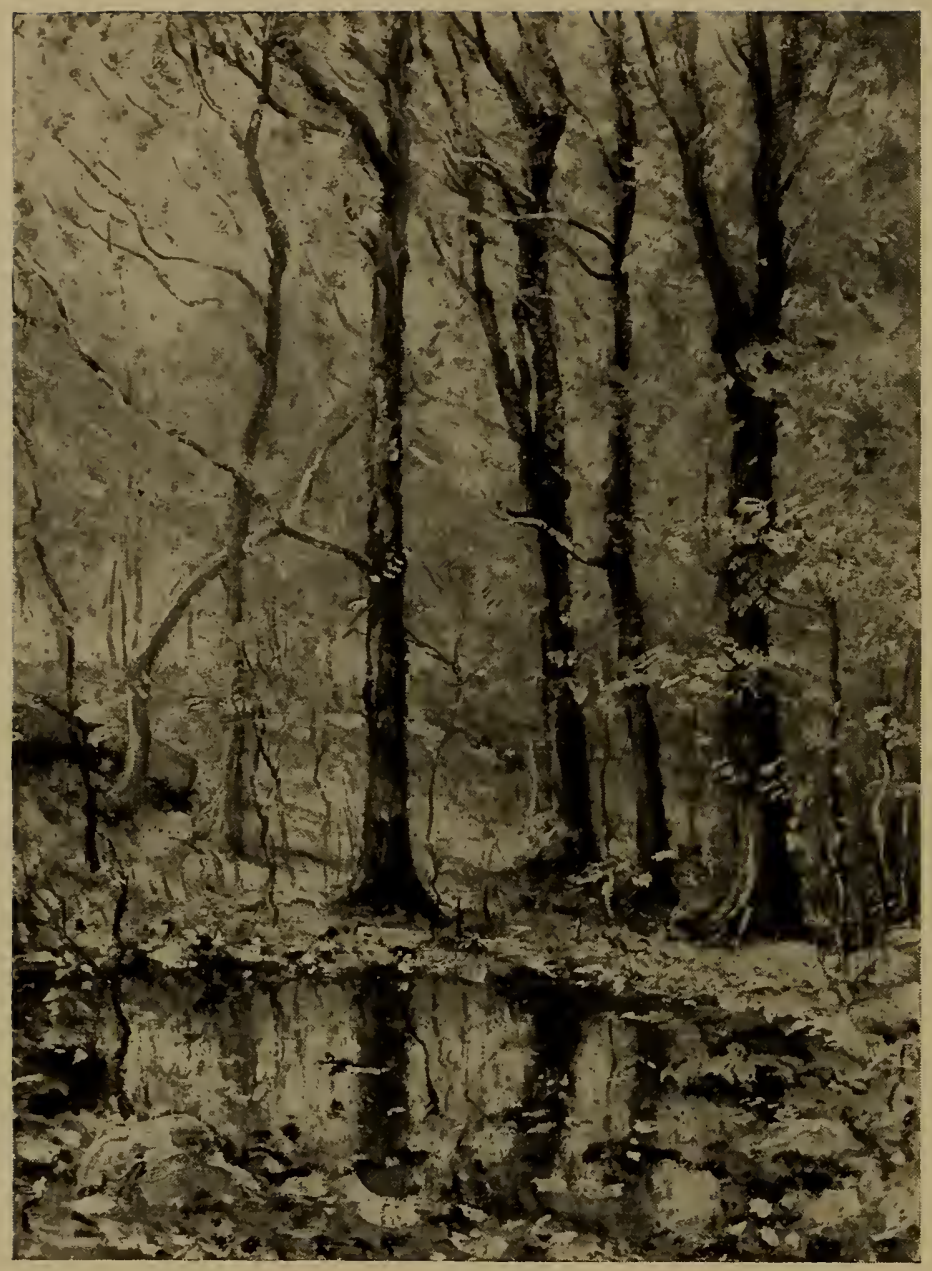

No. 26

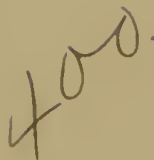

HENRY WARD RANGER, N.A.

Americas: 1858-1916

\section{WOODLAND-GRAY AND YELLOW}

Millboard: Height, 16 inches; rcidth, 12 inches

Is the foreground a tiny pool reflects the gray tree trunks rising behind it on the branches of which are left some yellow leaves. Leaves of the same hue cover the ground and in the background a pale blue sky shows through the branches. 
No. 27

HENRY WARD RANGER, N.A.

American : 1858-1916

\section{WOODS IN SPRINGTIME}

Panel: Height, 12 inches; length, 16 inches

IN a bit of woodland where gray bowlders lie scattered on a valley's slope two trees stand almost in line and form the chief note in the bright springtime scene. A man in red shirt and white hat stands by the trees and behind him is a dense thicket.

No. 28

HENRY WARD RANGER, N.A.

American : $1858-1916$

\section{WIDE-SPREADING BRANCHES}

Millboard: Height, 12 inches; length, 16 inches

The low underspreading branches of an old tree form a twotoned pattern of color against a pale blue sky. It rises out of a green pasture beside a low stone wall and beyond is a dim prospect of trees and distant hills. 


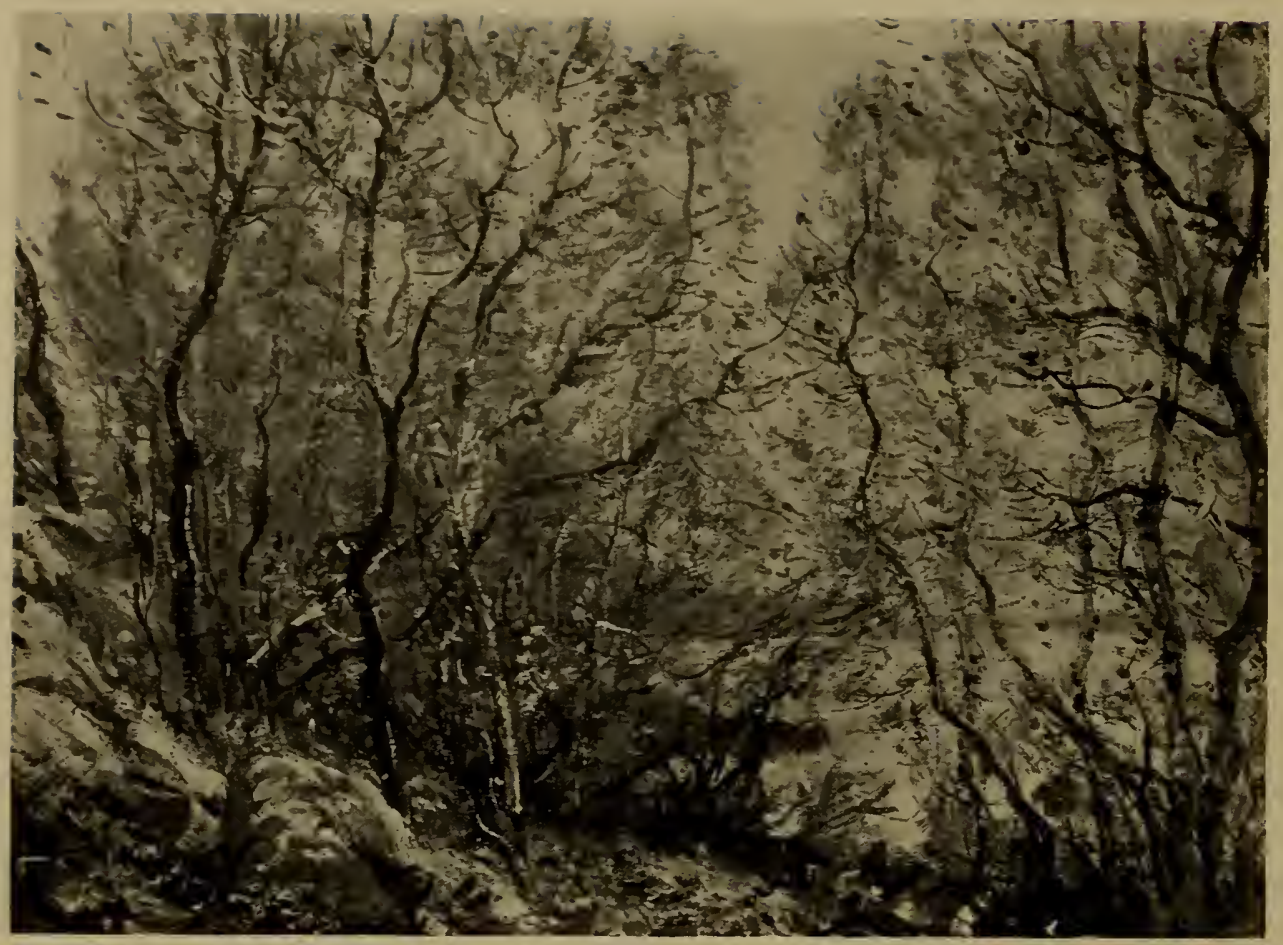

No. 29

HENRY WARD RANGER, N.A.

Anericax: $1858-1916$

\section{A SCREEN OF TREES}

Panel: Height, 12 inches; length, 16 inches

GRAY rocks rise up at the left and trees stand along the foreshore, making, with their branches, a screen through which the eye searches out a stretch of pale blue water and a sky of the same hue. 
No. 30

HENRY WARD RANGER, N.A.

Aniricax: $18.58-1916$

\section{A FISHER'S ISLAND COVE}

Panel: Height, 12 inches; length, 16 inches

'THis study of one of Mr. Ranger's favorite coast scenes shows an indentation of the shore with the blue water ruming up on a hard sand beach. The eroded end of a green hill fills the right of the canvas, while beyond is the line of hill that marks the other boundary of the cove. A loosely brushed in whitish blue sky runs up to the top of the picture.

Signed at the lower left.

No. 31

HENRY WARD RANGER, N.A.

AMERICAN : $1858-1916$

ACROSS THE VALLEY

Millboard: Height, 12 inches; length, 16 inches:

From the edge of a natural terrace the eye is carried over a line of tree tops to a valley dotted with farmhouses. Beyond is another line of trees and under a gray sky one looks farther on to a faint line of hills. 


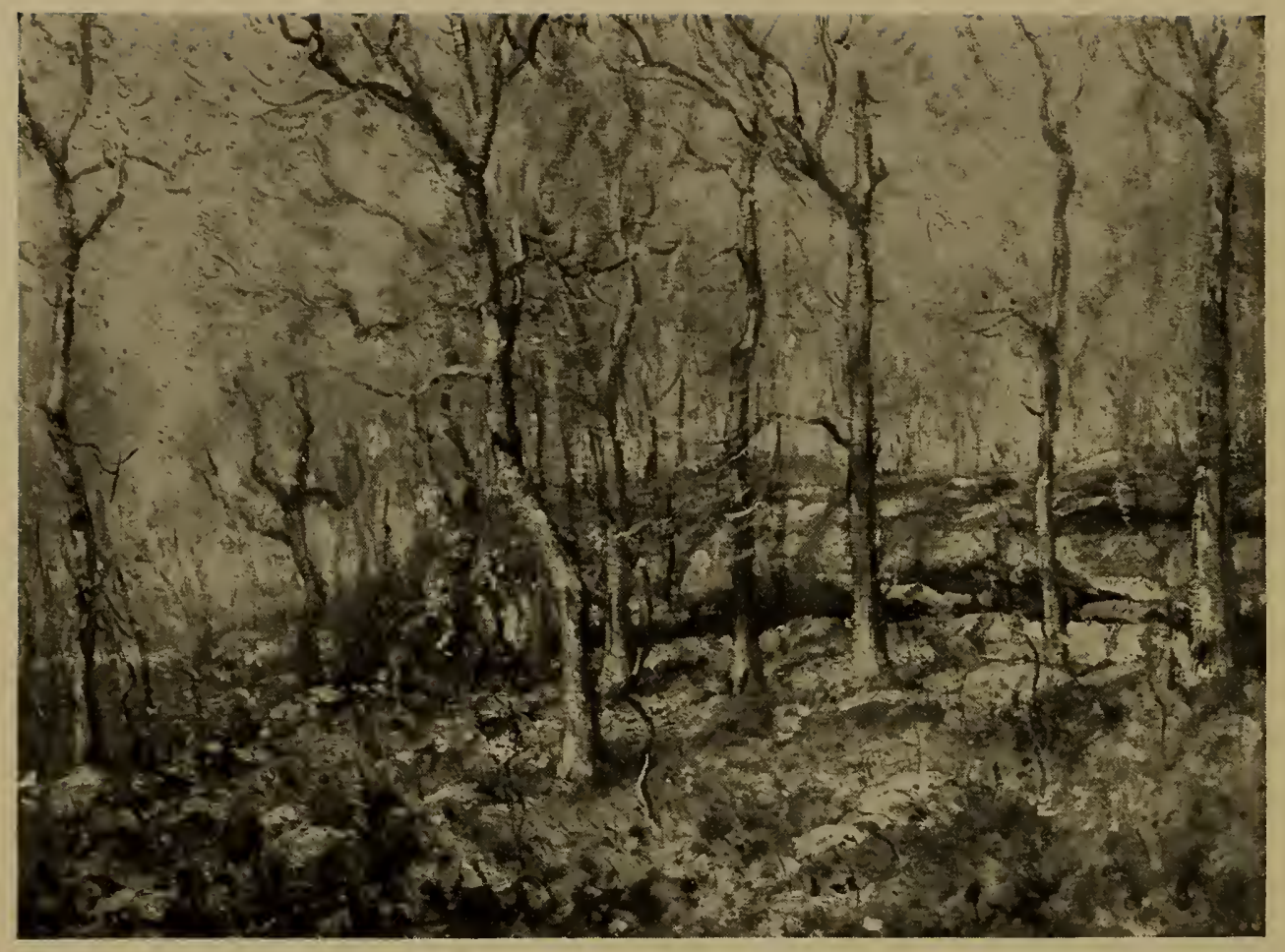

No. 32

HENRY WARD RANGER, N.A.

American : $1858-1916$

\section{A LEDGE OF ROCKS}

Panel: Height, 12 inches; length, 16 inches

Through bare-branched trees in the strong sunlight one sees an outcropping ledge of lichen-covered rocks barred with the sharp shadows of the tree trunks. Above, and to the right, is a natural terrace, while to the left one looks through the trees into the blue distance.

Signed at the lower left and dated. 


\section{HENRY WARD RANGER, N.A.}

American : $1858-1916$

\section{$M A R I N E$}

Panel: Height, 12 inches; length, 16 inches

ON a calm sea four fishing boats are seen at anchor, several old mooring posts making definite notes of color near at hand. Lazy white clouds float overhead in a windless sky.

Signed at the lower left.

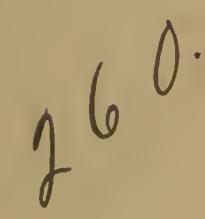

No. 34

HENRY WARD RANGER, N.A.

AMerican : 1858-1916

\section{WOOD INTERIOR}

Millboard: Height, 12 inches; length, 16 inches

Is the shadow of a grove the outcropping rocks and tree boles take on a bluish gray tone. Beyond, in a clearing, the sunlight marks a band of light on the earth that also illumines the trees beyond, above which is caught glimpses of a bright blue sky.

Signed at the lower left. 

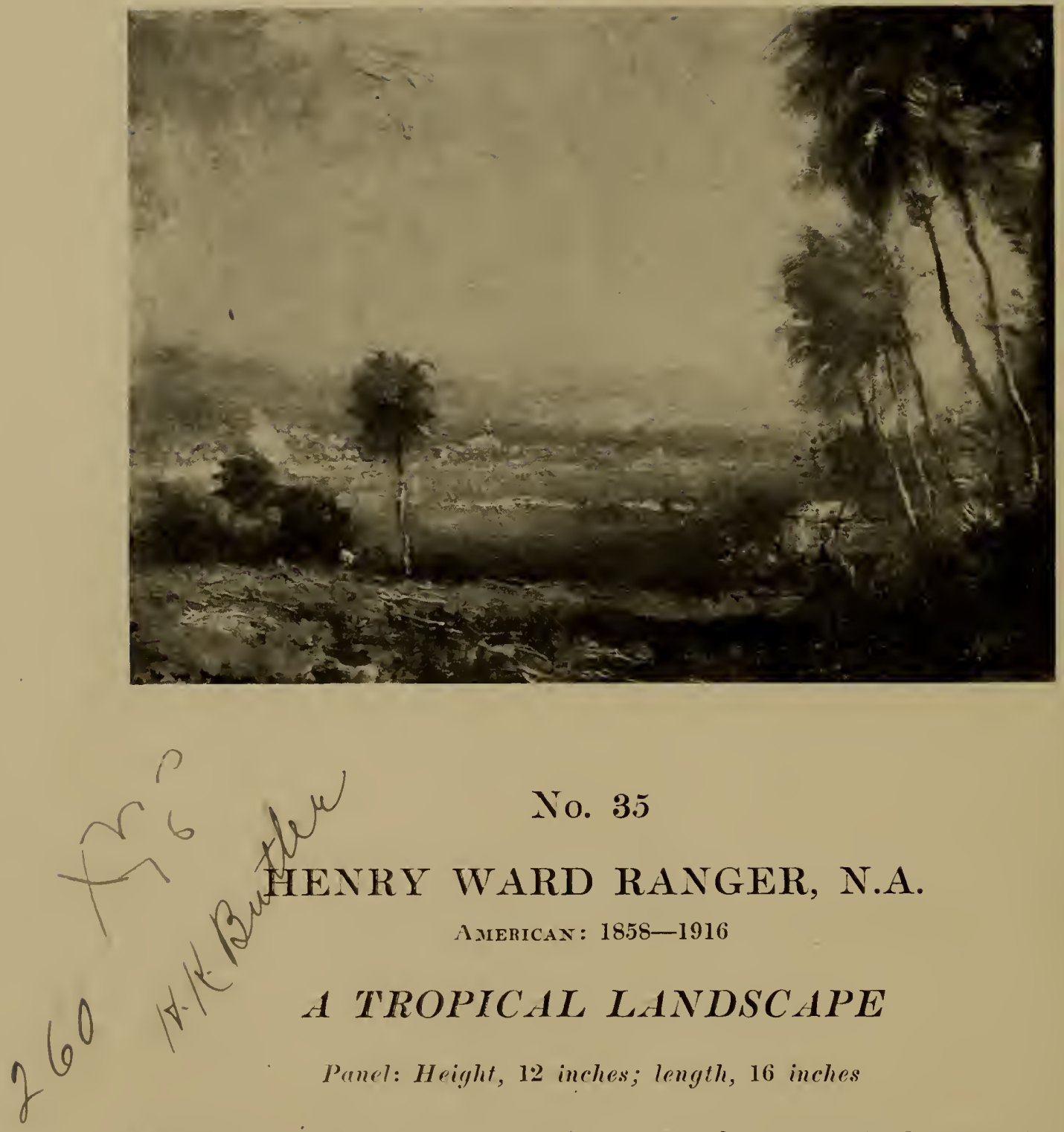

Probably a scene in Porto Rico. Feathery tropical trees rise up at the right of the picture above a white native house. A clump of trees and a single palm are at the left and across a flat plain are seen houses and blue hills. Over the whole scene is one of the rain-laden cloud masses that discharge their contents over the countryside at regular and irritating intervals. 


\section{No. 36 \\ HENRY WARD RANGER, N.A. \\ AMERICAN : $1858-1916$ \\ A FISHERMAN'S BOAT}

Millboard: Height, 12 inches; length, 16 inches

A sympony in blue and white and green is this lovely 'longshore picture. Near at hand on the still water floats a fisherman's powerboat moored. to a post. Across the water is seen a low shore line, dunes for the most part with rows of trees at the right.

Signed at the lower left, and dated 1906

No. 37

310

\section{HENRY IVARD RANGER, N.A.}

Imericas: $1858-1916$

\section{WOODLAND}

Panel: Height, 12 inches; length, 16 inches

BARE second growth trees rise out of the rock strewn earth. Cutting across the center of the picture is a stone wall behind which is seen a thick growth of trees, all under a pale blue sky seen through a haze of white clouds. 


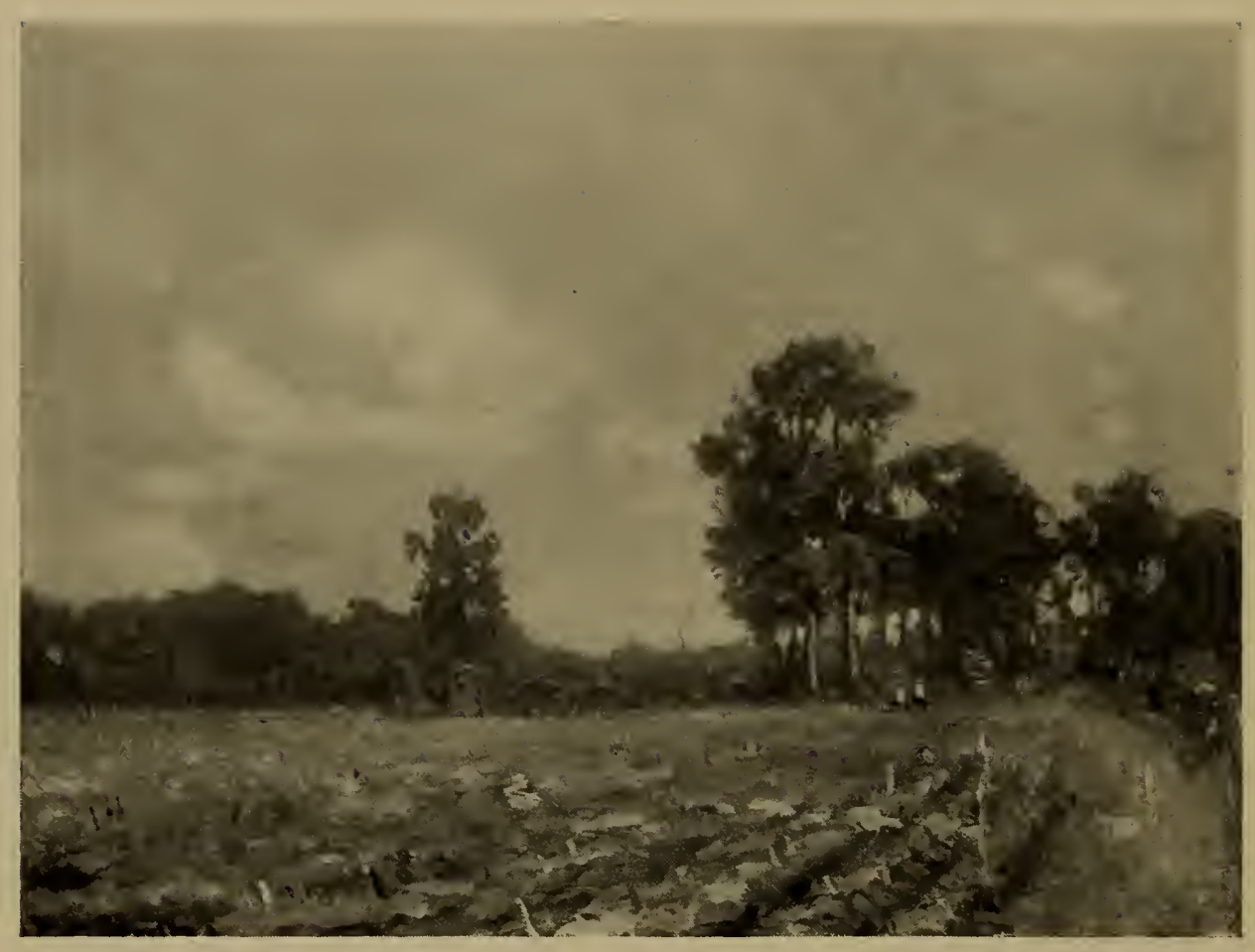

No. 38

\section{HENRY WARD RANGER, N.A.}

A Mericay : 1858-1916

\section{A WINDY SKY}

Millboard: Height, 12 inches; length, 16 inches

Across a pale blue sky big and little masses of cumulus clouds are driven by a high wind that wreaks its will on flying leaves. In the foreground is a ploughed field of rich earth and in the middle distance are seen two figures with a clump of shapely trees behind them at the right, while at the left one tree spires above a distant grove rich in the greenery of late summertime. 
No. 39

HENRY WARD RANGER, N.A.

American : $1858-1916$

\section{RUSSET AND BLUE}

Millboard: Height, 12 inches; length, 16 inches

THE center of the picture is almost filled with a fine oak tree, the leaves of which are turned to a russet hue. Overhead is a superb blue sky with white clouds floating across it and in the background is a mass of trees giving glimpses of the sky beyond.

Signed lower' left, and dated '97.

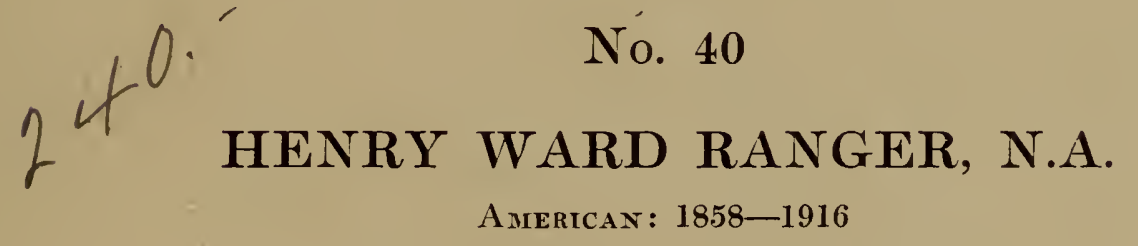

\section{LATE AUTUMN}

Millboard: Height, 12 inches; length, 16 inches

A Few trees, silver gray as to trunks, pale russet as to foliage, are grouped in the center and right of the picture under a greenish blue sky veiled by faint gray clouds. A green and brown pasture is in the foreground and a pile of boulders is massed beneath the trees. 
No. 41

\section{HENRY WARD RANGER, N.A. \\ Anericay : $1858-1916$ \\ ROCKS AND SEA}

Panel: Height, 12 inches; length, 16 inche.

Soft masses of cumulus clouds drive across a blue sky beneath which is seen a broad expanse of green blue water touched here and there with white caps. From the rock-strewn beach in the foreground one looks across to a distant shore with suggestions of houses and sails and low hills.

Signed at the lower left.

No. 42

\section{HENRY WARD RANGER, N.A. \\ AMERICAN: $1858-1916$}

SEASHORE MEADOWS

Millboard: Height, 12 inches; length, 16 inches

MiLes of slightly rolling meadow land such as one sees along our Eastern seashore stretches away from the eye, dotted with rocks, bushes, stunted trees and pools of water. Two figures are at the right and overhead is a lovely blue sky splashed with great cloud masses of white and gray. 


\title{
COTTAGE AND TREES
}

Height, 18 inches; length, 26 inches

A whITE-WALLED red-roofed cottage is partly seen in the background behind a line of willows. The sunlight brightens its wall and falls on the blossoming trees in the dooryard. A dense mass of trees rises behind at the right, and at the left is a prospect of flat tilled fields. A man on a white horse stands in the shadow of the willows and overhead is a bright blue sky dotted with sunlit fleecy clouds.

Signed at the lower left.

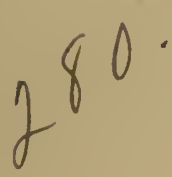

\author{
No. 44 \\ HENRY WARD RANGER, N.A. \\ American : 1858-1916
}

\section{HOMEWARD BOUND}

Height, 18 inches; length, 26 inches

Across a lonely moor a shepherd walks with his sheep and dog, the moonlight making the backs of the sheep gleam with high lights. The blue of the sky is reflected in a pool of water and the full moon and bright stars shine out of a sky that is partly obscured by darkling clouds. 

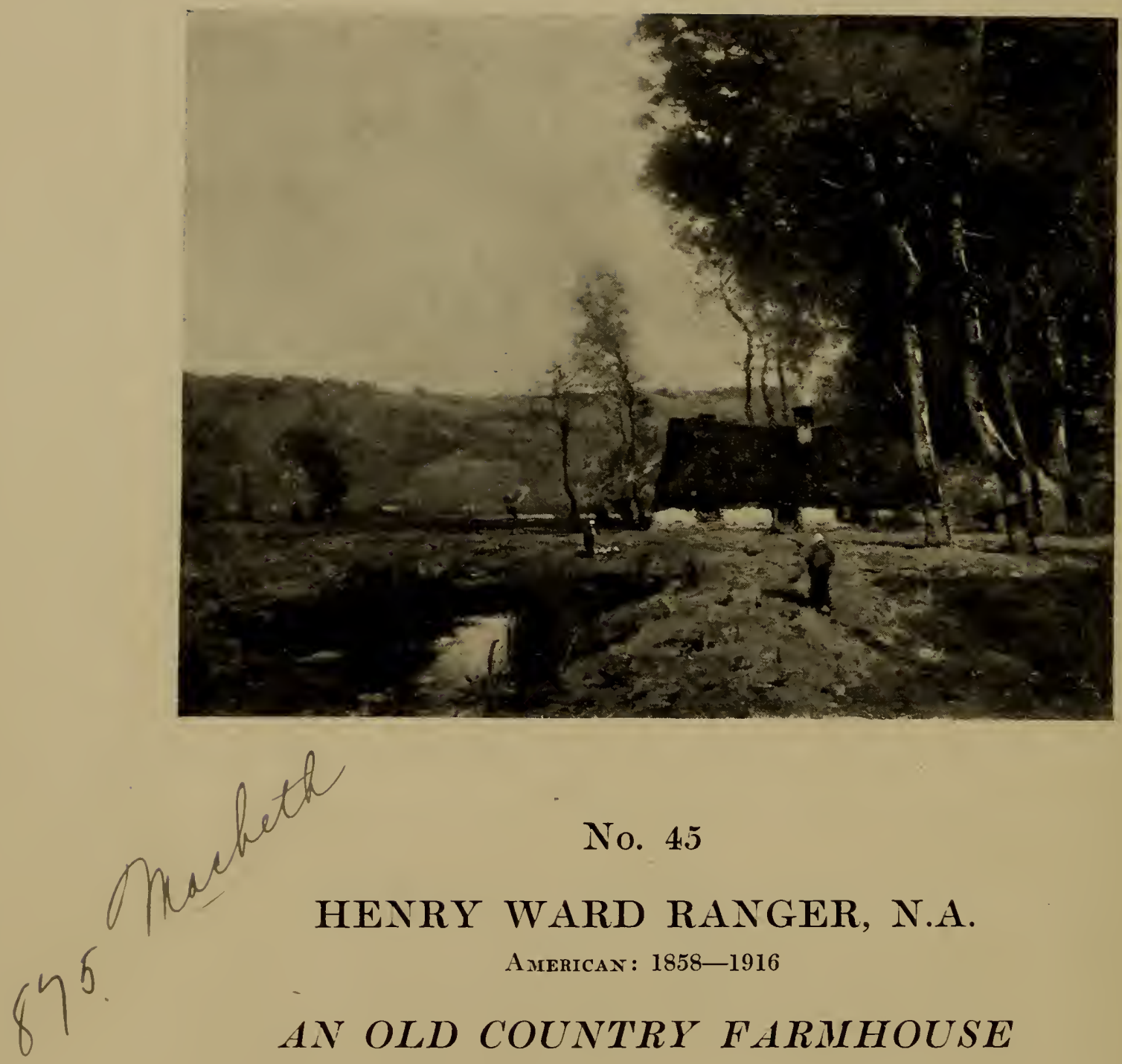

Height, 18 inches; length, 24 inches

Alovg a lane that runs to a white-walled, steep-roofed farmhouse a peasant woman is walking homeward and in the lush green meadow is seen another woman with a flock of geese. Smoke rises from the chimney of the farmhouse against a dense grove of tall trees at the right of the picture, while beyond the meadow in the background runs a line of green hills, all under a tender early evening sky.

Signed at the lower left. 
No. 46

\section{HENRY WARD RANGER, N.A.}

American : 1858-1916

\section{IN THE WOODS}

Height, 18 inches; length, 26 inches

Carpeted with red and russet leaves and dotted with rocks, the earth stretches away from the eye amongst a growth of trees. Their foliage is turned red and yellow and the mass of leafage in the middle distance glows in the hot light of the unseen sun.

Signed at the lower left, and dated 1900

No. 47

HENRY WARD RANGER, N.A.

American : $1858-1916$

\section{HOLLAND LANDSCAPE}

Height, 18 inches; length, 26 inches

A LOW-WALLED farmhouse is at the right of the picture with two green trees toward the center, in a rich grass meadow. Other houses are seen at the left in a grove of trees and in the foreground is a narrow stream on which is a man in a punt tending a brush fire. Over the scene is a characteristic Low Country sky of gray and white clouds.

Signed at the lower left. 

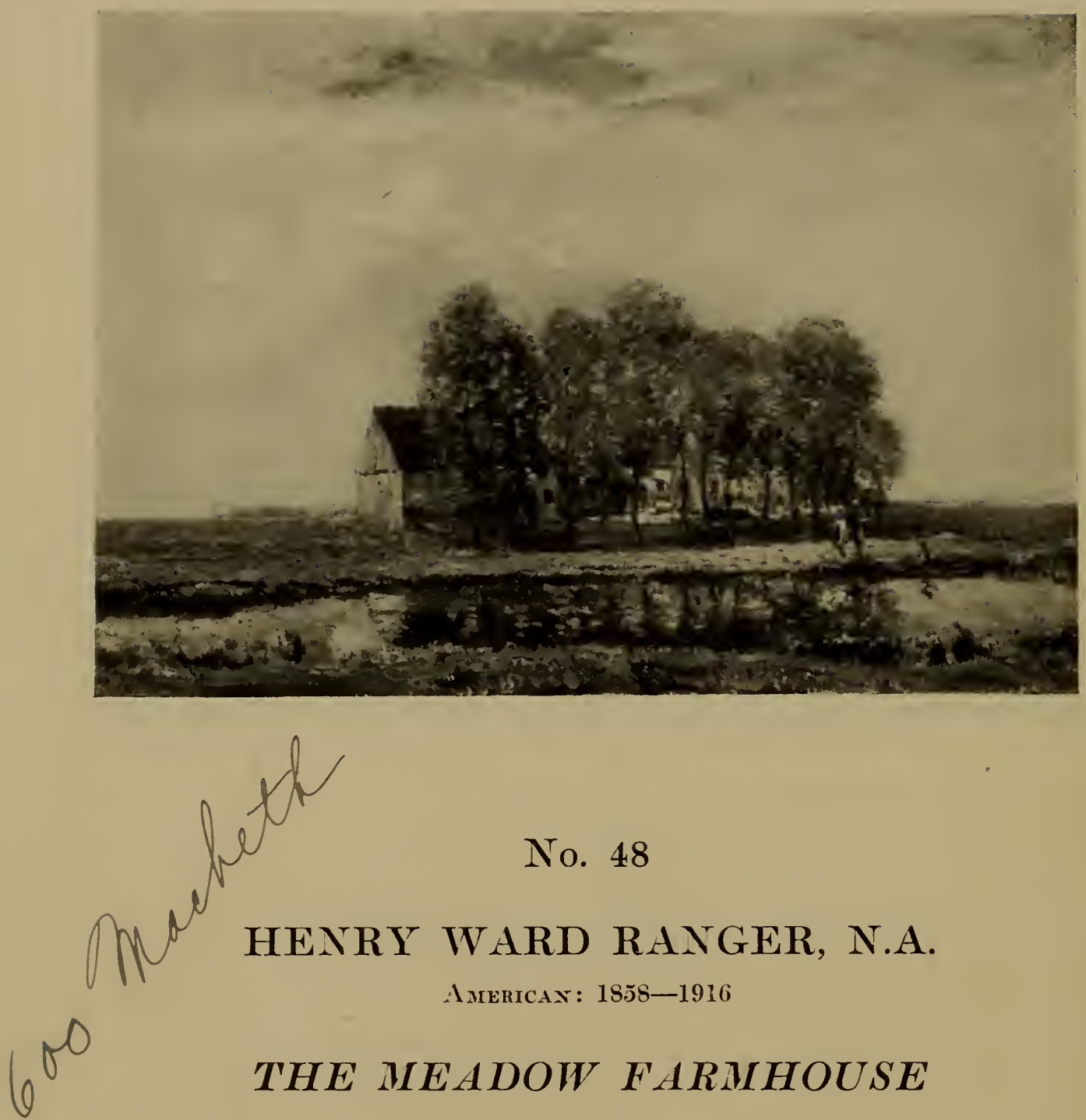

No. 48

THE MEADOW FARMHOUSE

Height, 18 inches; length, 26 inches

SET at the waterside edge of a wide expanse of meadows is a white farmhouse with its attendant barns and outhouses partly screened from view by the line of thick growing trees before it. A man is in a skiff at the right and on the bank by him another in a red shirt sits on a white horse. Overhead is a brilliant cloud-flecked sky.

Signed at the lower left, and dated'96. 
No. 49

\section{$36^{0}$ HENRY WARD RANGER, N.A. \\ Amertcan : 1858-1916}

\section{A COUNTRY ROAD}

Height, 18 inches; length, 26 inches

From the foreground a country road runs directly away from the spectator curving slightly to the left in the distance. A man in a red shirt walks along at the right and on either side are white and red houses. Trees line the road and masses of them are seen in the distance.

Signed lower left and dated.

No. 50

HENRY WARD RANGER, N.A.

American: 1858-1916

\section{FARMHOUSE AND WILLOWS}

Height, 18 inches; length, 26 inches

Against a hillside crowned by a crude barn stands a white farmhouse overhung by a tree in spring leafage. A woman is feeding chickens in the meadow that runs to the lower edge of the picture. A shallow pool is at the right behind which is a line of willow trees. The whole scene is bathed in the misty atmosphere of springtime. 


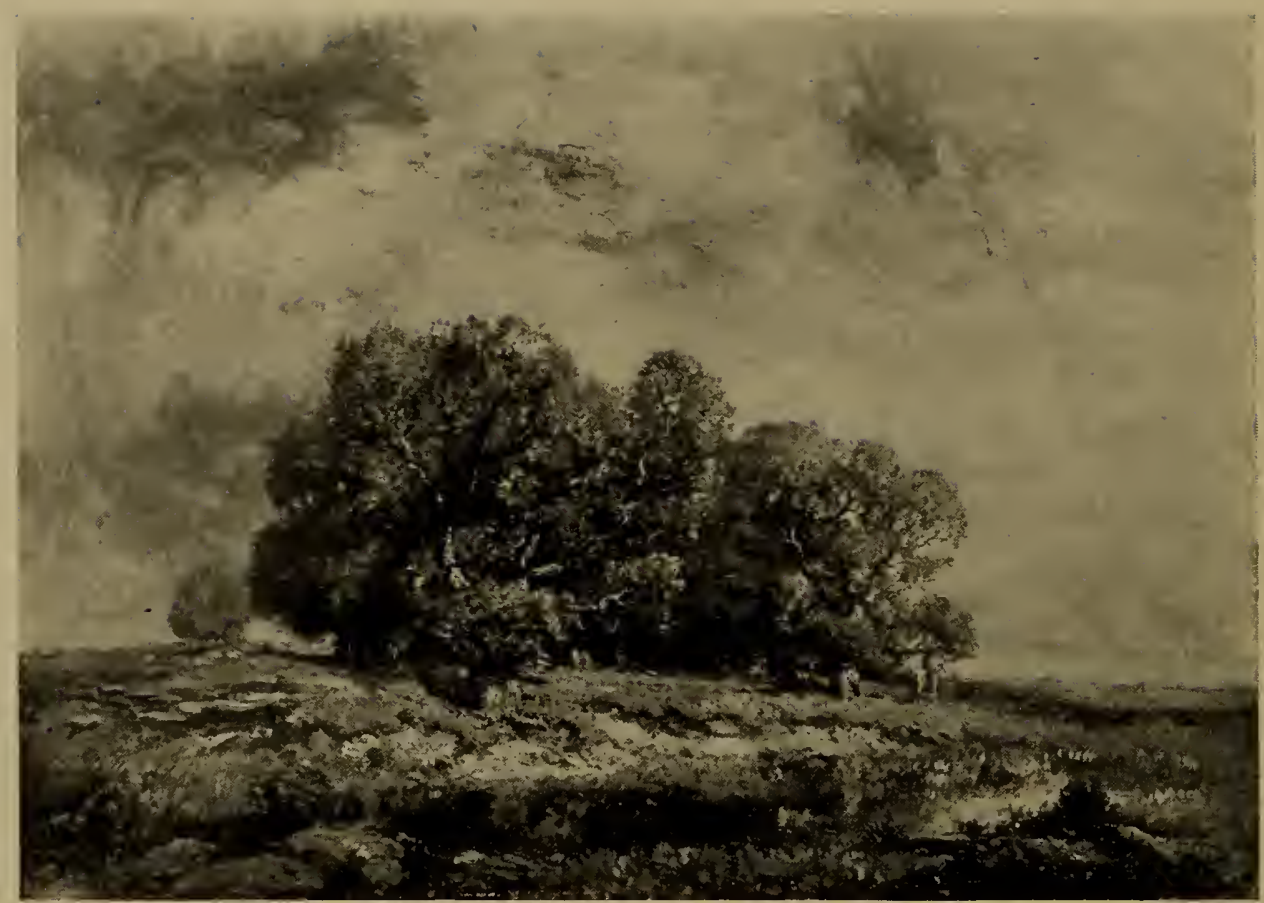

No. 51

HENRY WARD RANGER, N.A.

American : $1858-1916$

\section{A CLUMP OF OAK TREES}

Height, 18 inches; length, 26 inches

Ix the center of the picture on a slight elevation is a dense clump of old oak trees, their russet leaves touched to lighter hues by the strong light of the sinking sun. A red-shirted man on a white horse is at the edge of the trees. There is a pool in the foreground and beyoud, to right and left, stretches an empty landscape.

Signed at the lower left, and dated '96. 


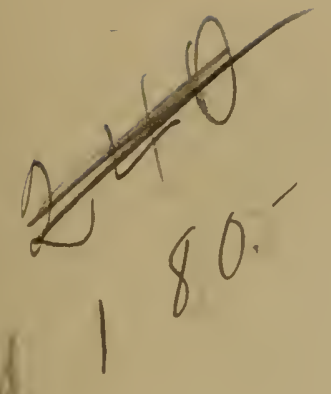

\section{No. 52 \\ HENRY WARD RANGER, N.A. \\ American : 1858-1916 \\ NEAR BOULOGNE}

Height, 18 inches; length, 26 inches

A FISHIN G smack is lying at anchor off the coast beneath a lovely blue sky barred with long lines of cumulus clouds through which patches of brighter blue sky are glimpsed, the whole making a canvas noteworthy for its calm serenity.

Signed at the lower left, and dated '93.

No. 53

HENRY WARD RANGER, N.A.

Americax : $1858-1916$

\section{WILLOWS AT BERTIER}

Height, 18 inches; length, 26 inches

A the right of the canvas the trees of the title form a dense mass along a grass road on which is seen a man riding a white horse. A solitary tree is between him and a pond in the foreground, while to the left stretches a broad expanse of meadowland with farm houses in a clump of trees. Overhead is an exquisite blue sky across which drive masses of fleecy clouds of gray and white. 
No. 54

HENRY WARD RANGER, N.A.

American : $1858-1916$

\section{SPRING LANDSCAPE}

Height, 18 inches; length, 26 inches

A GRAY-WALLEn farm outhouse with a steep roof stands in the shadow of a line of trees at the left of the composition. The sunlight casts deep shadows on the meadow in the foreground, where a pool reflects the blue of the bright sky overhead. Another line of trees stands by a wall crossing the center of the picture and beyond are groves of trees, their tops illumined by the strong sunlight.

Signed at the lower left and dated.

No. 55

\section{HENRY WARD RANGER, N.A.}

American : 1858-1916

\section{ROCKS AND DUNES}

Height, 25 inches; length, 30 inches

A rolling expanse of dunes back of the sea, a glimpse of which is caught over a depression of the land at the left. The earth is overgrown with coarse green grass and shrubs, and gray boulders and outcropping rock ledges are everywhere. A solitary tree rises from the top of the dunes against a windy sky. 


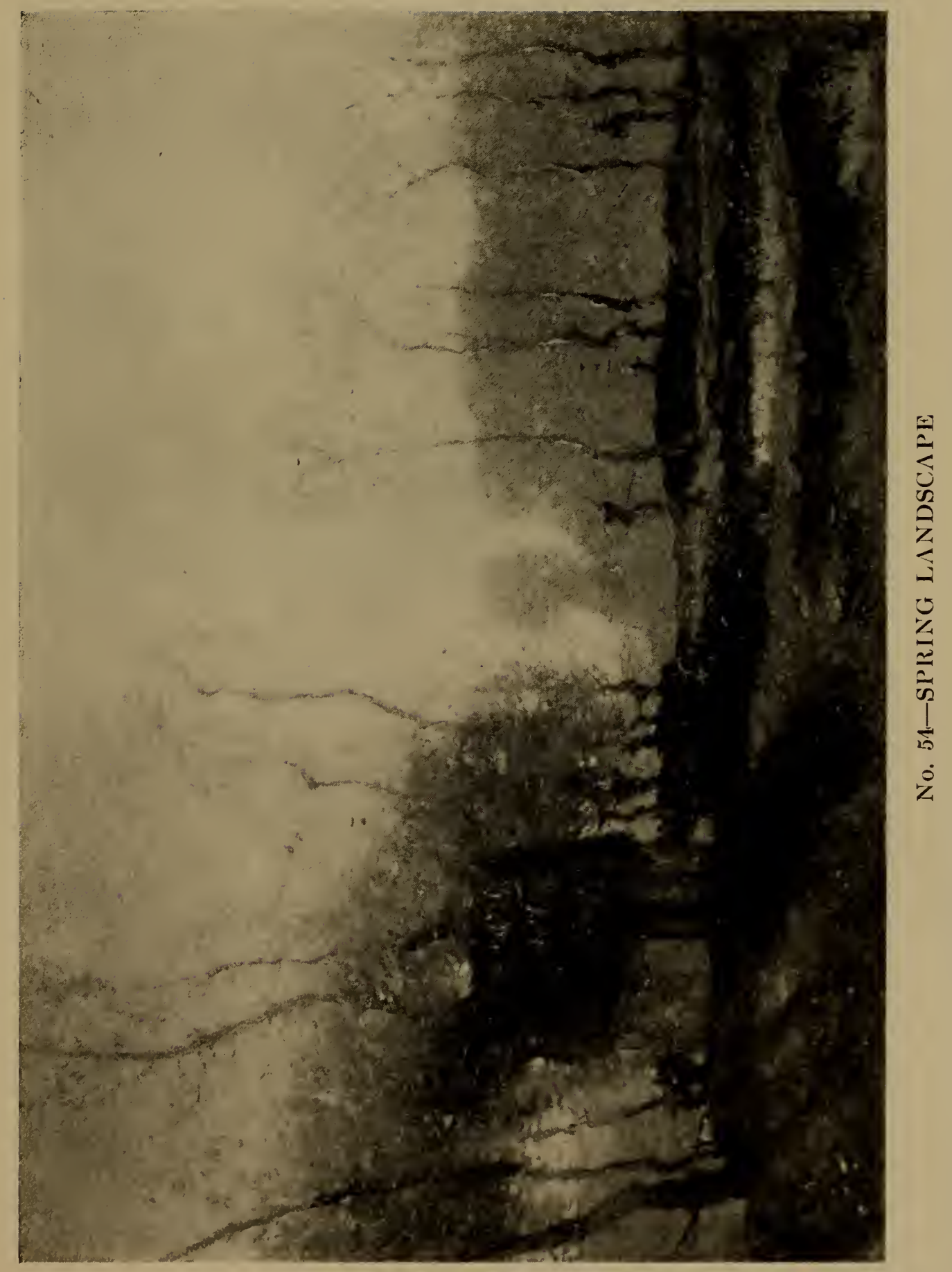




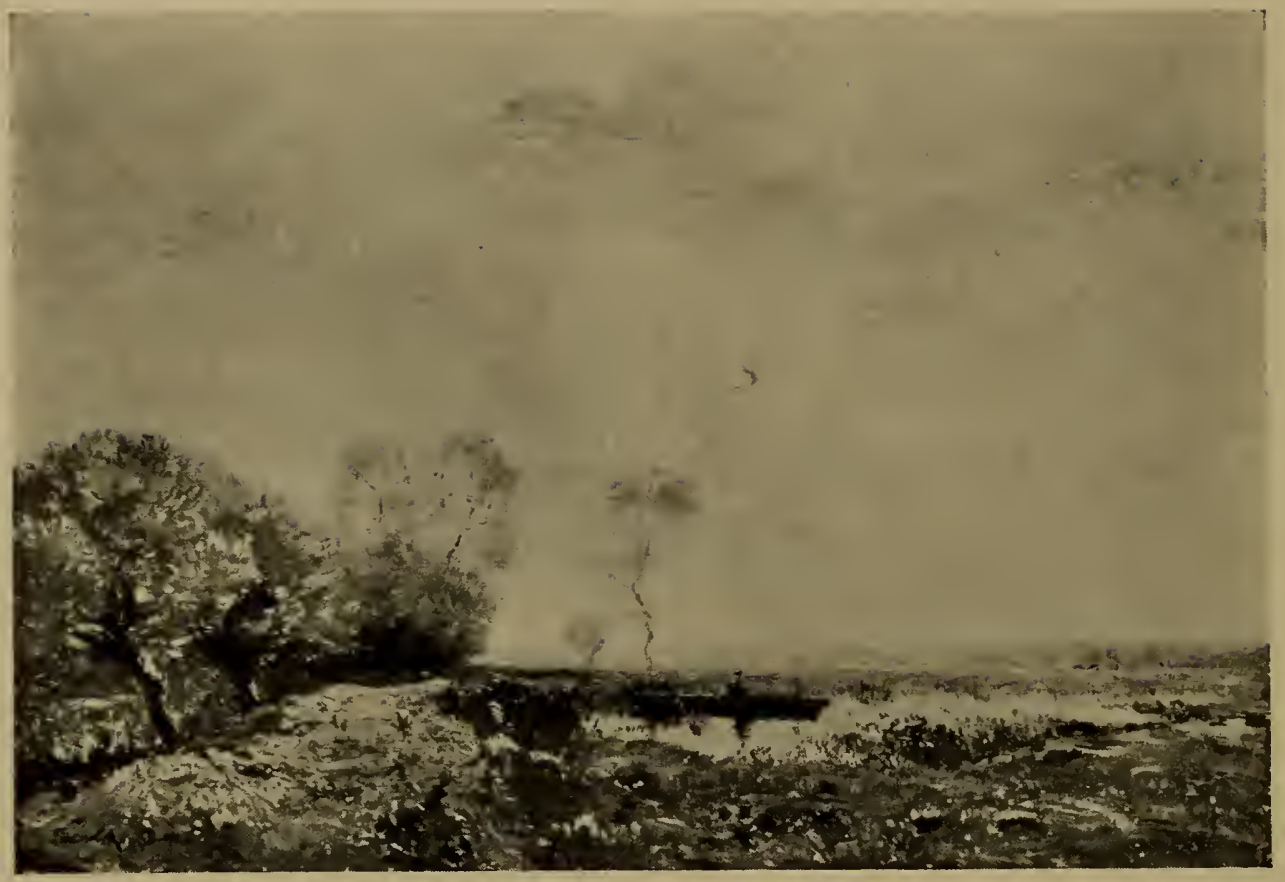

No. 56

\section{HENRY WARD RANGER, N.A.}

Americay : 1858-1916

\section{JUNE AT CHATEAUGAY}

Height, 18 inches; length, 26 inches

A BLUE sky overhead that changes to the palest tint on the horizon, across which float cumulus white clouds touched with mauve tones, overhangs a wide meadow through which runs a narrow stream. On the nearer shore is seen a man in a punt, while at the left is a thicket of trees. A village is indicated at the farther side of the meadow at the edge of the line of trees on the horizon. 
No. 57

\section{HENRY WARD RANGER, N.A.}

Anerican : 1858-1916

\section{THE MIRRORED OAK}

Height, 28 inches; length, 36 inches

In the center of the picture stands a noble oak tree, slightly apart from its fellows, its gray trunk and red-leafed branches reflected in the pool in the foreground. Figures are seen at the base of the tree on either side and beneath the oak one looks across a flat plain with a suggestion of a town and low hills on the horizon. The sky is greenish blue with yellowish clouds.

Signed at the lower left, and dated 1904.

No. 58

HENRY WARD RANGER, N.A.

American : 1858-1916

\section{MOONLIGHT-NOANK}

Height, 28 inches; length, 36 inches

A Longshore scene at Noank under the light of a hot summer's moon that shines full-orbed out of a greenish blue sky, its light tinting the few clouds to yellow and pale pink. Boats with riding lights lie at anchor and on the near shore are seen landings, a cottage and a clump of trees.

Signed at the lower left. 


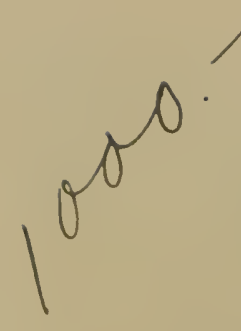

No. 59

HENRY WARD RANGER, N.A.

AIIERICAN : $1858-1916$

\section{THE SWAMP PASTURE}

Height, 28 inches; length, 36 inches

Throvgr two clumps of trees left standing by the woodchoppers, one of whom stands by a pile of cordwood in the center of the picture, the eye is carried across a wide expanse of flat country under a lovely blue sky crossed by yellowish white clouds. In the extreme distance are low hills that rise gradually at the left.

No. 60

\section{HENRY WARD RANGER, N.A.}

A MERICAN : $1858-1916$

\section{MARINE-GREEN AND GOLD}

Height, 28 inches; length, 36 inches

THE sinking sun is filling the brilliant sky with upshooting bands of yellow, red and darker toned clouds. Beneath this glory of light spreads a broad expanse of water on which float two boats that serve to accentuate the effect of solitude. The yellow and red tones of the sky are reflected in the greenish blue water. 


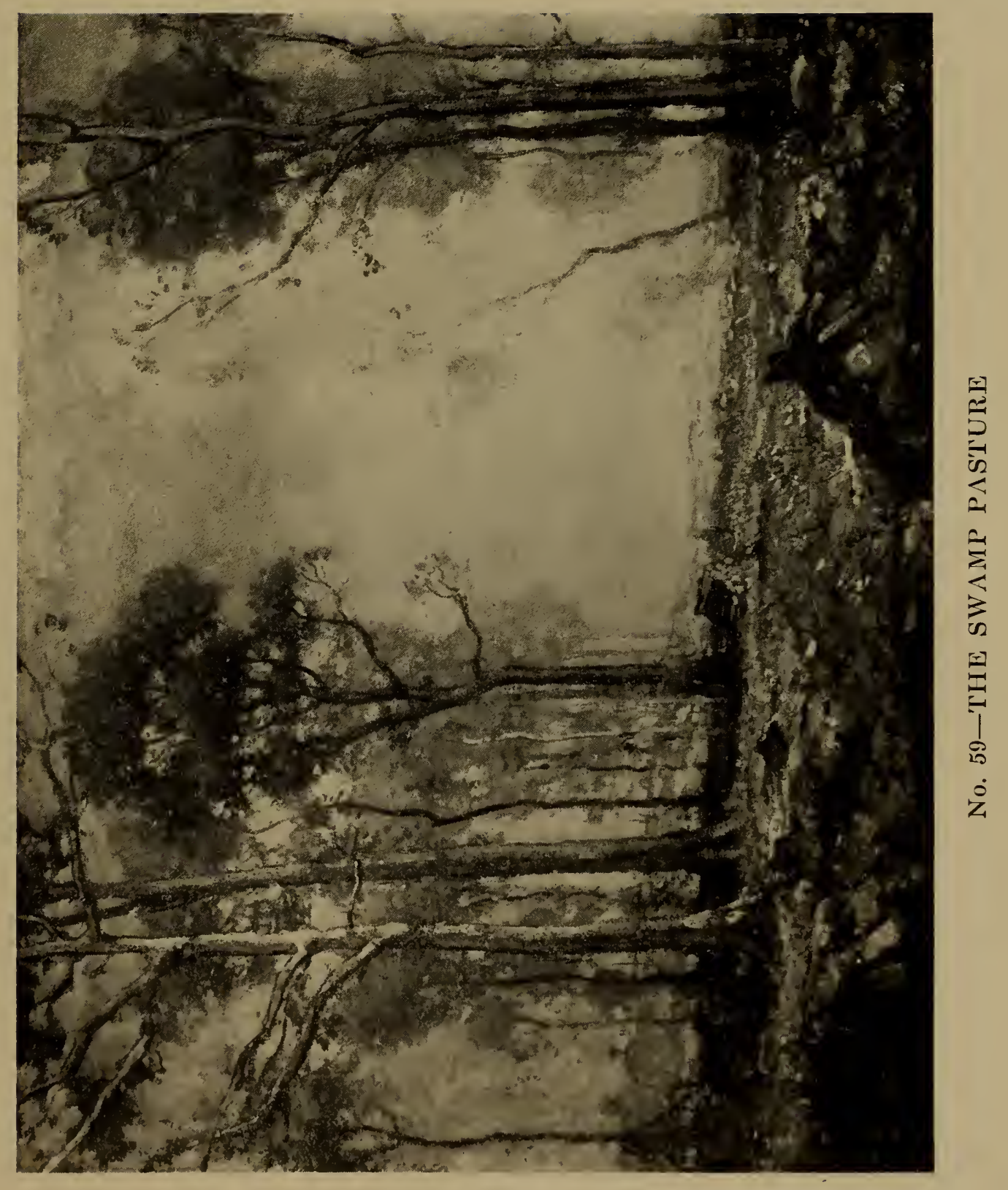


No. 61

\section{HENRY WARD RANGER, N.A. \\ AjIericaN : 1858-1916}

\section{SUNSET-RED AND GOLD}

Height, 28 inches; length, 36 inches

A REFULGENT golden sky touched with clouds tinted with red and pink lights is the center of interest in this canvas. Looking across from a pool in the foreground, where floats a red skiff with two figures seated in it, there is a grove of oaks at the right in full red and green foliage and at the left another distant grove in the hot sunlight, with a white church thrusting its spire up against the sky.

Signed at the lower left and dated.

No. 62

HENRY WARD RANGER, N.A.

AMERICAN : $1858-1916$

A CLEARING IN THE WOODS

Height, 28 inches; length, 36 inches

THE broad shadowed foreground slopes upward to a point and is lost to view where the clearing ends in the woods beyond. To the left the trees have turned a deep orange red and contrast strongly with those on the right with their dull-brown foliage. A couple of men in the opening are apparently gathering firewood, and a pile of fagots lie on the ground back of a large stone. A figure is seen approaching at the edge of the clearing in the background. The sky overhead is a greenishblue, and is streaked with clouds.

Signed at left, and dated 1899. 


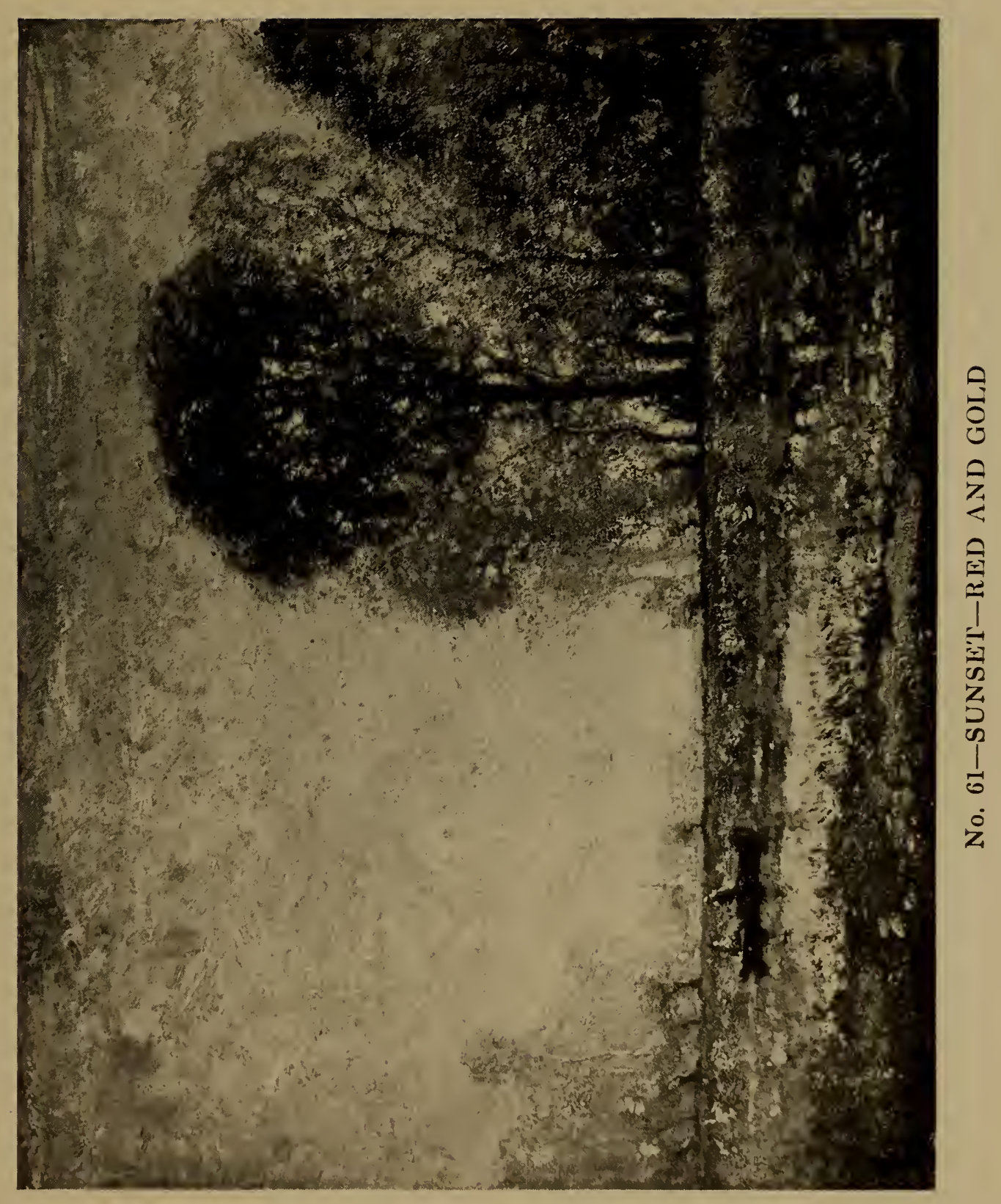


No. 63

\section{HENRY WARD RANGER, N.A.}

American : 1858-1916

\section{OLD NEW ENGLAND HOUSES}

Height, 28 inches; length, 36 inches

At the head of a salt water cove with old skiffs on its surface stand two New England houses at the end of a country road. Time has faded the paint on them into soft grays and pink and green, and this gayety of color is enriched by blooming trees nestling close to them. At the left a bare rocky hill rises. At the right, pasture land goes back to a line of sunlit trees. A white cloud floats in solitary glory above these trees and the uppermost sky is filled with white cloud forms. Figures are seen by the boats and on the meadows.

Signed at the lower left. 


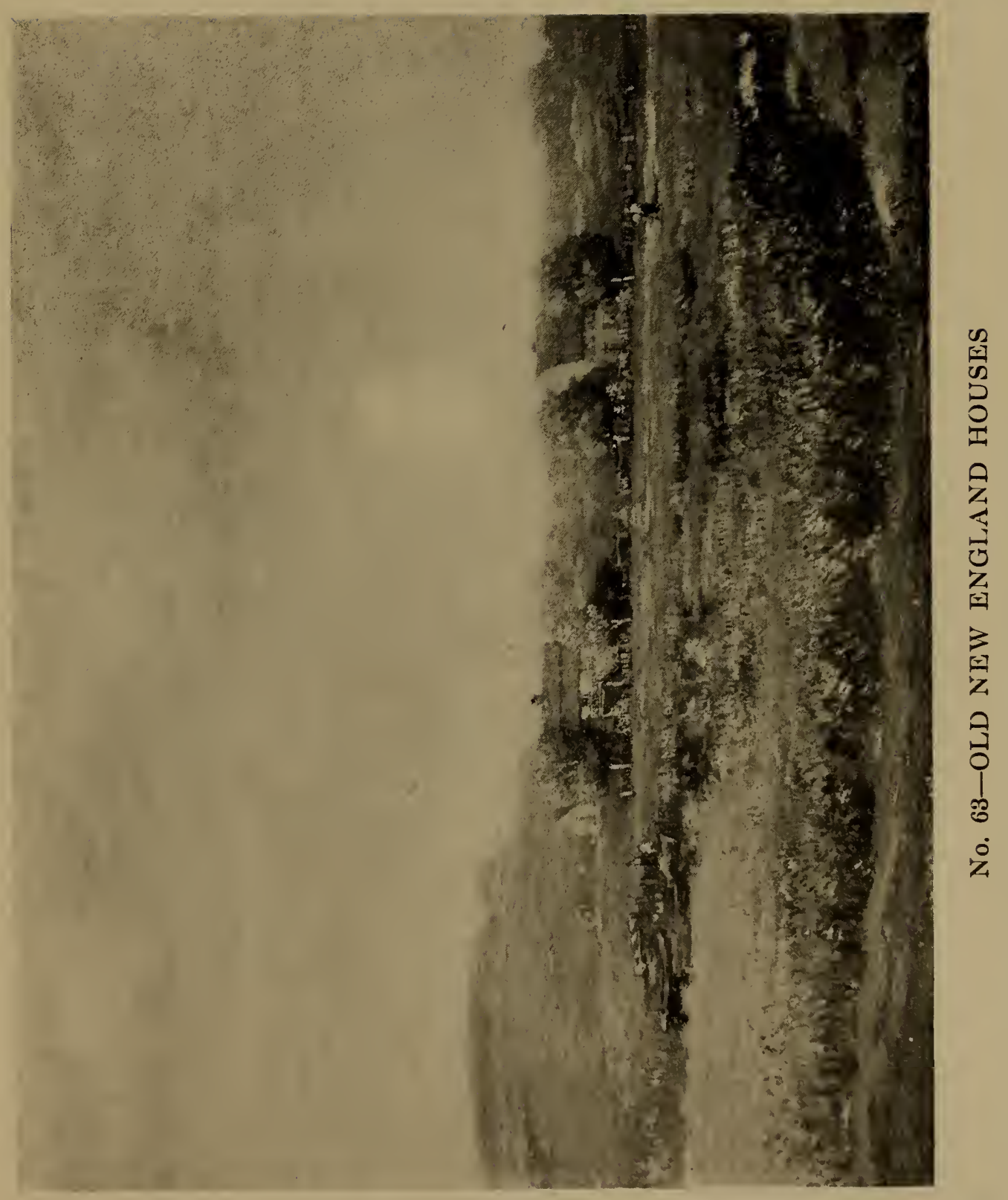


No. 64

HENRY WARD RANGER, N.A.

Anericay : $1855-1916$

THE PALISADES

Height, 28 inches; length, 36 inches

THE hot brilliance of the afternoon sun is the dominant note in this painting. It illumines the clouds barring the blue sky; it glows on the walls and towers of the buildings on the plain at the top of the Palisades, and is reflected in the blue and white water of the North River. Secondary to this play of gorgeous sunlight are the ships and factories and other waterside activities at the foot of the heights, these taking their proper place in the color scheme like a sonorous bass accompaniment to tonal flights in the treble.

Signed at lower left and dated.

No. 65

HENRY WARD RANGER, N.A.

AMericax : $1858-1916$

\title{
A LEDGE IN THE WOODS
}

\author{
Height, 28 inches; length, 36 inches
}

ON one of those still days in autumn when the sun burns with its heat, the artist has been looking through a grove of second growth trees at a ledge of lichen-covered rocks that rises abruptly from the level of the leaf-strewn earth in the foreground. Above the ledge on a natural terrace one looks through serried ranks of trees with one opening lit by the sun, while through the interstices of the trunks and foliage gleams a jewel-like blue sky. 
No. 66

\section{HENRY WARD RANGER, N.A.}

American : 1858-1916

\section{HILLTOP PASTURE}

Height, 28 inches; length, 36 inches

From a rock-strewn foreground the irregular tracings of an old cart road runs directly away from the spectator toward an opening in a low stone wall that cuts across the pasture. Beyond, a low hill rises to the skyline and in the center on its crest are seen a few cows grazing. The lichen-covered boulders and stone wall in the foreground make parti-colored notes in this tonal scheme of green and pale rose that is overhung by a bracing cloudland expanse, truly representative of the artist's nature.

Signed at the lower left and dated.

No. 67

HENRY WARD RANGER, N.A.

American : $1858-1916$

AUTUMNAL HUES

Height, 28 inches; length, 36 inches

Against a dense thicket of trees and underbrush at the left of the picture stands an old oak tree, its trunk and branches flushed with light from the westering sun, its foliage russet and yellow with the coming of the autumnal season. An old stone-and-rail wall circles from the extreme left across the composition enclosing a rough pasture, where two men stand before a brush fire. At the right a slope of rocky hillside is dappled with shadows from the slender birch trees dotted over its surface, and above all is a luminous sky.

Signed at the lower left, and dated 1899. 


\section{HENRY WARD RANGER, N.A.}

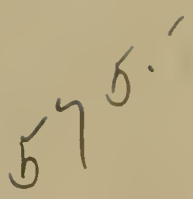

American : 1858-1916

\section{THE ARMORY}

Height, 28 inches; length, 36 inches

At the right of the canvas the western end of the Seventyfirst Regiment armory fills the immediate view. At the left is a row of old-fashioned brick stores and dwellings that carry the eye back to the tower of the old Grand Central Station. A shower is falling and the sidewalks and roadway are agleam with reflected lights, but toward the north the sky is clear and the sunlight glows on the station tower and the red fronts of houses on the east side of the avenue. A trolley car is emerging from the Park Avenue tunnel and a team of horses and truck are seen at the right.

Signed at the lozerer left.

Shown in the great Berlin Exhibition of 1903.

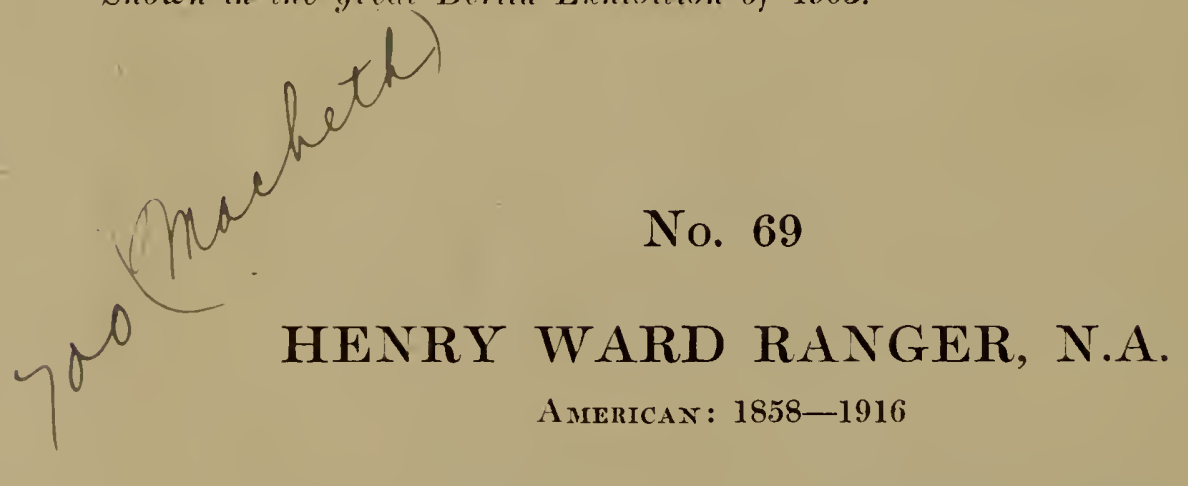

\section{BLUE SEA AND GOLDEN SKY}

Height, 28 inches; length, 36 inches

Across a flat expanse of blue water the sun is sinking in the west, filling the cloud-barred sky with the golden glory of its light. Two columns of smoke from unseen steamers rise up on the horizon into the windless air to the left and right, and at the left are seen two schooners drifting slowly along. The greenish water reflects the splendor of the sky in tones of gold and orange. 


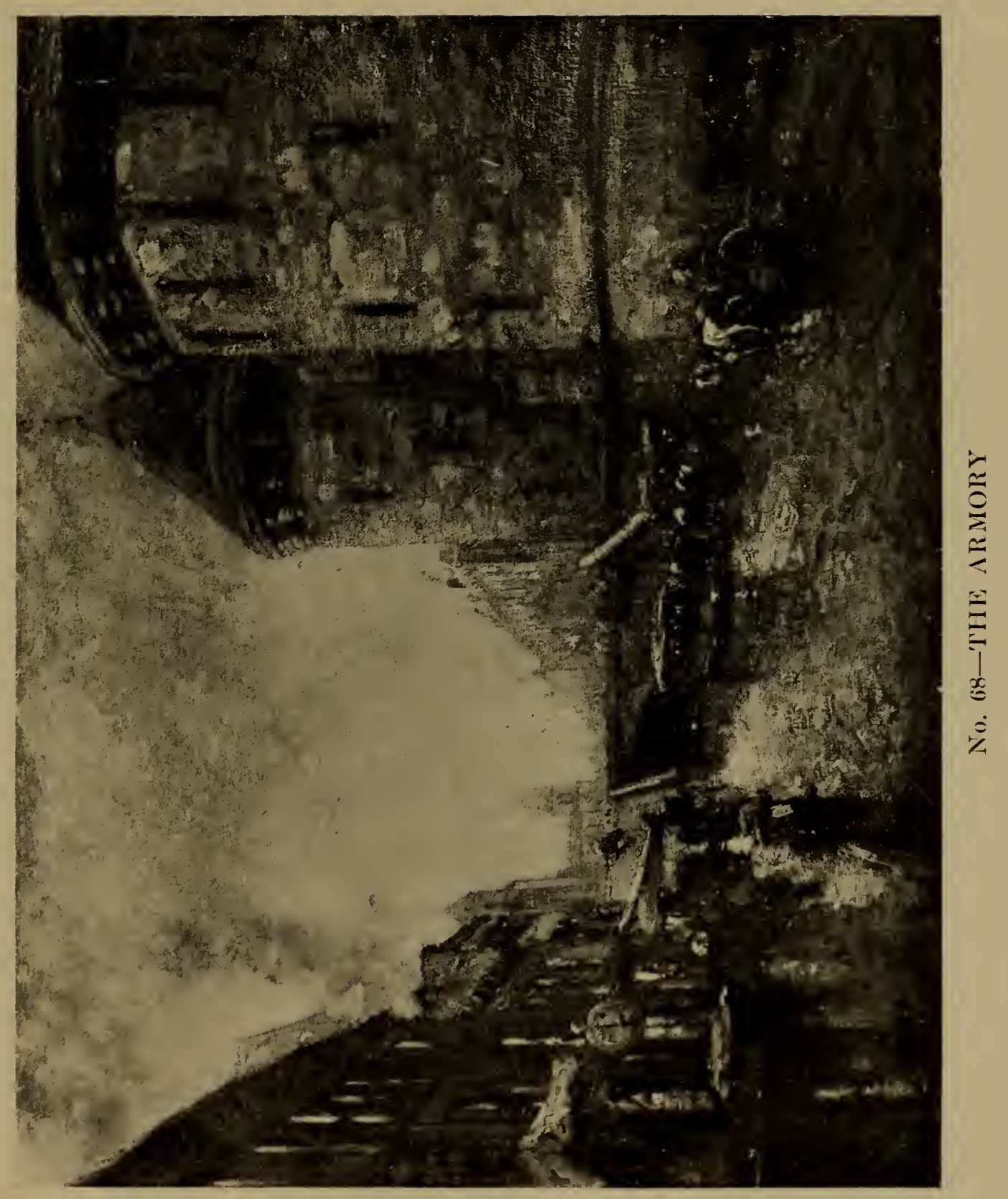


No. 70

\section{HENRY WARD RANGER, N.A. \\ Anerican : 1858-1916 \\ ROCKY LEDGE, CONNECTICUT}

Height, 28 inches; length, 36 inches

Out of a cleared field with stumps of trees and piled cordwood in the foreground, a ledge of rock rises into a low eminence. To the right the land slopes downward and in the strong sunlight are to be seen a group of farmers with horses at work. Two columns of smoke from burning brush rise into the air. A few spindling trees are still standing, making notes of green against a windy sky, the dominant tone of which is mauve. A flock of crows is seen flying upward at the left of the picture above the ledge of the title.

Signed at the lower left, and dated 1914.

No. 71

\section{HENRY WARD RANGER, N.A.}

American : $1858-1916$

\section{NOR'EAST WEATHER}

Height, 28 inches; length, 36 inches

A sINGLE skiff sails swiftly in a rising sea under a threatening sky. The rain beats mercilessly down, and the wind whips the restless waters into foam. The light blue sky is rapidly becoming darkened by storm clouds, and the scene fills one with apprehension for the tiny vessel in the approaching battie of the elements.

aracis $12 / 18 \# / 70$ 


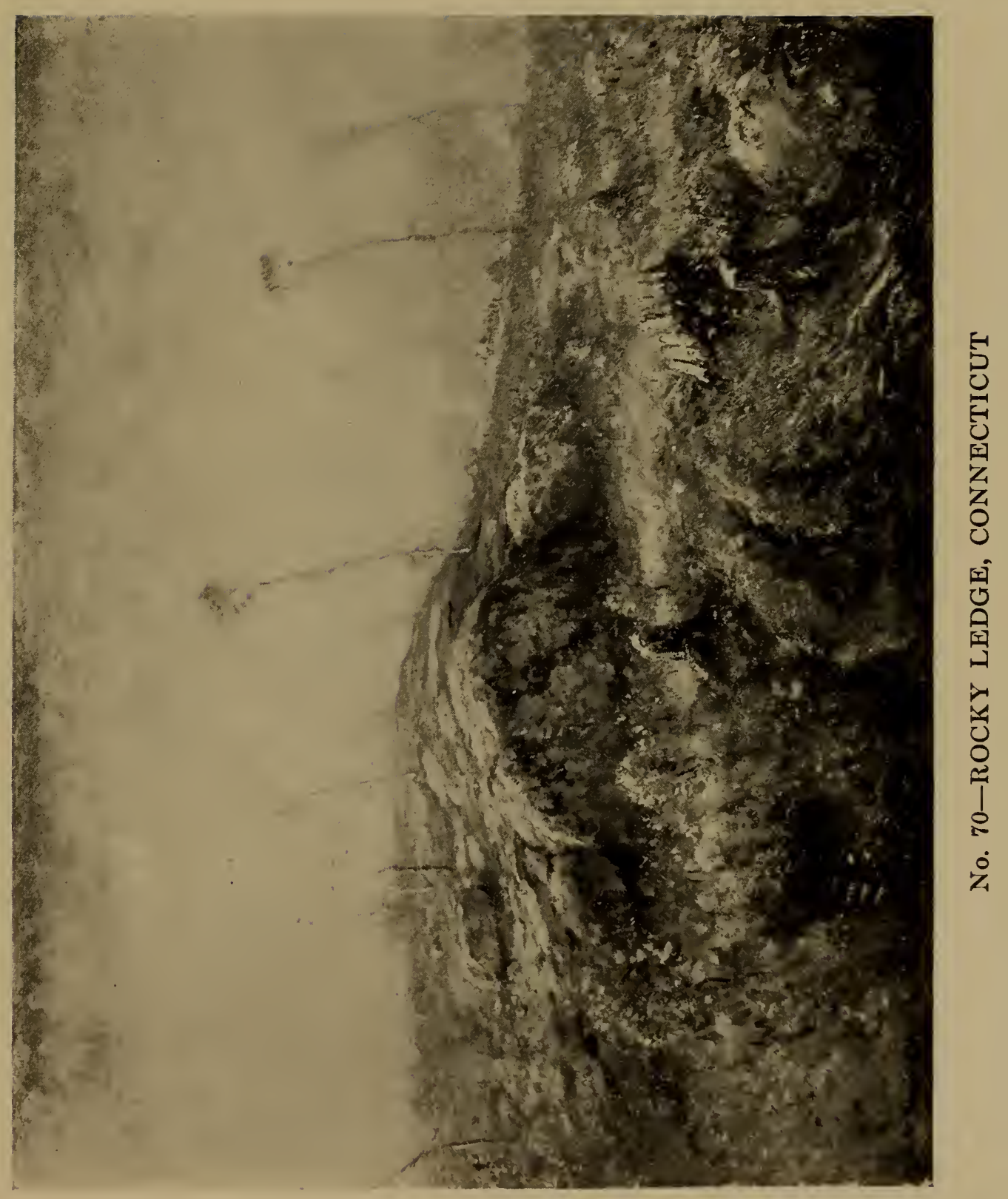


No. 72

\section{HENRY WARD RANGER, N.A. \\ American: 1858-1916 \\ STONY COVE AND HEADLAND}

Height, 28 inches; length, 36 inches

A Characteristic bit of one of Mr. Ranger's favorite painting grounds. The composition is dominated by a grass-grown rounded hill broken off into a sharp slope of bare earth on its seaward face to the left, giving a view of blue water and a distant line of hills beyond. In the foreground the waters of the Sound surge up into a boulder-strewn cove. A flock of birds fly above the broken crest of the hill and the whole scene is overhung by a pale blue sky crossed by white and yellow clouds. 


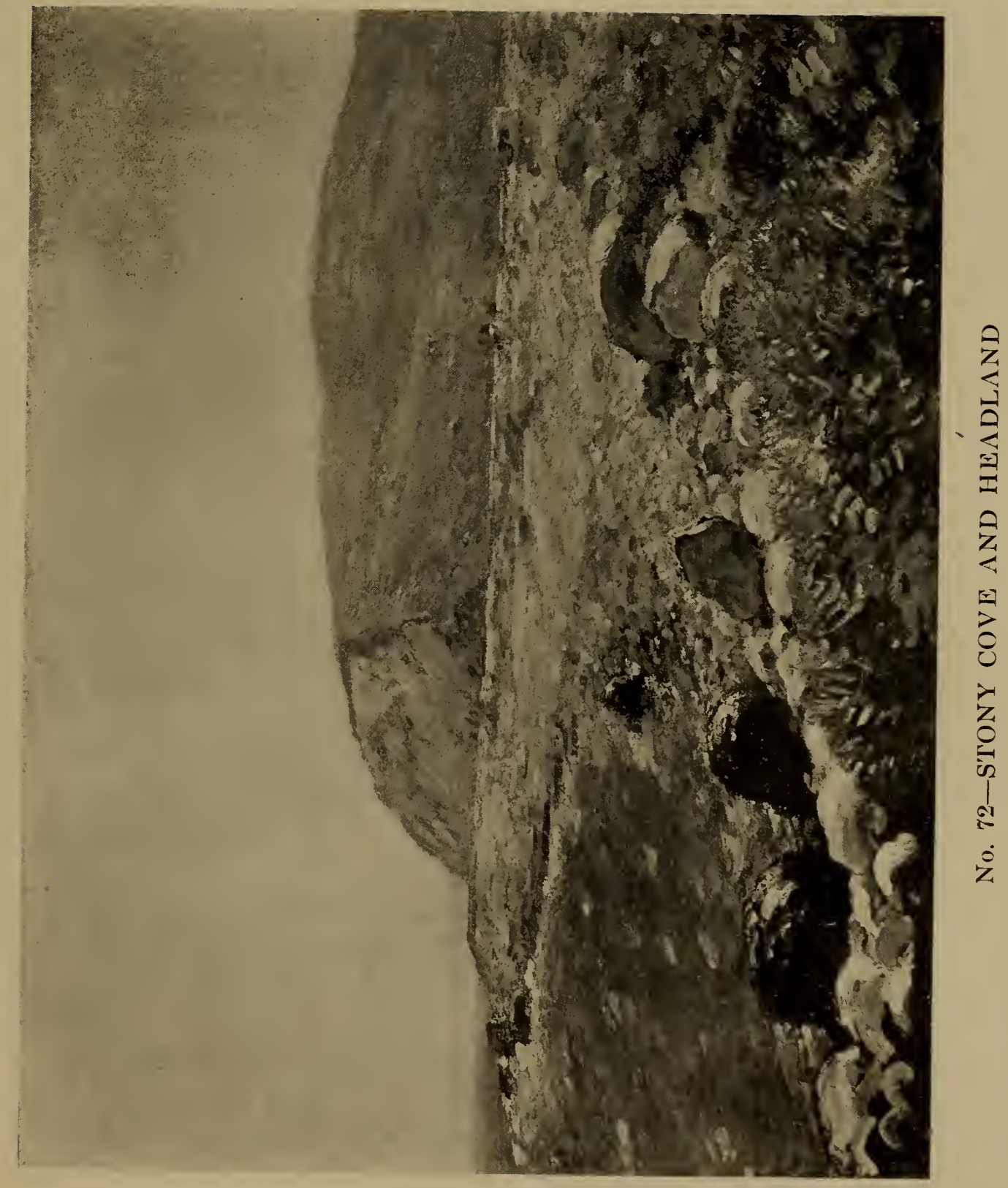


No. 73

HENRY WARD RANGER, N.A.

Americay : $1858-1916$

\section{TOP OF LORD'S HILL}

Height, 28 inches; length, 36 inches

A waGox path winds from the very rough and rocky foreground up the brow of the hill. Huge masses of rock lie to the left of the path, and the ground to the right is strewn with rocks and cords of wood. A wagon and some horses are seen at the end of the path, and alongside these a man is burning brush, the smoke scarcely rising in the still air. On the brow of the rock-bound hill a few trees are growing, scraggy and sparse of foliage from want of sustenance.

Signed at left, and dated 1910. 


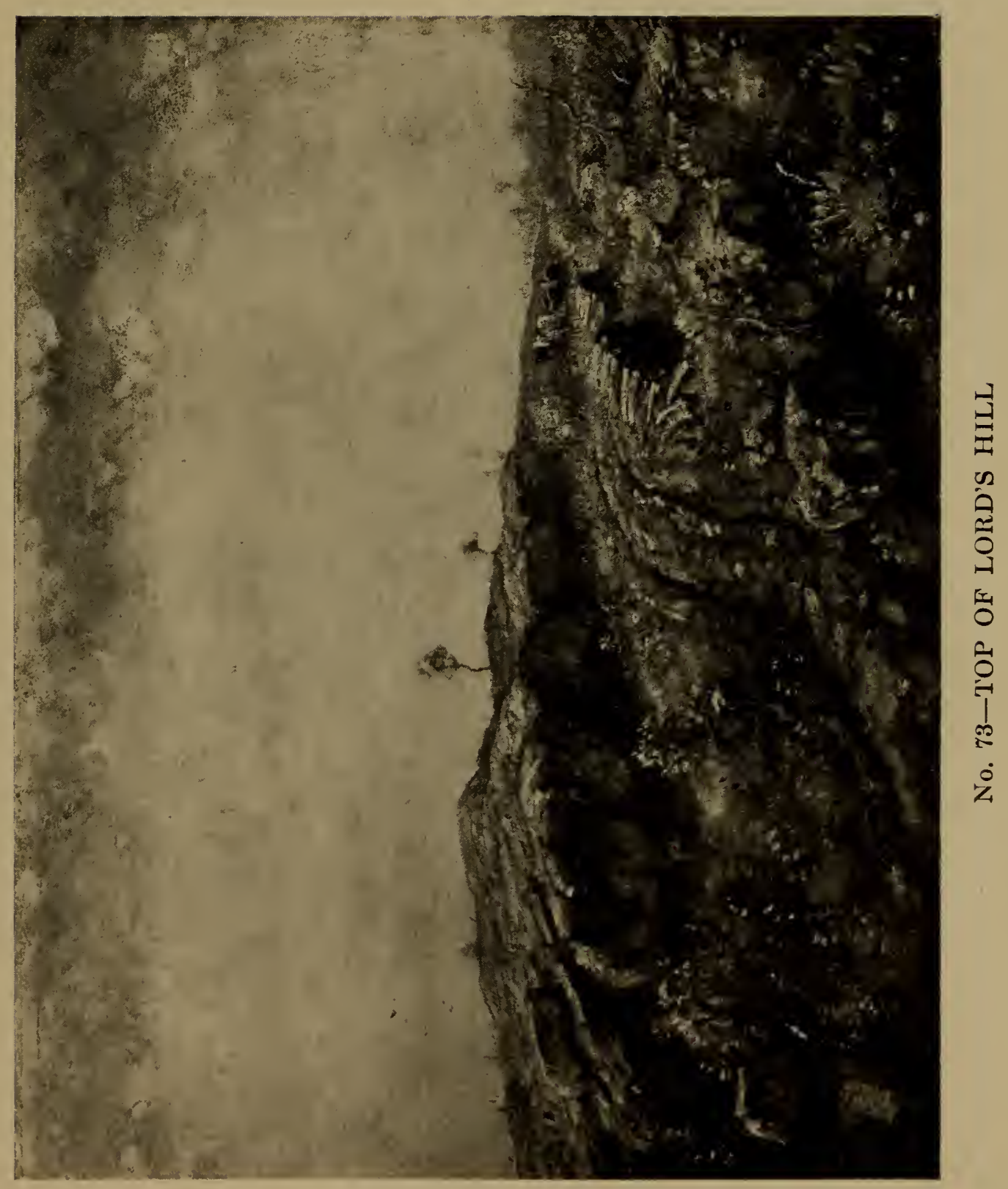


No. 74

\section{HENRY WARD RANGER, N.A. \\ AMERICAN : $1858-1916$}

\section{CLOUDLAND AND PASTURE}

Height, 28 inches; length, 36 inches

THis favorite theme of $\mathrm{Mr}$. Ranger shows once more the noble curves of "Becky Cole's Hill," its tawny green surface molded up against the cloudland of soft blue and yellowish whites. Sheep are seen grazing at the left of the hillside and on the right are clumps of trees thickening out into a dense grove. From the central foreground a cart track winds through a gap in the stone wall and in a circuitous trail up toward the crest of the hill. In contrast to the blue and white heavens the foreground presents tones of green, rose and tan.

Signed at the lower left, and dated 1901. 


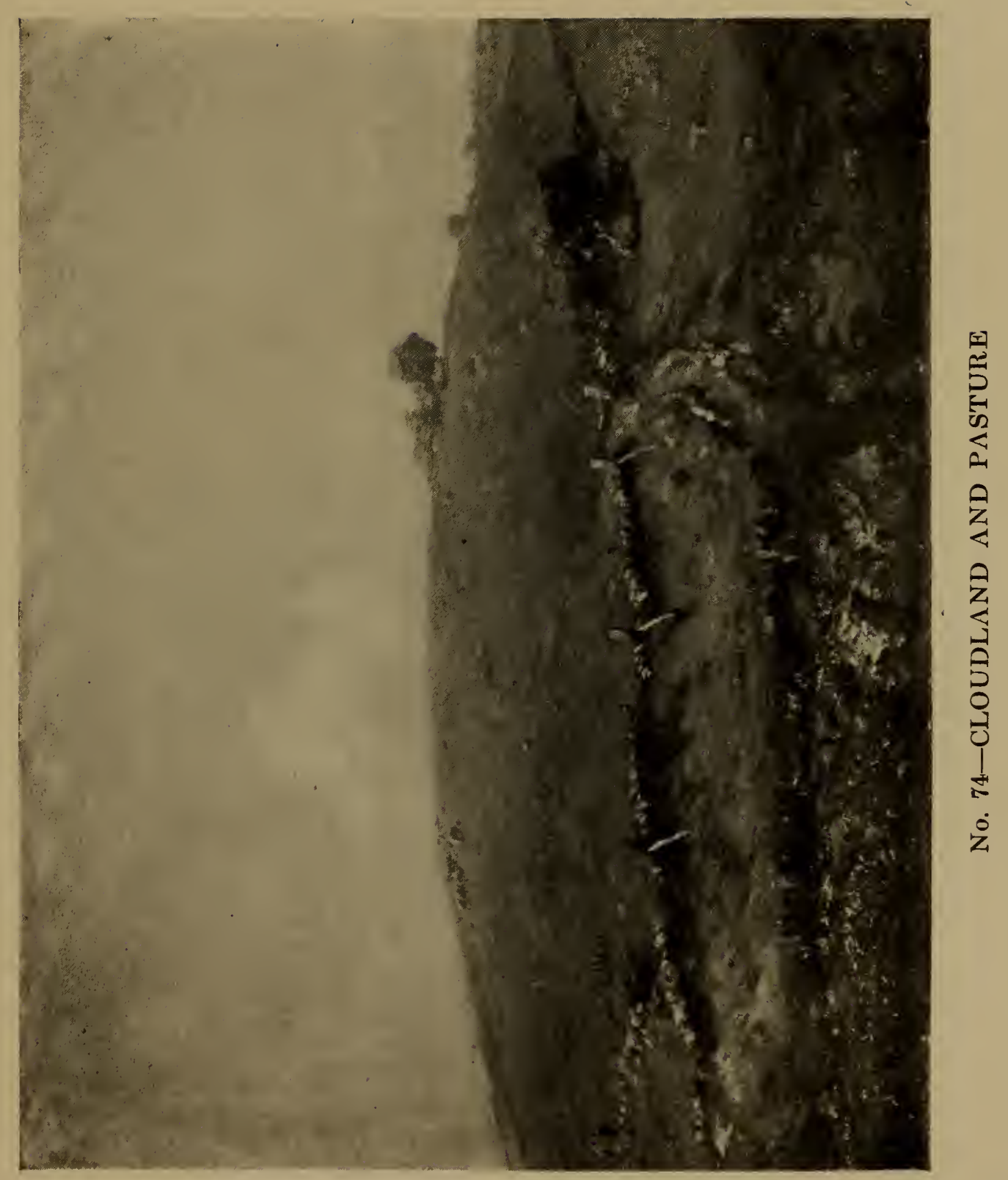


No. 75

\section{HENRY WARD RANGER, N.A. \\ Americas: $1858-1916$ \\ - $A U T U M N$}

Height, 28 inches; length, 36 inches

A LARGE tree stands at the foot of a knoll and dominates the foreground, which is in shadow, and broken here and there with rocks. A wagon path winds from the foreground to the right, and a stone fence crosses the hill in the middle distance, where two figures are seen walking over a rocky pasture. Beyond is a grove of trees almost bare of foliage and enveloped in a bluish atmosphere. Gray clouds cover the sky aloft, and patches of pale blue show in the rifts.

Signed at left.

No. 76

HENRY WARD RANGER, N.A.

Anerican : $1858-1916$

THE SENTINEL

Height, 28 inches; length, 36 inches

A MightY oak, aged and gnarled, stands impressive in its solitariness and grandeur in an open, ploughed up field. The russet tones of autumn over foliage and landscape give the picture a rich Rousseau-like quality. To the left is a waste of scrub, and at the right are two smaller oaks, lesser guardians of the woods behind them. The sky is crowded with huge banks of clouds surcharged with rain and in fitting harmony with the almost desolate landscape below. In contrast to this feeling of solitude are the two patches of blue sky, deeper overhead and lighter at the horizon. 


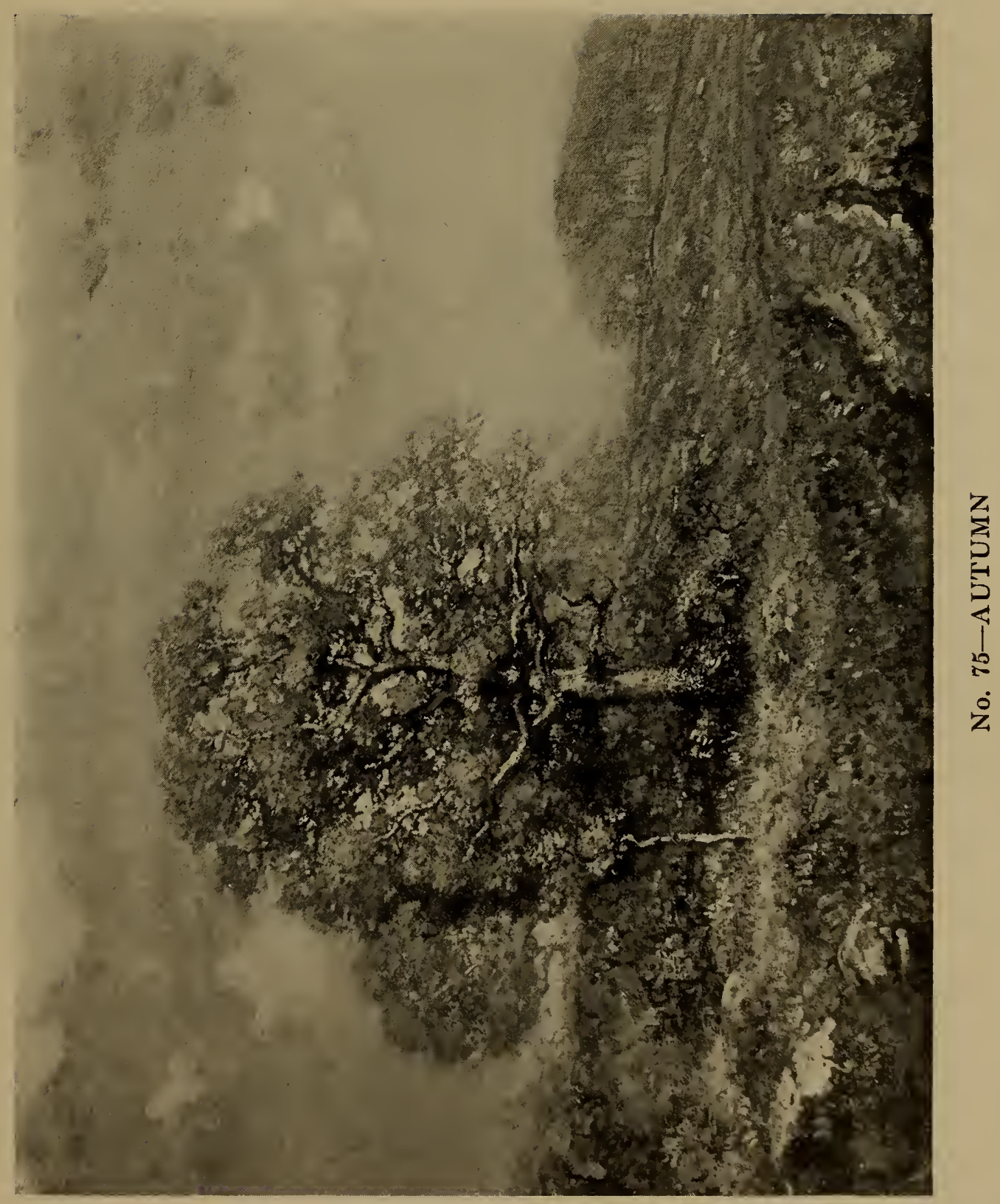


No. 77

\section{HENRY WARD RANGER, N.A. \\ American : 1858-1916}

\section{A VIEW OF THE SOUND}

Height, 28 inches; length, $\mathbf{3 6}$ inches

A GREAT oak, sparsely foliated, stands at the left of the foreground, which is in deep shadow. Back of this a mass of trees of more slender growth and covered with foliage tinged lightly with autumn colors grow down to the water's edge. Between these trees and those at the right of the canvas the scene opens on a clear view of the Sound straight across to the opposite shore. The water near the shore takes on the blue colors of the sky overhead, and toward the farther shore reflects the brightness of the sun-touched clouds. Two men have drawn their red boat on shore and are resting in the shadow of the trees.

Signed at left, and dated 1906.

No. 78

HENRY WARD RANGER, N.A.

Americay : $1858-1916$

AN ARABESQUE

Height, 28 inches; length, 36 inches

Looking into the woods the eye rests on a huge oak which stands a short distance from the foreground. Two heavy limbs grow from the left base of the tree and reach outward and upward to the top of the canvas. The foreground is thickly carpeted with dried autumn leaves, reflecting here and there patches of bright sunlight filtering through the foliage above. The ground rises slightly back of the oak and is covered with a dense growth of trees clothed in the rich tones of the late autumn. In the clearing at the right men are burning leaves, as indicated by the faint blue smoke that rises. Patches of sky show faintly through the leaves.

Signed at left. 


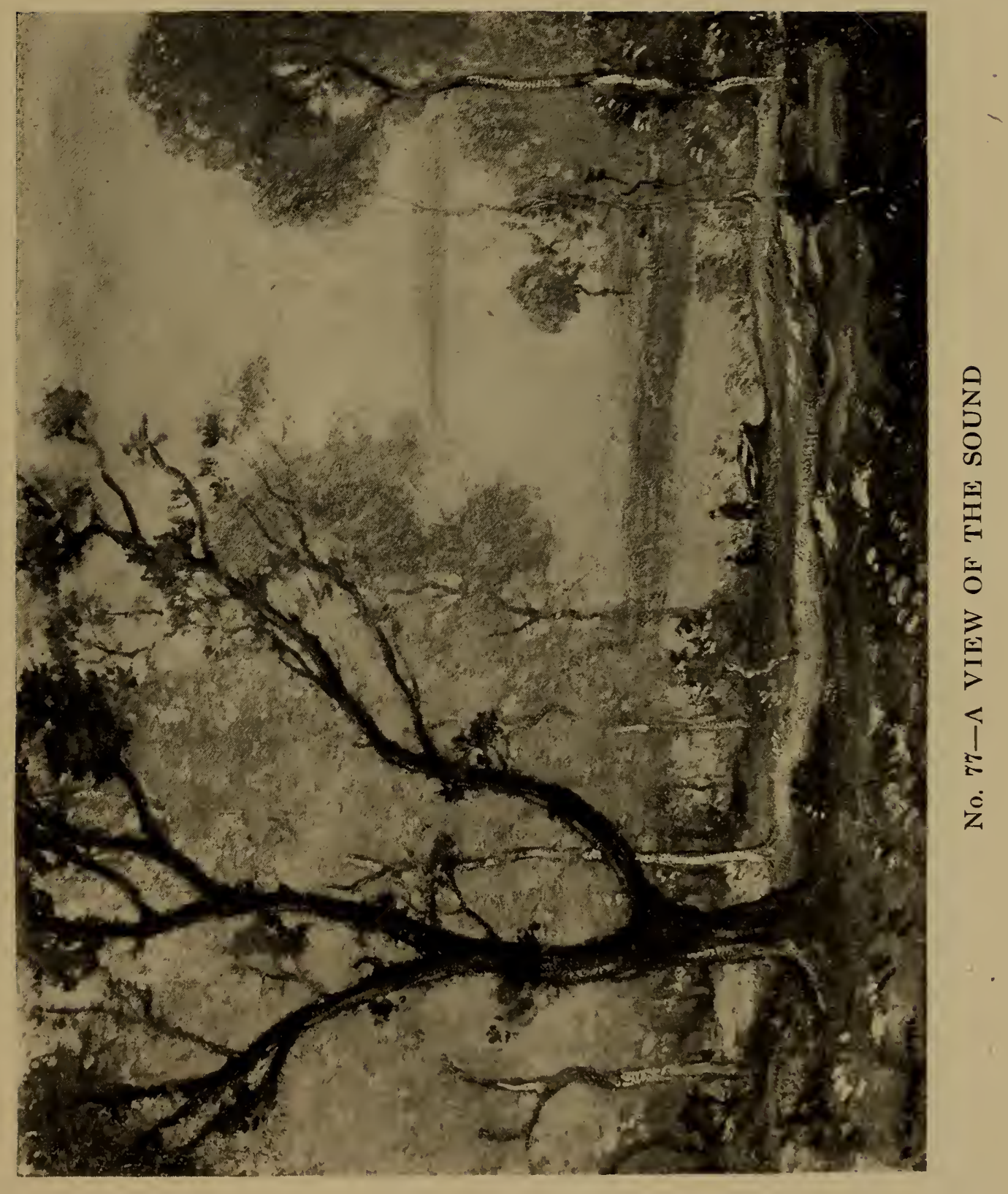


No. 79

\title{
HENRY WARD RANGER, N.A.
}

American : 1858-1916

\section{THE OUTSKIRTS OF THE WOODS}

\author{
Height, 28 inches; length, 36 inches
}

A DEEP and much furrowed wagon road leads from the foreground between rows of stately, slender trees of gray-green foliage and disappears in the distance. A clearing has been made on either side of this rough road and the cordwood is piled by the way. Masses of clouds, dull and heavy overhead, lighter and indefinite as they extend horizonward, move lazily across the great expanse of sky, blue patches of which show intermittently through the breaks. 


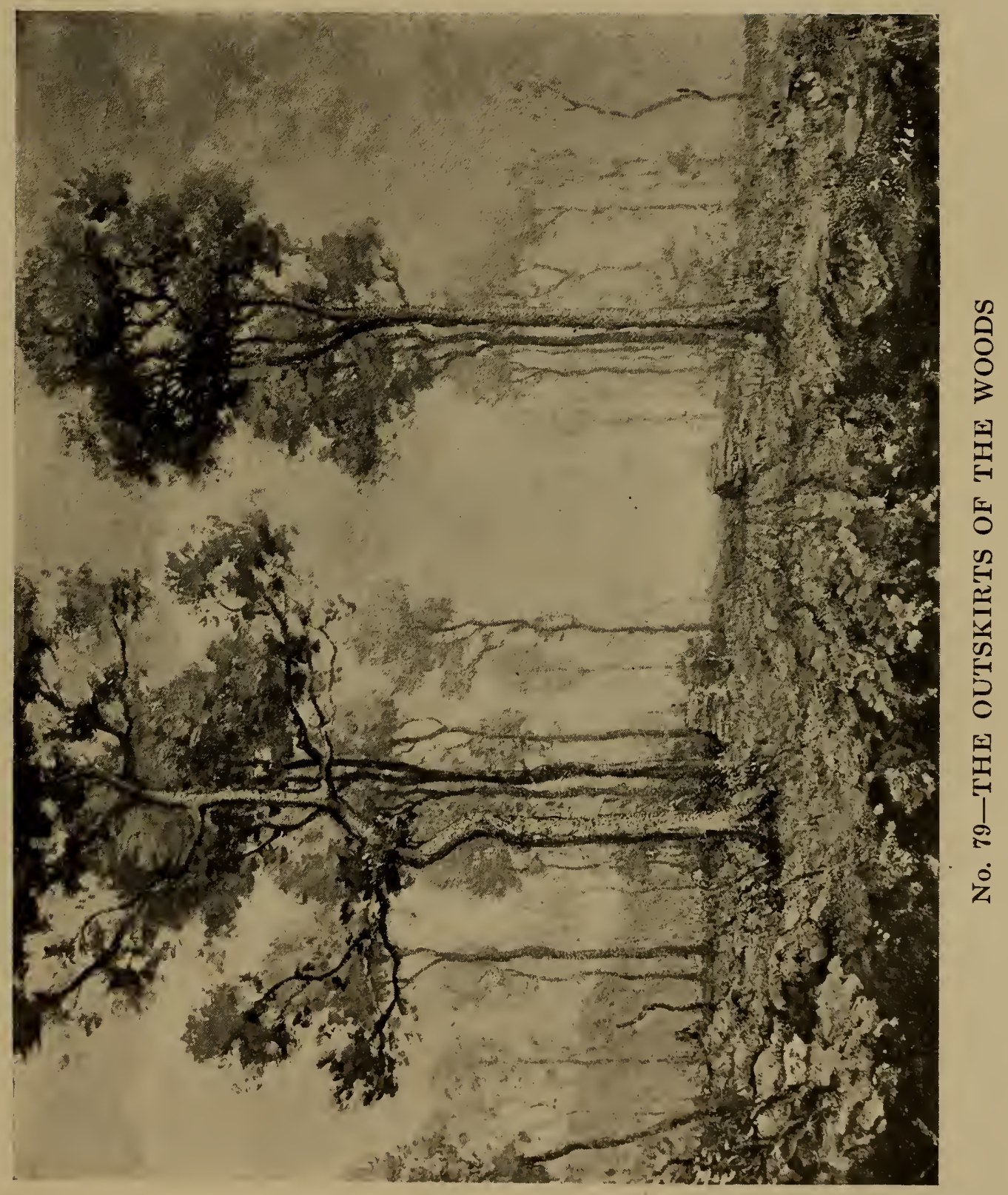


No. 80

\title{
HENRY WARD RANGER, N.A.
}

\author{
A Mericax : 1558-1916
}

\section{NEW YORK FROM}

\section{WEEHAWKEN HEIGHTS}

\author{
Height, 28 inches; length, 36 inches
}

Aloxg the rain-soaked road which leads from the river to the immediate foreground several wagons and a number of laborers approach toward the spectator. At the right rises a high embankment, and at the left a train yard is enveloped in the steam from the locomotives. The Hudson, reflecting the strong golden sunlight, presents a busy scene with tug boats and ships of various types plying up and down its surface. The uneven sky line of Manhattan is seen across the water, and on the horizon at the right masses of bluish white smoke emerge from steamers going seaward. 


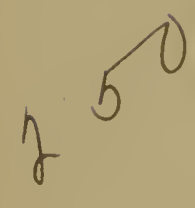

\section{No. 81 \\ HENRY WARD RANGER, N.A. \\ American : $1858-1916$}

\section{ALONG THE DOCKS}

Height, 28 inches; length, 36 inches

A ReCTANGular pile of dull red buildings rises from a river's bank at the left of the picture; ocean-going ships and "windjammers" are seen moored at the piers below the great structure. In contrast to this low-toned mass of color, the river, the low hills on the other side of the stream, and the cloud-obscured sky are all in a scheme of pale greens, whites and blues, the surface of the stream being broken with curling whitecaps from the keen wind that blows smoke and steam about in lively commotion.

Signed at the lower left, and dated 1892. 
No. 82

\section{HENRY WARD RANGER, N.A. \\ A viericax : $1858-1916$ \\ A NOANK PASTURE}

Height, 28 inches; length, 36 inches

Ax old wagon path winds up a rugged hill to the right through an opening in an old stone fence and ends in a field where some cows are grazing. In the foreground a tiny brook reflects the blue of the sky, and to the left, broken frequently with rocks and stones, a green pasture stretches to the middle distance, beyond which, enveloped in a haze, a distant settlement is seen. The greenish-blue sky is filled with clouds touched with the golden light of the sun.

sold i Wh Witchus ung duand signed at left, and dated 1915.

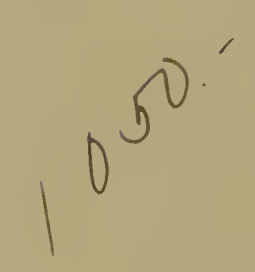

No. 83

\section{HENRY WARD RANGER, N.A. \\ AMERICAN : $1858-1916$}

\section{AUTUMN, MASON'S ISLAND}

Height, 28 inches; length, 36 inches

Ax old and sturdy oak spreads its branches almost across the face of the canvas, protecting, as it were, the trees of more slender growth around it. The foreground is in deep shadow and contrasts strongly with the middle distance, which is bathed in bright sunlight. An old fence reaches across the canvas, and beyond this two men are burning brush, the blue smoke rising through the trees at the right. In the background the foliage of the dense woods has taken on the warm tones of Autumn. 


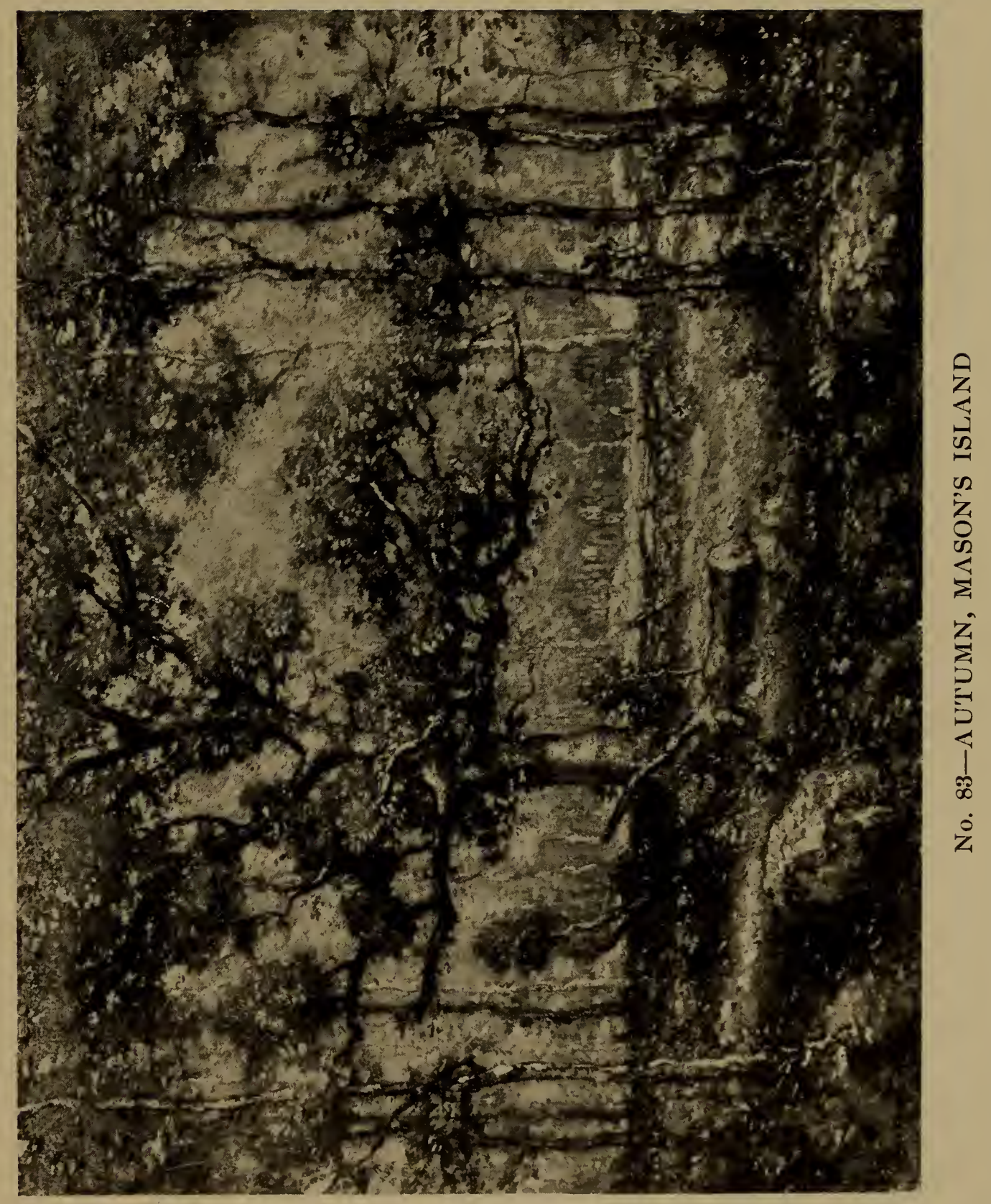


\# 52 and t 55

Resold gnd Enering 


\section{SECOND AND LAST EVENING'S SALE}

FRIDAY, MARCH 30, 1917

AT THE AMERICAN ART GALLERIES

BEGINNING AT 8.15 O'CLOCK

\section{WORKS BY CONTEMPORARY ARTISTS \\ COLLECTED BY THE LATE \\ HENRY WARD RANGER, N.A.}

Catalogue Nos. 84 to 99 , inclusive

No. 84

J. FRANCIS MURPHY, N.A.

American : 1853

LANDSCAPE

Height, 8 inches; length, 12 inches

Beneath a blue sky crowned by rolling white clouds touched to pale tints of red by the glow of the sun lies a broad landscape in green and red tones. A grove of trees is at the right in deep shadow and at the left a distant forest is indicated. 
No. 85

\section{GEORGE POGGENBEEK}

Dетсн: 1821-1903

\section{LANDSCAPE AND CATTLE}

Water Color: Height, 12 inches; width, 8 inches

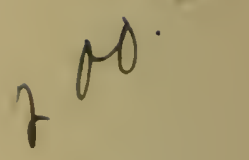

Two cows, one black and white, the other brown, are approaching a pool of water in the immediate foreground. An old wooden fence stands at the right, and back of this some slender trees are growing. The sky is a sombre gray and the chill atmosphere is filled with dampness.

Signed at left, and dated 'si

No. 86

JOHANNES HENDRIK WEISSENBRUCH

Dчтсн : $1824-1903$

\section{HOLLAND LANDSCAPE}

Water Color: Height, 13 inches; width, 9 inches

SEVERAL old houses stand at the left overlooking the water in the foreground. Near one of these houses a woman is spreading clothes to dry on the bank of the canal. Thesky is filled with heary gray clouds and shows patches of blue near the horizon. 
No. 90

\section{WILLIAM GEDNEY BUNCE, N.A. \\ A Merican : $1840-1916$ \\ VENETIAN MORNING}

Panel: Height, 14 inches; length, 17 inches

ON a sea broken with wavelets a group of feluccas with stained sails float in picturesque confusion at the right. At the left other similar craft are seen in the distance and a windless blue and gray sky rises to the top of the picture.

Signed at the lower left, W. Gedney Bunce, Venice.

No. 91

JOHN CONSTABLE, R.A.

ENGLISH : $1776-1837$

\section{THE PASSING STORMi}

Panel: Height, 14 inches; length, 21 inches.

Over a steep hillside, crowned by an old windmill, the sun is bursting through the storm clouds that are driving away to the left of the picture. A red-shirted drover is plodding along the face of the hill behind his cattle and at the base is a thicket of bushes, a rail fence, and a mounted horseman. At the left a red-roofed farmhouse and a white church spire make accents of color against the black cloud. 
No. 92

\section{JOHN HENRY TWACHTMAN}

American : 1853-1902

\section{THE RIVER'S EDGE}

Height, 16 inches; length, 20 inches

- One of Twachtman's canvases in his earlier manner broadly brushed in. At the right a grass-grown bank rises from the river's edge, with trees grouped in the center of the composition. A boat landing, with ladders at either end, extends out into the stream, behind which is a line of trees. A lovely cloudflecked sky rises to the top of the canvas.

Signed at the lower right, J. H. Twachtman, '79.

No. 93

\section{JACOB SIMON HENDRIK KEVER}

DUTCH : $1854-$

\section{THE SPINNING WHEEL}

Water Color: Height, 15 inches; length, 16 inches

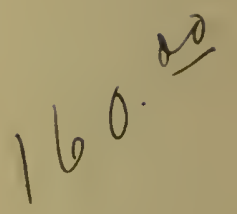


No. 101

\section{HENRY WARD RANGER, N.A.}

Americax : 1858-1916

\section{SAN JUAN, PORTO RICO \\ Panel: Height, 16 inches: rcidth, 12 inches}

Frour a grassy meadow in the foreground where two men are seated in an old boat the spectator looks across an inlet of the sea to the picturesque city of San Juan. Ships and houses make contrasting notes of color against the deep blue sky that is filled overhead with great masses of gray and white clouds, the rain bearers of this tropical island.

Signed at the lower left.

No. 102

HENRY WARD RANGER, N.A.

AMericax: 1855-1916

\section{SEA AND SHORE}

Panel: Height, 12 inches: length, 16 inches

A BIT of rock-strewn beach is in the foreground, from which one looks across an expanse of blue water dotted with whitecaps. A lighthouse on a point of land and a stone beacon add human accents to the scene. 


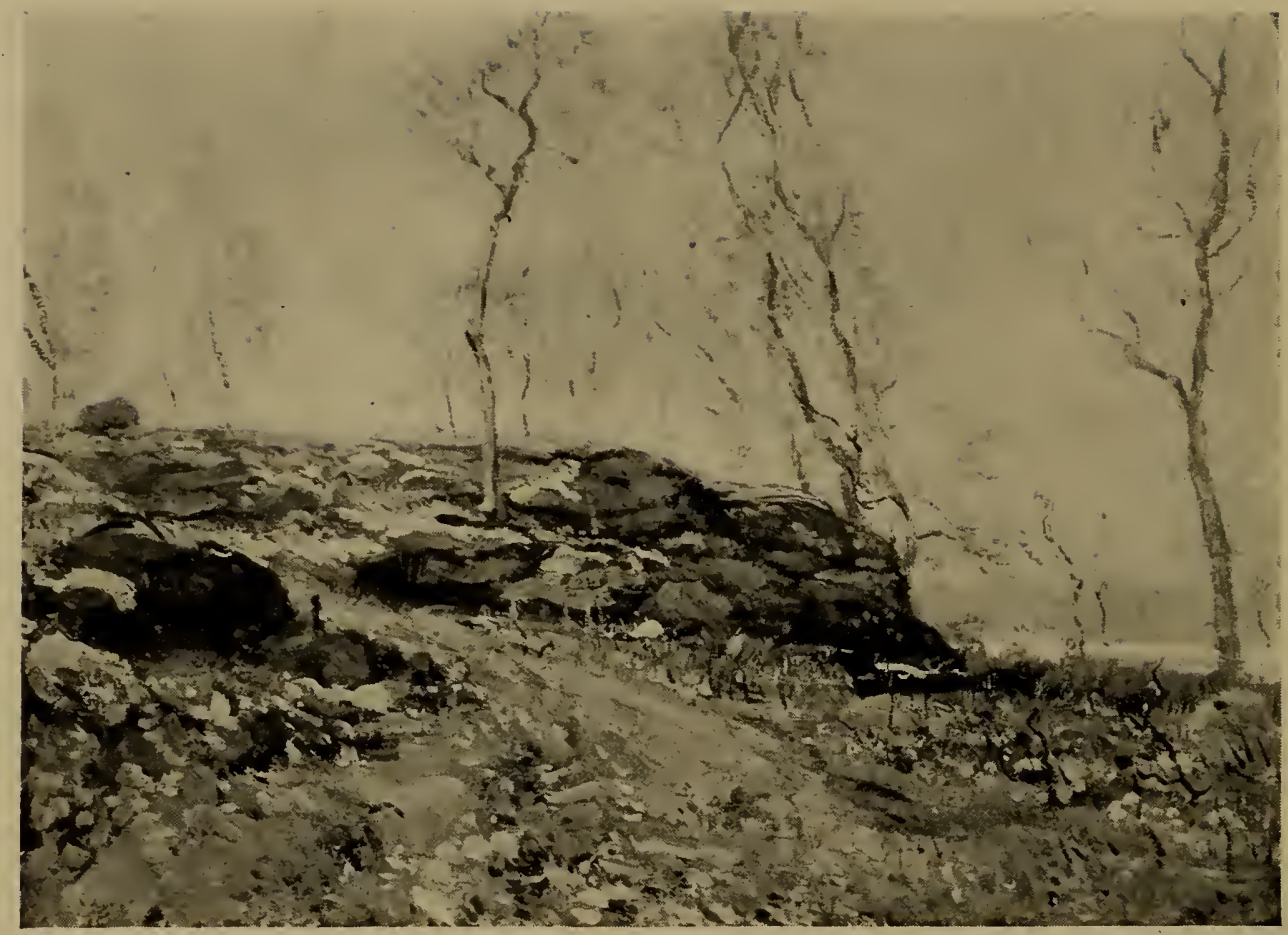

No. 103

HENRY WARD RANGER, N.A.

American : $1858-1916$

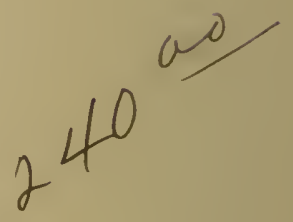

\section{ROCK TERRACE}

Panel: Height, 12 inches; length, 16 inches

A Natural terrace of rocks breaks up sharply from a green meadow in the foreground, its shadowed side lightened with touches of gray. Slender trees form faint traceries against the soft blue and white sky and at the right is seen a stretch of water and trees through a blue haze. 
No. 104

\section{HENRY WARD RANGER, N.A.}

American : 1858-1916

\section{LANDSCAPE}

Millboard: Height, 12 inches; length, 16 inches

A stone wall cuts across the center of the picture, separating the rocky pasture in the foreground from the woodland beyond. A man stands by an opening in the wall and a coollooking blue sky overhangs the landscape.

Signed at the lower left.

No. 105

\section{HENRY WARD RANGER, N.A.}

American : $1858-1916$

\section{WINDY SKIES}

Millboard: Height, 12 inches; length, 16 inches

BEFORE a gusty autmun wind grayish clouds are driven across the heavens. Red-leafed trees make a dull pattern against the sky as they stand on either side of a lonely road running directly away from the foreground.

Signed lozver left and dated. 
No. 106

\section{HENRY WARD RANGER, N.A.}

American : $1858-1916$

\section{FARMHOUSE AND TREES}

Millboard: Height, 12 inches; length, 16 inches

Is the clear light of a brilliant fall day, an unadorned white farmhouse is seen through an open grove of trees, the scanty foliage of which has turned brown, red and yellow. A white cow roots under one of the trees and the meadow in the foreground is in tones of yellow, green and tan.

Signed at the lower left.

No. 107

HENRY WARD RANGER, N.A.

AMericax : $1858-1916$

\section{SPRINGTIME LANDSCAPE}

Millboard: Height, 12 inches; length, 16 inches

Dividing the composition almost in half, a grass grown road runs directly away from the foreground. At the right a stone wall separates it from a meadow where a cow is grazing, while at the left a man is seen in the field. Trees rise up in the center of the picture and frame the background, while eartl and sky are noist with the feeling of springtime.

Signed at the lower left, and dated '96. 
No. 108

\section{HENRY WARD RANGER, N.A.}

Aniericax : $1858-1916$

NOVEMBER

Millboard: Height, 12 inches; length, 16 inches

Pasture burned greenish brown, trees with bare branches and a cool mottled blue sky form the scheme of this simple, impressive painting. A stone-and-post wall runs up and down over the rolling pasture and gray boulders thrust their irregular shapes up through the earth.

Signed at the lower left

No. 109

HENRY WARD RANGER, N.A.

American: 1858-1916

\section{DESERTED ACRES}

Millboard: Height, 12 inches; length, 16 inches

Too rock-strewn for even a New England farmer to work, these deserted acres spread out before the eye, a veritable Noman's land. Hardy grass, weeds and bushes spring up among the lichen-covered rocks and boulders and along the sky line are seen a few trees.

Signed at the lozerer left, and dated 1907. 
No. 110

\section{HENRY WARD RANGER, N.A.}

Anerican : $1858-1916$

\section{A NEW ENGLAND PORT}

Panel: Height, 12 inches; length, 16 inches

A CRISP blue and white sky overhangs a view of Long Island Sound. The shoreward prospect is of a New England port, furnishing the human interest in this charming picture. In the foreground the pale blue water is charged into white as it washes amongst a tumbled mass of brownish red rocks and sedge.

Signed at the lower left, and dated 1910.

No. 111

\section{HENRY WARD RANGER, N.A.}

Americax : $1858-1916$

\section{WOODLAND LANDSCAPE}

\section{Millboard: Height, 16 inches; width, 12 inches}

THE varied coloring of a woodland in the fall season is the raison d'être for this picture. A man is walking through a grove of silver birch trees, gray tree trunks lying on the ground amidst gray rocks, and a carpet of red and yellow leaves. Through the trees is seen a softly brilliant blue and white sky.

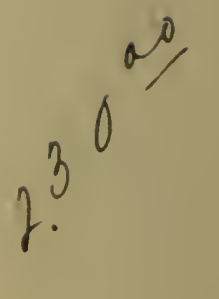



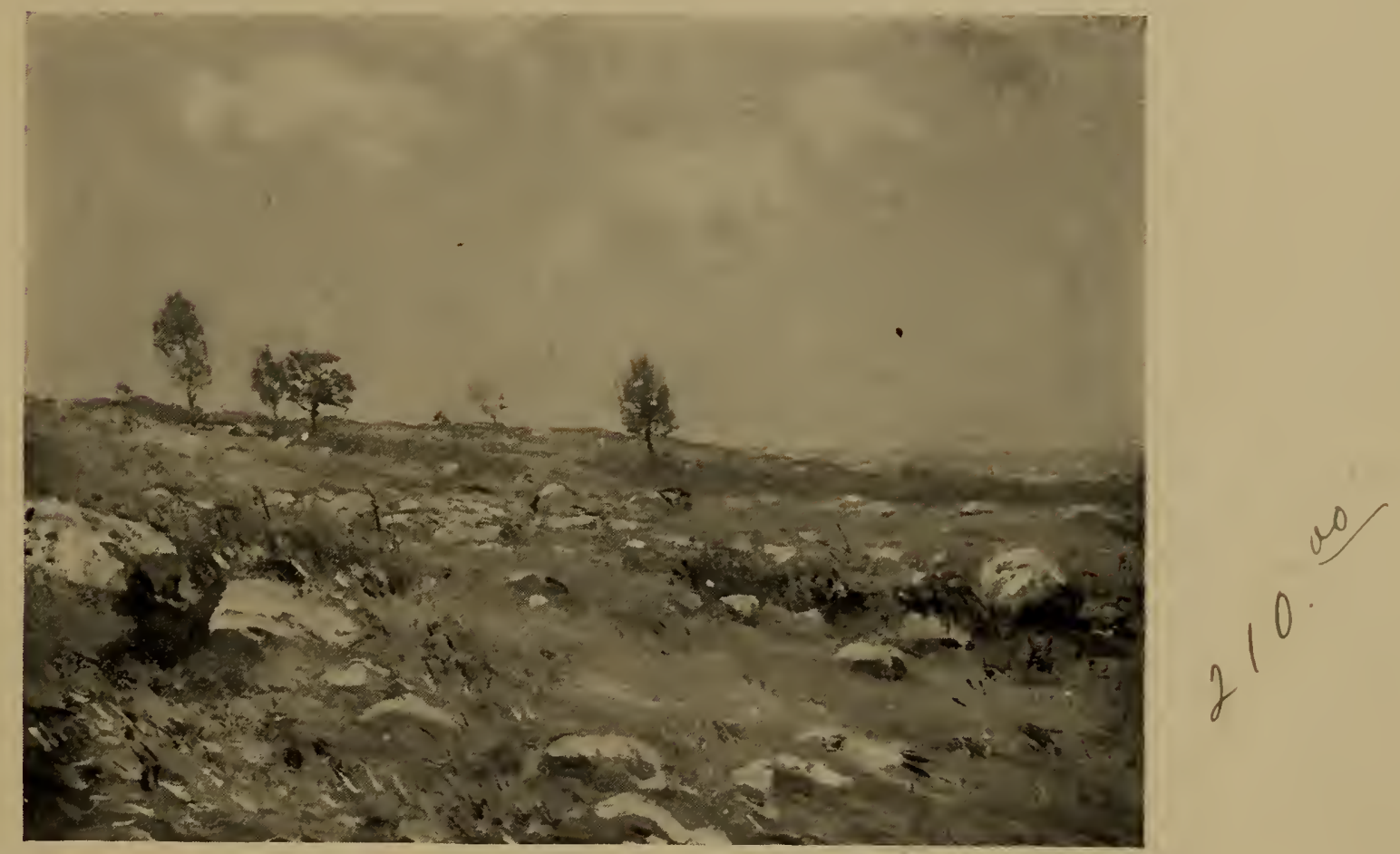

No. 112

\section{HENRY WARD RANGER, N.A.}

Anerican : 1858-1916

\section{SEASIDE MEADOWS}

Panel: Height, 12 inches; length, 16 inches

A RockY meadow land, characteristic of our New England coast, slopes gently up to the left of the picture, its grassgrown surface dotted with boulders, bushes and a few trees. A glimpse of the sea and distant hills is caught at the right. 
No. 113

\title{
HENRY WARD RANGER, N.A. \\ A viericax : 1858-1916
}

\section{AMONG THE BIRCHES}

\author{
ILillboard: Height, 12 inches; length, 16 inches
}

Is a grove of birch trees a man is walking, the sunlight making patches of bright color on the ground and on the tops of the trees seen beyond, above which is a characteristic blue sky with white clouds.

Signed at the lower teft.

No. 114

HENRY WARD RANGER, N.A.

Americax : 1858-1916

\section{A FRESH BREEZE}

Panel: Height, 12 inches; length, 16 inches

A Tonic air sweeps across this view of Fisher's Island Sound, seen from a point of salt meadow in the foreground. Sea and sky are full of crisp motion and the craft passing through the Sound are fecling the effects of the fresh breeze.

Signed at the lower left. 
No. 115

\section{HENRY WARD RANGER, N.A.}

American : $1858-1916$

\section{THE RIVER-MASON'S ISLAND}

Panel: Height, 12 inches; length, 16 inches

A variant of one of Mr. Ranger's most familiar themes. A man is seen rowing a skiff up the "river" in Mason's Island through an opening between the trees springing up from the rocky foreshore. The blue and white of the sky is reflected in the tones of the smooth water.

Signed at the lower left.

No. 116

HENRY WARD RANGER, N.A.

American : $1858-1916$

\section{SLOPING HILLSIDE}

\section{Millboard: Height, 12 inches; length, 16 inches}

From the foreground a rough hillside slopes up and away from the spectator, overhung by a cool blue sky. Gray rocks and boulders dot the soft green stubble, low bushes make lovely notes of color against the green, and a stunted tree is on the brow of the hill. 


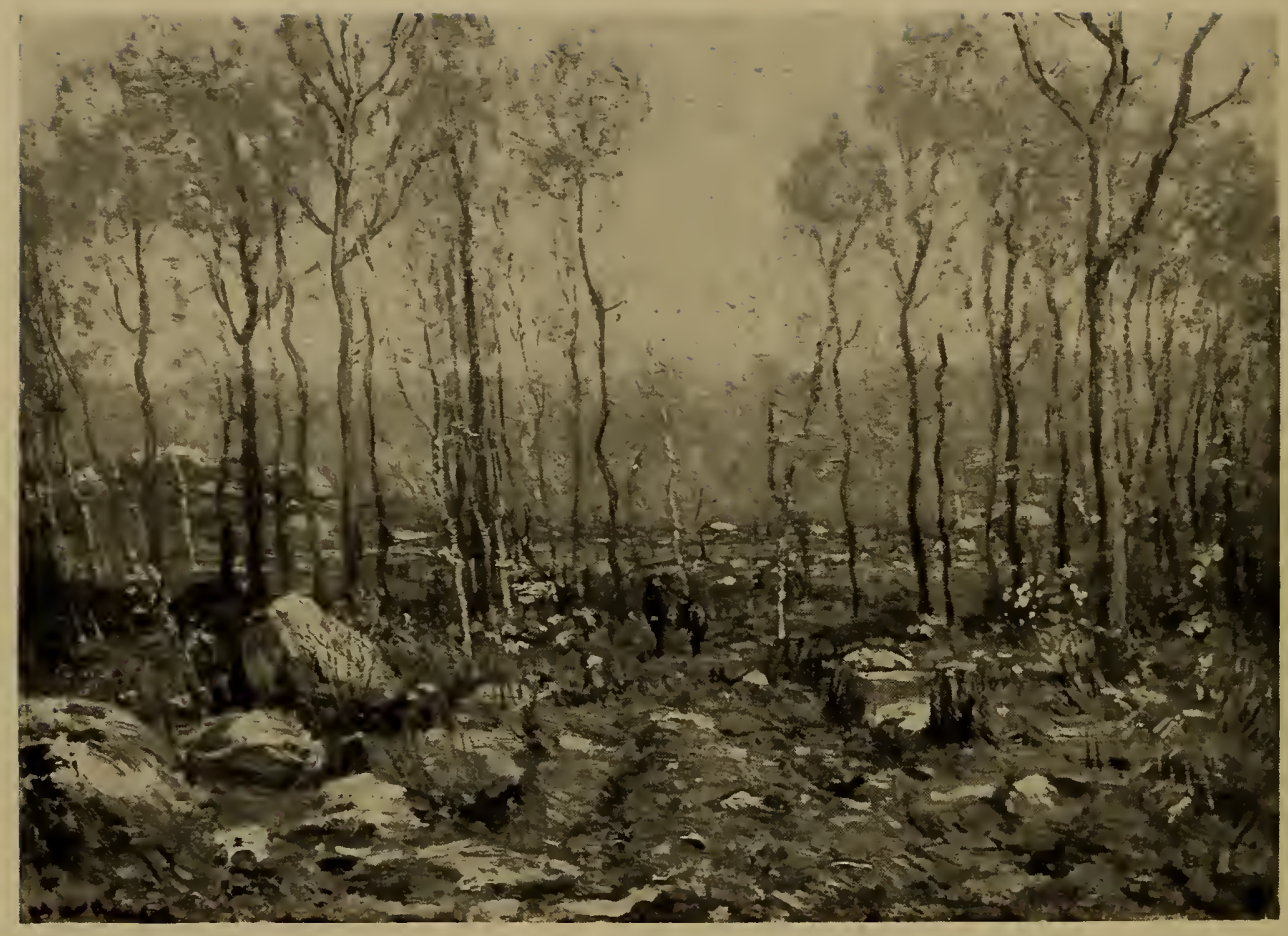

No. 117

\section{HENRY WARD RANGER, N.A. \\ American : 1858-1916}

\section{THROUGH THE WOODS}

Panel: Height, 12 inches; length, 16 inches

Two figures are seen in a rough road that leads through a grove of very slender trees. The tree tops, against the blue sky, show pale russet and the rough ground is dotted with big gray boulders and stones. 
No. 118

\section{HENRY WARD RANGER, N.A. \\ American : $1858-1916$}

\section{ALONG THE SOUND}

Panel: Height, 12 inches; length, 16 inches

A LINE of low grass-grown sand dunes fills the foreground, over the top of which, at the right, is seen the blue water of the Long Island Sound, with a line of breakers marking a bar that runs out from the shore. A white Coast Guard station shows above the dune and in the extreme distance is a redroofed house. A blue sky across which float "smoky" white clouds fills the rest of the picture.

Signed at the lower left.

No. 119

\section{HENRY WARD RANGER, N.A.}

American : $1858-1916$

\section{HILLTOPS AND VALLEY}

Millboard: Height, 12 inches; length, 16 inches

From the left of the picture the straight line of a sloping hill cuts directly across the picture, met more than halfway by a more distant and higher range of hills, whose bare slopes are seen in sunlight, while the lower hill is partly in shadow. The sky, in varied tones of blue, is filled with sunlit white clouds and in the flat valley floor in the foreground are indicated a group of buildings and brush fires. 
No. 120

\title{
HENRY WARD RANGER, N.A.
}

\author{
AMerican : 1858-1916
}

\section{THE BROOK}

Millboard: Height, 12 inches; length, 16 inches

Winding away from the foreground a brook is seen between rough pasture lands at the right, while a clump of low trees fills the whole left of the picture by the streamside. In the distance is a grove of trees. A moist springtime sky rises up to the top of the picture.

Signed at the lower left.

No. 121

\section{HENRY WARD RANGER, N.A.}

Americax : $1858-1916$

\section{MARINE: BLUE AND WHITE}

Millboard: Height, 12 inches; length, 16 inches

A solitary expanse of blue water is tumbled into white-capped waves by the force of a strong breeze that sends gray white clouds driving across the blue sky, the treatment of these two simple colors being the great charm of the picture.

Signed at the lower left. 


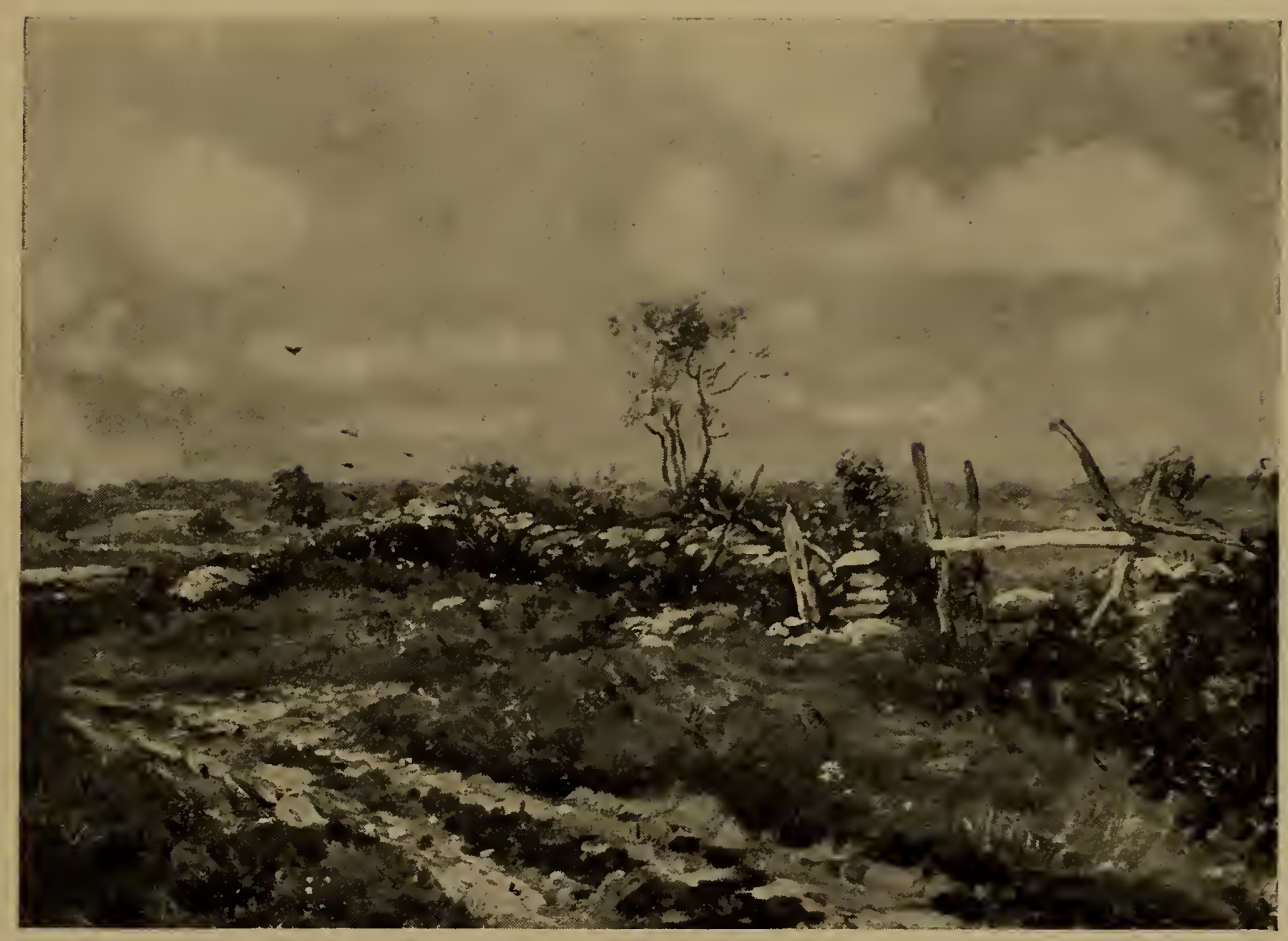

No. 122

HENRY WARD RANGER, N.A.

American : $1858-1916$

\section{$O L D S A N D R O A D$}

Millboard: Height, 12 inches; length, 16 inches

Is the foreground an old sand road runs toward a salt water cove, seen in the distance, by the side of a stone wall overgrown with weeds and bushes. A few saplings swept almost bare of foliage are in the center of the picture, rising up against a characteristic Ranger sky. 
No. 123

\section{HENRY WARD RANGER, N.A. \\ American : 1858-1916}

\section{MARINE: CLEARING OFF}

Height, 18 inches; length, 26 inches

A sHower is seen disappearing at the right of the canvas, leaving a mass of sun-touched white clouds across the scene partly obscuring the blue sky. Below stretches a flat expanse of green sea with white sails in the distance and a solitary fisherman in a skiff at the right.

No. 124

HENRY WARD RANGER, N.A.

American : $1858-1916$

\section{WILLOWS IN SPRINGTIME}

Height, 18 inches; length, 26 inches

UNDER the clear light of a springtime sky a river runs through

flat meadows with willows on either bank. Two men are in a boat at the right of the composition and behind them rises the smoke of a brush fire. In the foreground is a shadowy green meadow with a group of willows thrusting their slender branches up against the sky. 


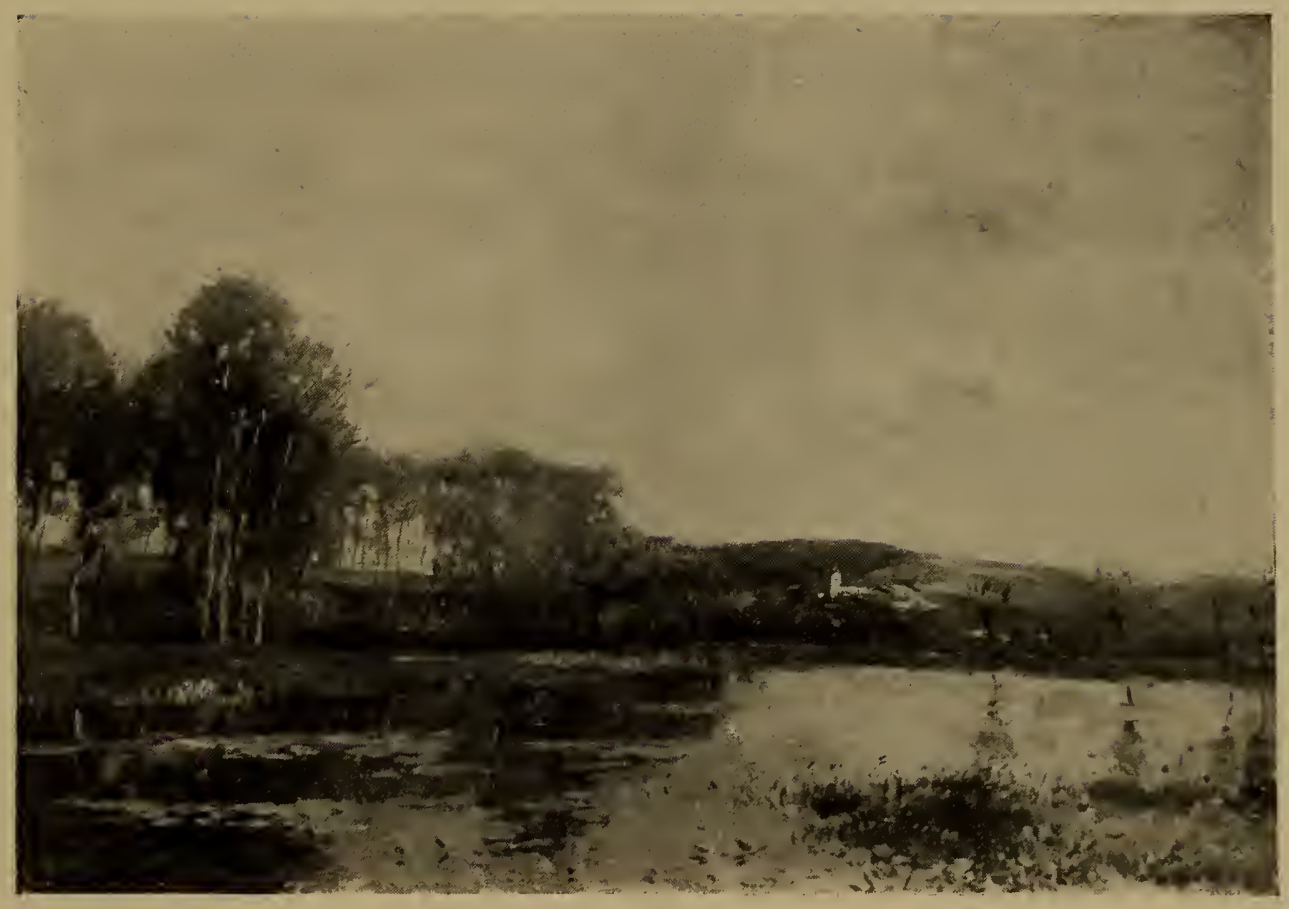

No. 125

HENRY WARD RANGER, N.A.

A MERICAN : $1858-1916$

\section{LANDSCAPE AND STREAM}

Height, 18 inches; length, 26 inches

A QUIET river flows in the foreground between flat meadows of pale green. At the left a thin grove of trees fills the view under the blue and white summer sky. At the right a hill rises and the white spire of a church makes a note of sharp color against its green and russet slope. 


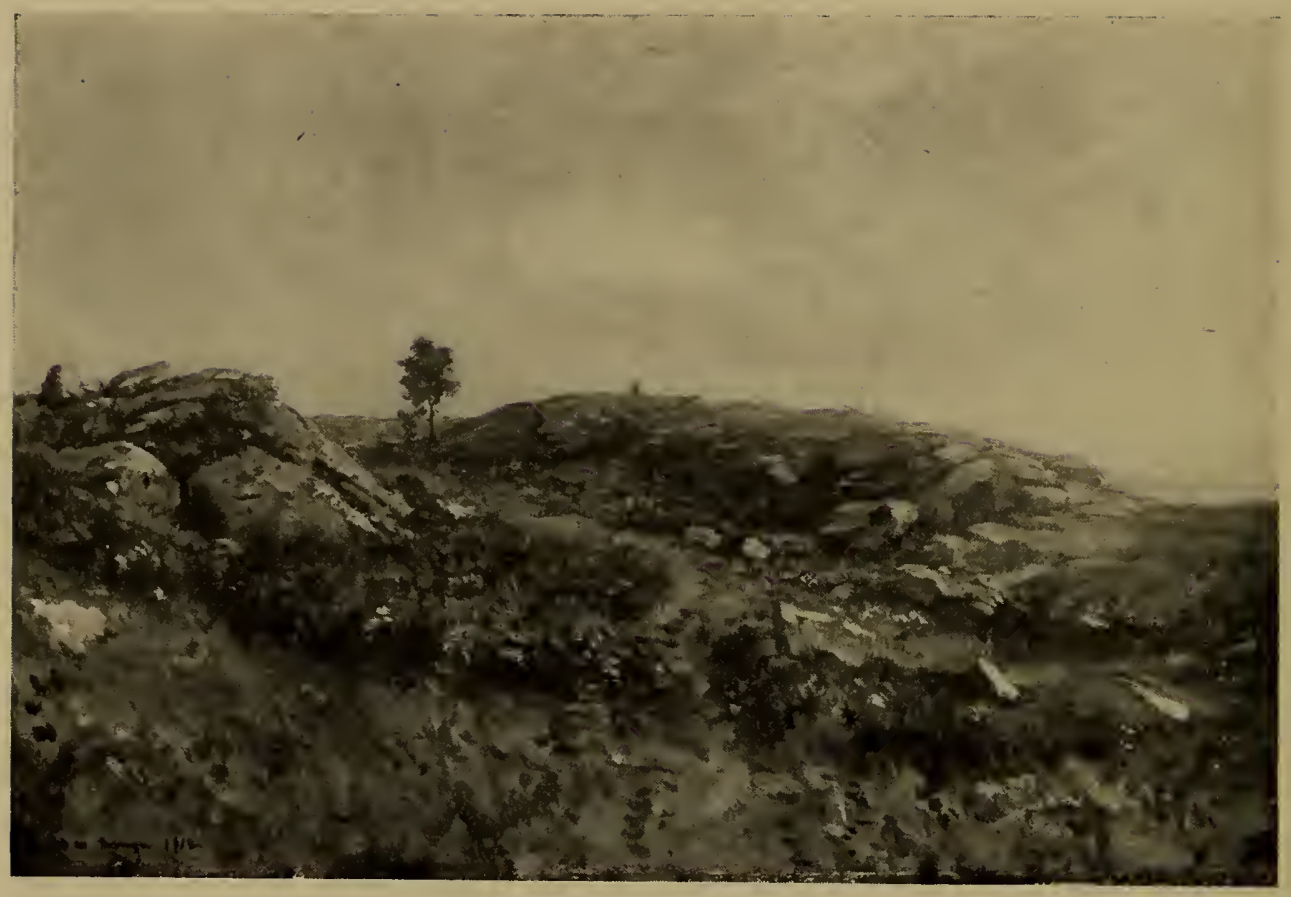

No. 126

HENRY WARD RANGER, N.A.

American : $1858-1916$

\section{LANDSCAPE-ALONG THE COAST}

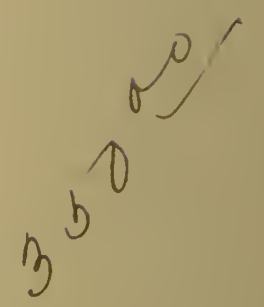

Height, 18 inches; length, 26 inches

A TYPICAL bit of wild land such as lies along the New England coast with brown and russet weeds springing up among the coarse grass and a ledge of outcropping boulders forming a colorful mass at the left. Beyond is a long, rounded hillock of rocks and earth. A lonely tree and a bit of the sea is at the extreme right. 
No. 127

\section{HENRY WARD RANGER, N.A.}

American : $1858-1916$

\section{THE RIVER}

Height, 18 inches; length, 26 inches

A WINDY sky ranging in tones from gray down to palest green hangs over a Netherlands river. Near at hand at the left are craft of various kinds along the bank and on the stream a tug is towing a bark upstream. Three windmills are seen on the farther low bank of the river.

Signed at the lower left, and dated '92.

No. 128

\section{HENRY WARD RANGER, N.A.}

American : $1859-1916$

\section{MARINE: CALM WEATHER}

Height, 18 inches; length, 26 inches

Is the hot light of a midsummer day sailboats lie at anchor off a Long Island Sound village that is seen in the distance through the heat haze. A buoy makes a definite red note in the center of the picture, but all else, water, sky and land, is in pale tones of blue and white and green.

Signed at the lower left, and dated 1906. 


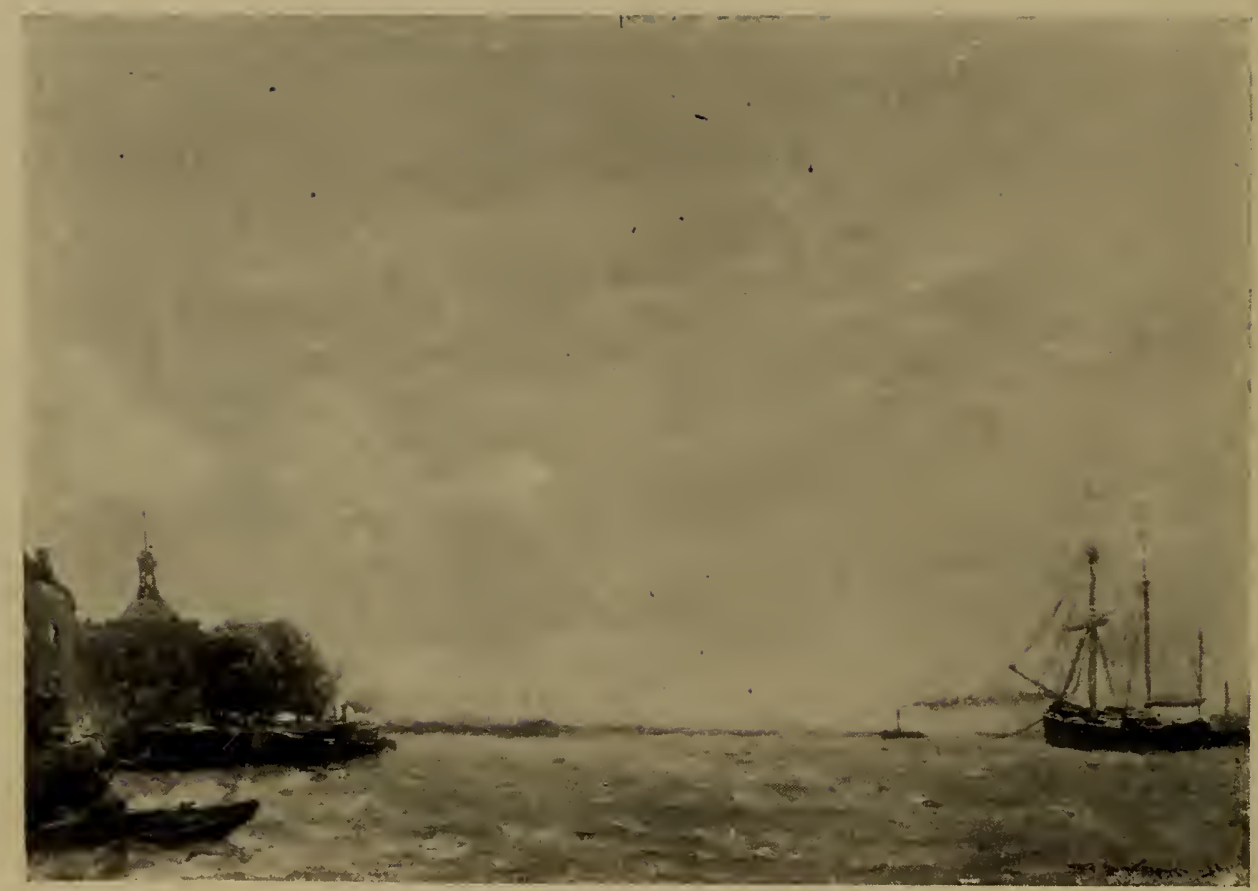

No. 129

\section{HENRY WARD RANGER, N.A.}

AMERICAN : 1858-1916

\section{HOLLAND RIVER SCENE}

Height, 18 inches; length, 26 inches

THE center of the picture is filled with the roughened waters of a Dutch river up which a tug is towing a two-masted vessel. In the distance is the low river bank, while at the left is shown the riverside edge of a town with boats along the quays and buildings and trees bulked against the gray white clouds.

Signed at the lower right, and dated '91. 


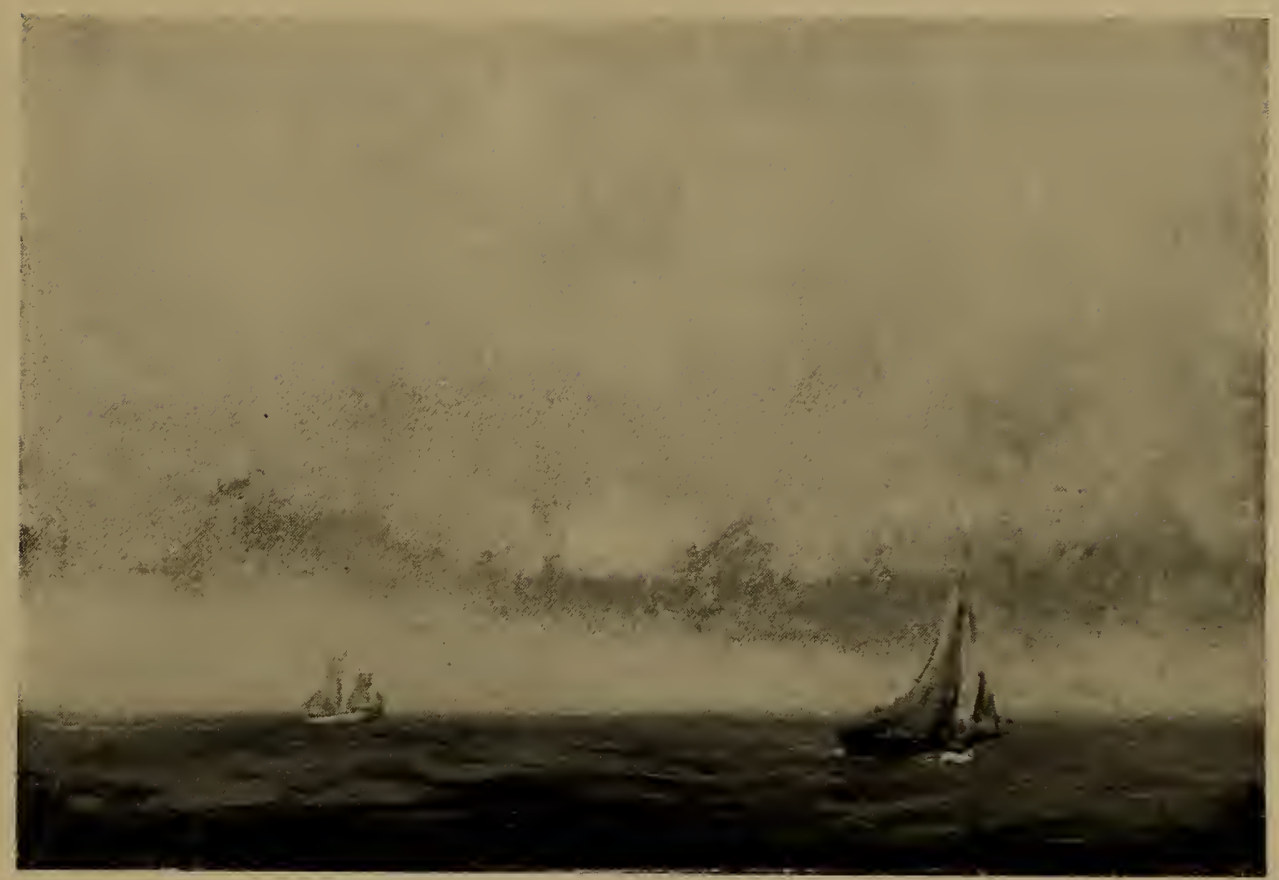

No. 130

HENRY WARD RANGER, N.A.

A merican : $1858-1916$

\section{THREATENING WEATHER}

Height, 18 inches; length, 26 inches

BEFORE a stiff blow that is sending heavy greenish gray and white clouds down towards the horizon a black sloop and a white schooner are driving across a heavy expanse of ocean, empty save for them. Foam breaks along the bow of the sloop, making a sharp note of white in the dull blue-green sea.

Signed at the lower left, and dated 1908. 
No. 131

\section{HENRY WARD RANGER, N.A.}

AMERICAN: $1858-1916$

\section{A GOOD HARBOR}

Height, 18 inches; length, 26 inches

THE quiet waters of a bay lie between two flat points of land between which a white sailed boat is seen running into harbor. A schooner and a few other boats lie at anchor off a fishing village at the right and another schooner is at the left. Gray and white wind clouds fill the sky overhead.

Signed at the lower left.

No. 132

\section{HENRY WARD RANGER, N.A.}

American : $1858-1916$

\section{CLOUDS AND SUNSHINE}

Height, 18 inches; length, 26 inches

A DESOLATE stretch of boulder strewn dune land runs down to the sea that is seen in the distance. From a depression in the foreground, with a pool of water, the ground slopes up on either side. A solitary tree stands on the right, while a great boulder is on the left. Rain clouds overhead cast shadows on the foreground, but the view beyond lies in bright sunlight. 


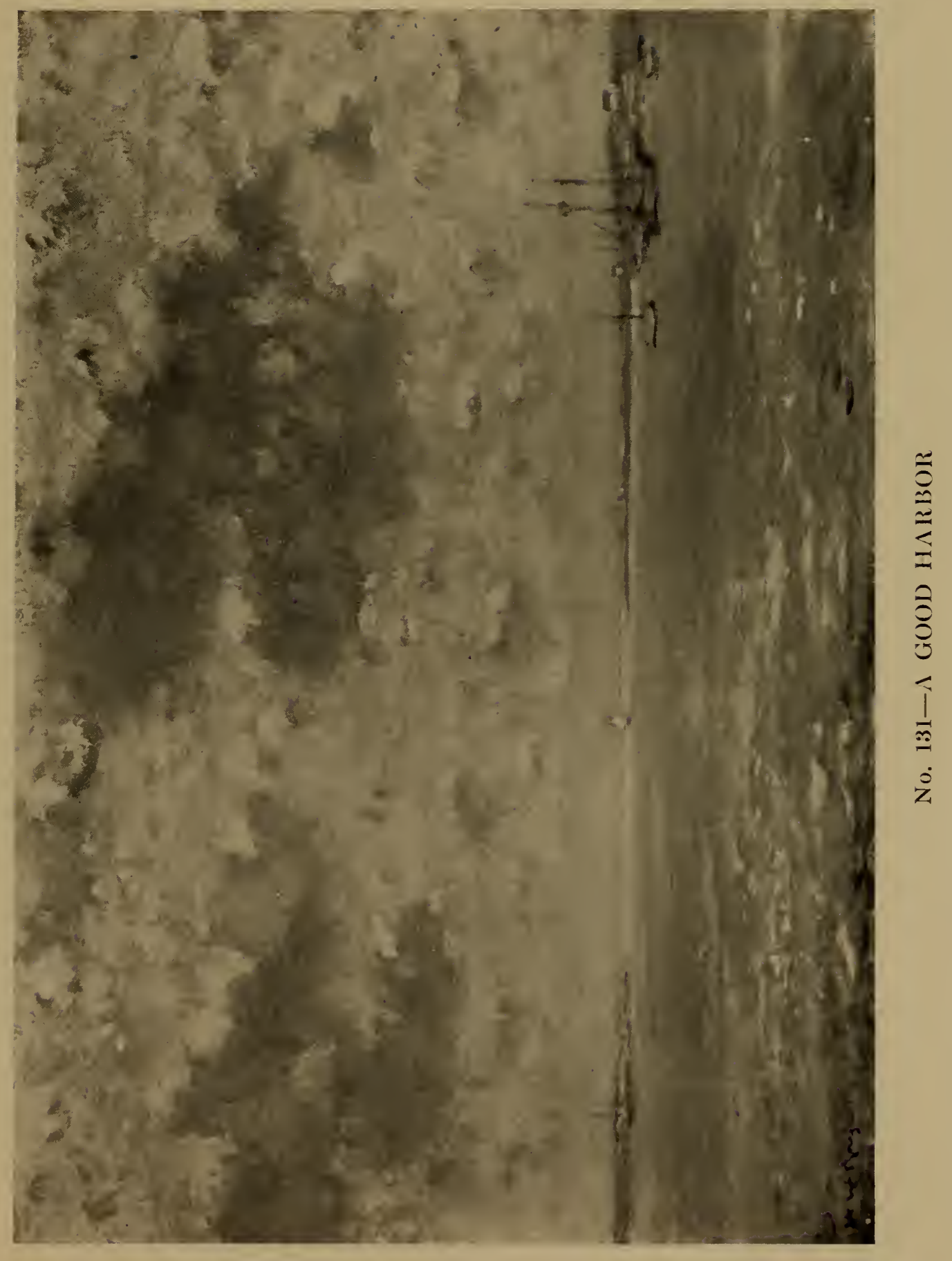


No. 133

\section{HENRY WARD RANGER, N.A.}

American : $1858-1916$

\section{AUTUMN'S GLOW}

Height, 18 inches; length, 26 inches

From a blue and rose sky the sunlight filters through a line of trees along the bank of a stream on to the rippled waters, painting its surface with pink and blue and russet hues. The foliage of the trees is autumn red and on the stream is a redshirted fisherman in an ancient punt.

Signed at the lower left, and dated '97.

No. 134

\section{HENRY WARD RANGER, N.A. \\ American : 1858-1916}

\section{NOANK, CONNECTICUT}

Height, 28 inches; length, 36 inches

ThE maritime activities of the artist's home town are represented in this canvas under one of those gorgeous sunset skies that impelled his brush so often. A shipyard with two schooners on the stocks is shown at the right, with men working among floating logs in the foreground, and behind them rises factory buildings with smoke rising up into the hot windless sky. At the left becalmed schooners are grouped in picturesque confusion. 


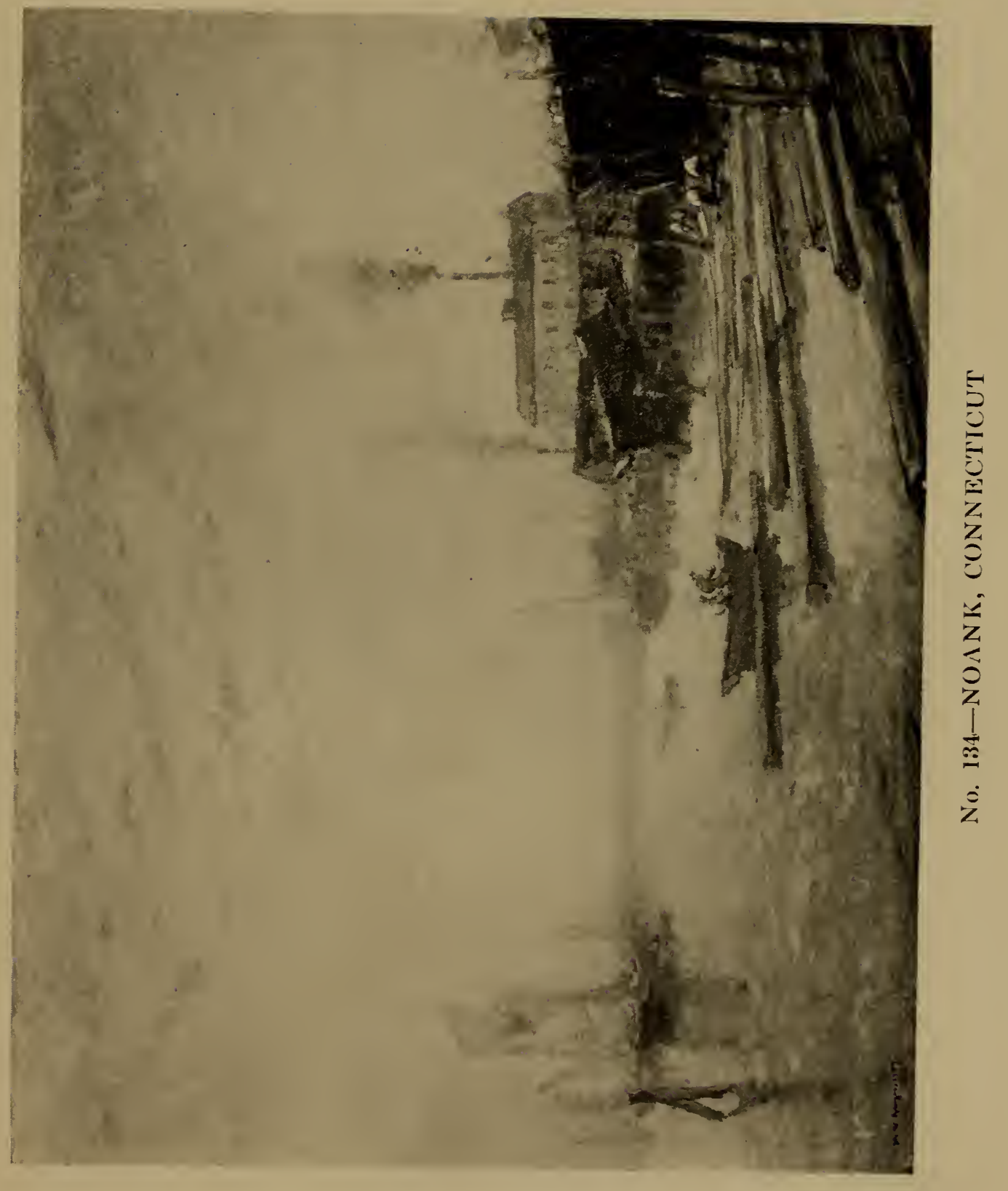


No. 135

\section{HENRY WARD RANGER, N.A. \\ American: $1858-1916$}

\section{THE ARCHED TREES}

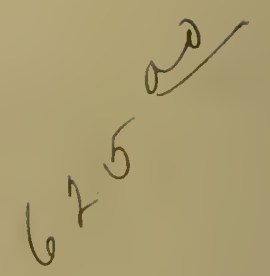

Height, 28 inches; length, 36 inches

Through a natural arch formed by the interlacing branches of two trees in the foreground one sees a broad meadowland in the full light of the afternoon sun. Yellowish white clouds float over the distant view, while overhead is a deep blue sky. A pool is in the foreground and at the edge of the thicket of trees are two figures.

No. 136

HENRY WARD RANGER, N.A.

AMERICAN : 1858-1916

\section{AUTUMN WOOD INTERIOR}

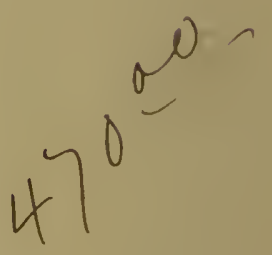

Height, 28 inches; length, 36 inches

A patters of vivid autumnal coloring is worked out here with old and young trees against a glorious blue sky. Bright sunlight falls on tree trunks and foliage and in the shadowed foreground two figures are roughly indicated. This is one of the last pictures Mr. Ranger painted in the summer of 1916 . 


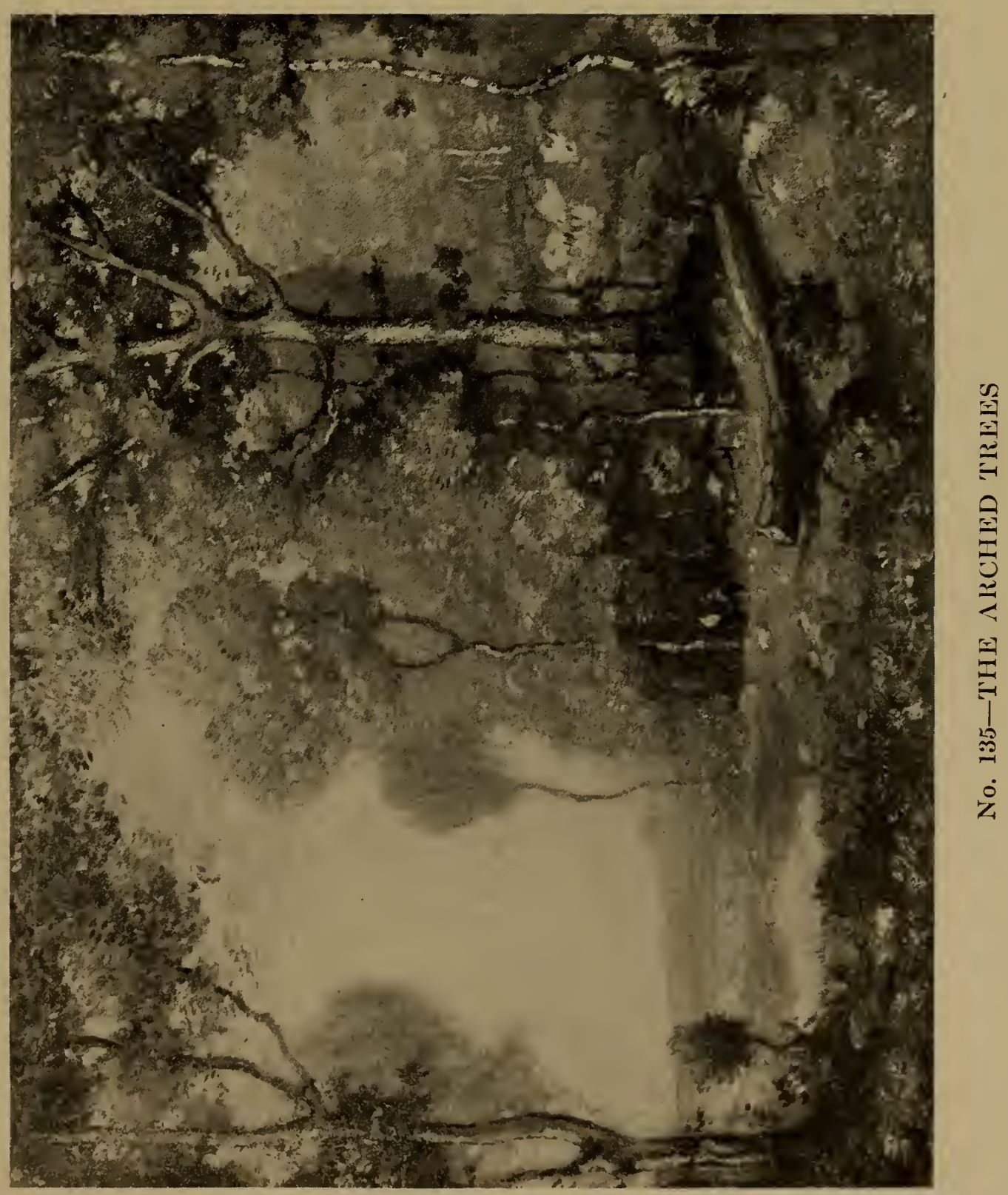




\section{$\Varangle$ HENRY WARD RANGER, N.A.}

A Merican: $1858-1916$

\section{TREES AND MEADOW}

\section{Height, 28 inches; length, 36 inches}

THE light of a westering sun gleams out of a blue, cloudflecked sky through the branches of trees curving from the right foreground slightly towards the center of the view. A low stone wall runs across the foreground and with the trees encloses a partly shadowed meadow that stretches away to the horizon. At the left figures are seen, and beyond houses are indicated. This is one of the last pictures Mr. Ranger painted in the summer of 1916 .

No. 138

HENRY WARD RANGER, N.A.

AMERICAN : 1858-1916

\section{HILLTOP ROAD}

Height, 25 inches; length, 30 inches

From the foreground a rough cart road leads directly away from the eye across a rough upland pasture to disappear orer the top of the hill that dominates the scene. Lichen-covered rocks and a stunted red bush are in the pasture, a low stone wall crosses the foot of the hill and runs along the left edge of the hill. Two feathery green trees make notes of color against the blue and white sky. 


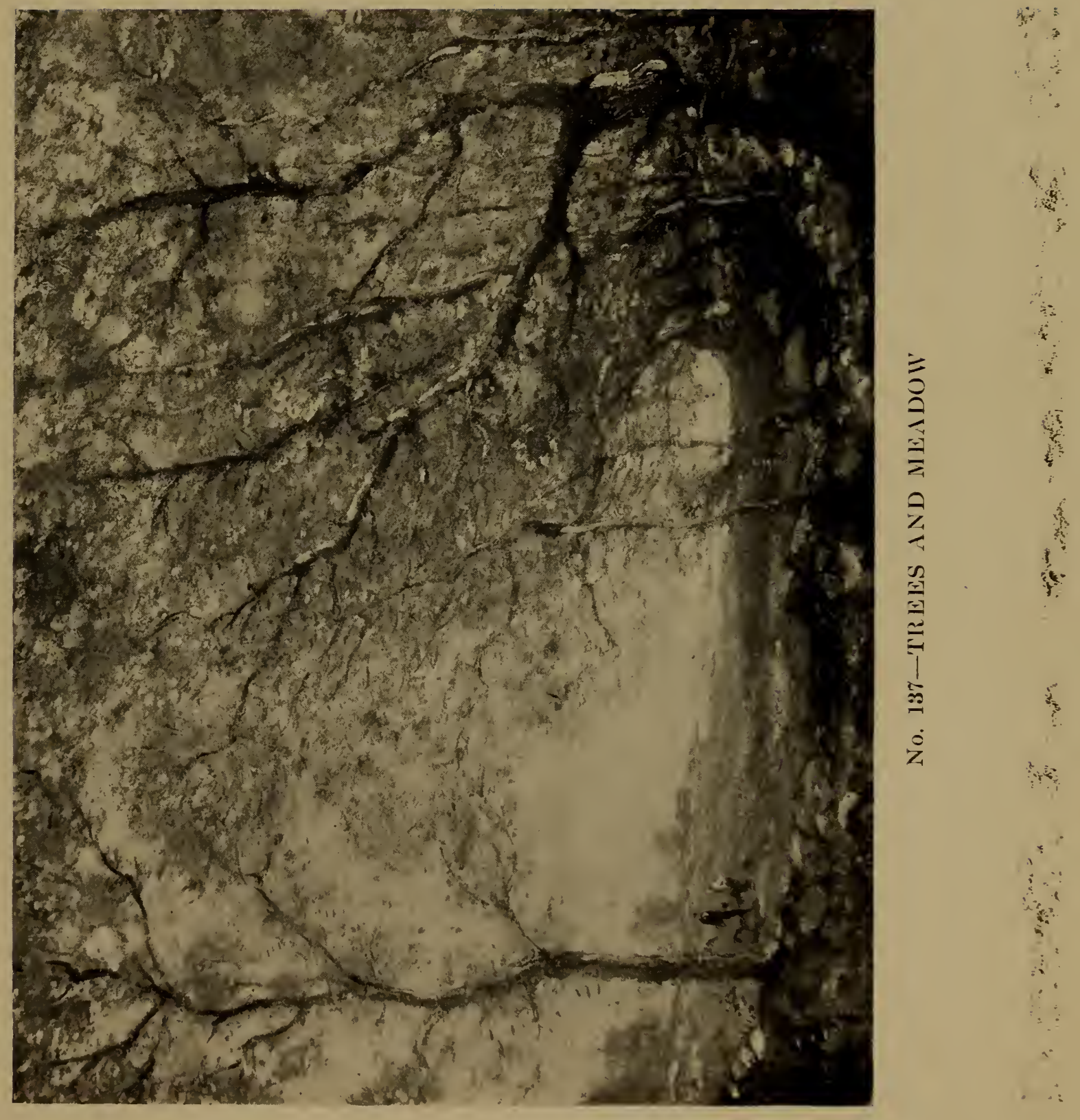


No. 139

\section{* HENRY WARD RANGER, N.A.}

Americhis : 1858-1916

\section{EARLY SPRING}

Height, 28 inches; length, 36 inches

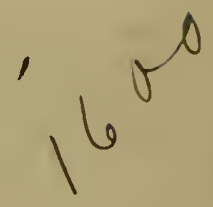

Silyer birch trees and saplings spring up from the overgrown shore of a pond in the foreground, their green leafed branches forming a delicate screen through which one sees the clear still waters of a pond, a tender blue and white sky and the distant shore beyond. A man in a fishing skiff adds a human note to the scene. One of the pictures painted by the artist in the summer of 1916.

Signed at the lower left.

No. 140

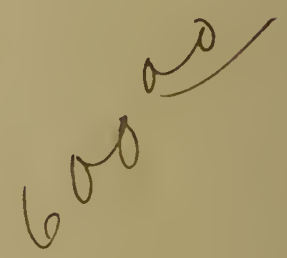

\section{HENRY WARD RANGER, N.A.}

Americax : $1858-1916$

\section{EARLY MORNING ON THE SOUND}

Height, 28 inches; length, 36 inches

An old coasting schooner drifts slowly toward the spectator over a calm green sea that reflects the hot color of the sunflushed sky. Two distant craft make notes of color on the horizon from where the sky rises, pale green and gold, to the upper heavens where float fleecy clouds touched with pale red. 


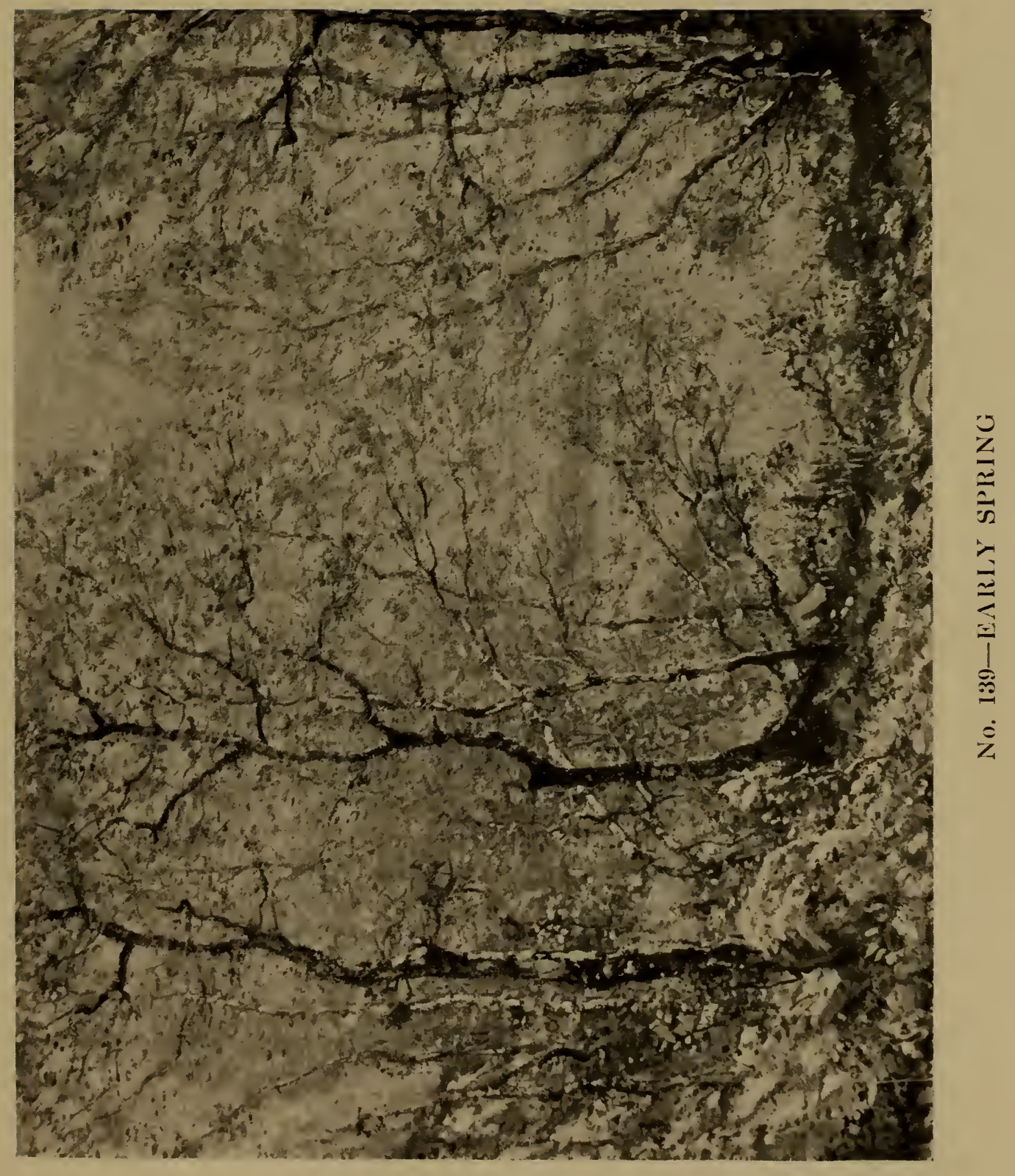


No. 141

\section{HENRY WARD RANGER, N.A. \\ Anerican : 1858-1916 \\ THE EDGE OF THE VILLAGE}

Height, 36 inches; width, 28 inches

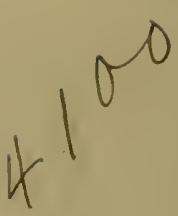

One of the last pictures painted by Mr. Ranger in the summer of 1916. At the immediate edge of a New England village is a grove of trees, two of its number being the chief objects in the picture and framing the vista through which one sees the village, trees, and the hot afternoon sky beyond. Two figures are at the foot of the tree at the left and a green bank slopes down to a pool in the foreground that reflects sky and trees.

No. 142

\section{HENRY WARD RANGER, N.A. \\ A Mierican : $1858-1916$}

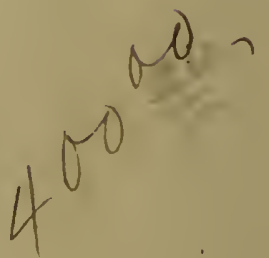

\section{BOW BRIDGE, MOONLIGHT}

Height, 28 inches; length, 36 inches

From the center of the picture in the foreground a deeply rutted road curves across the low bridge of the title which crosses a moonlit stream. Greenish blue mists rise up from the rolling meadow beyond and the green-blue sky, clear save toward the zenith, is filled with the nimbus-like rays from a full August moon. 


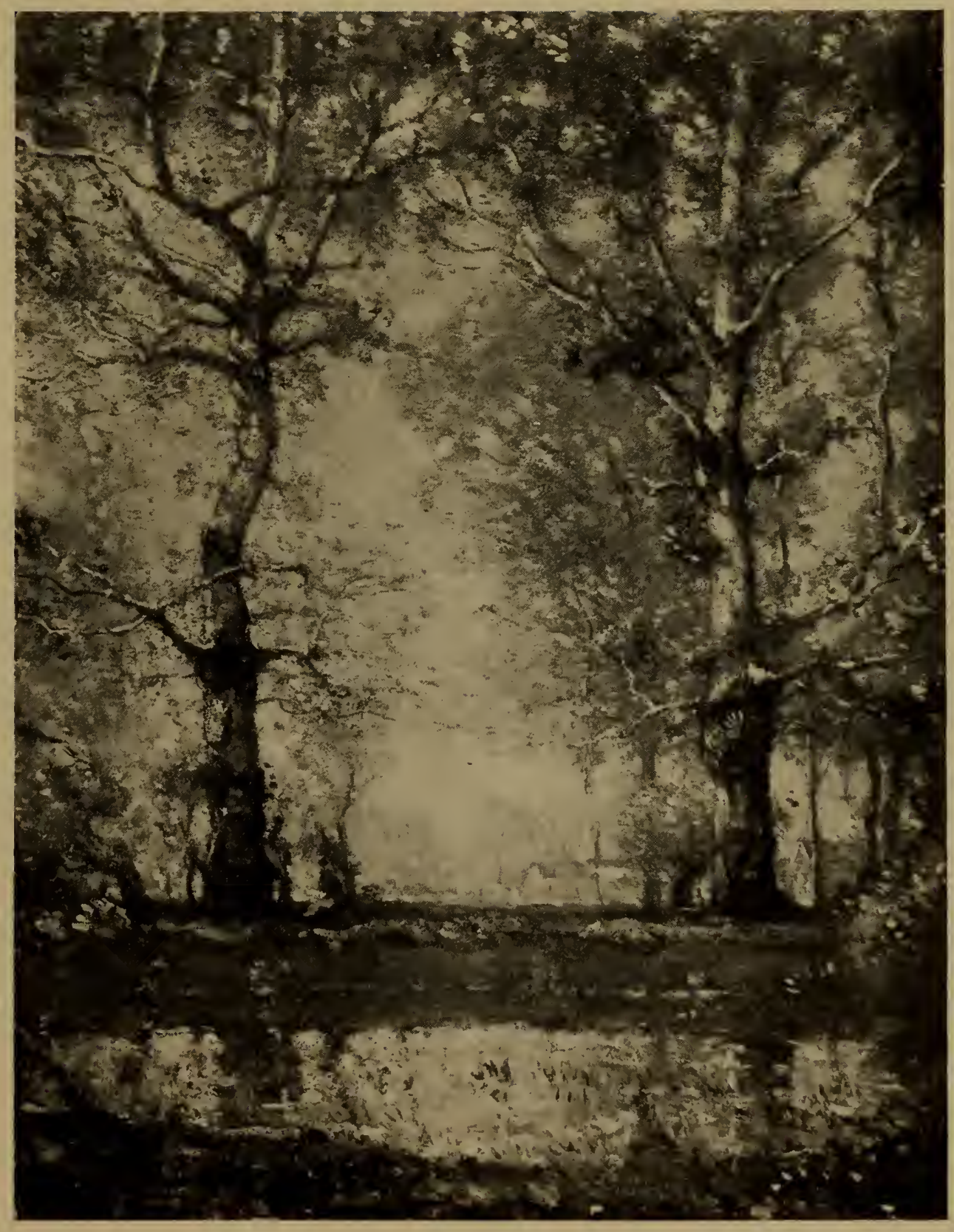

No. 141-THE EDGE OF THE VILIAGE 
No. 143

\section{HENRY WARD RANGER, N.A.}

A Merichy : $1858-1916$

\section{THE WOOD LOT}

Height, 28 inches; length, 36 inches

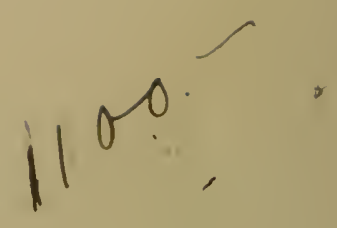

THE woodsmen have cut all the trees and underbrush away so that a clearing in the wood is presented to the eye between two trees at the right and left in the foreground. The earth is covered with a matting of autumn leaves, cordwood is piled up in the clearing and behind is seen a thin grove of trees in autumn hues. A brilliant bright blue sky completes this glowing scene.

Signed at the lower left.

No. 144

HENRY WARD RANGER, N.A.

Americax : 1858-1916

\section{THE PATH THROUGH THE WOODS}

Height, 28 inches; length, 36 inches

A MAx on horseback emerges from the woods along a path approaching the spectator. The foreground is partly in shadow and partly in sunlight, and a small pool of water to the right reflects the patch of blue sky overhead. The trees on either side of the opening have donned their autumn vesture, and their trunks are old and gnarled. Dark clouds cover the left portion of the sky, their edges tinged with sunshine. Save for an occasional speck of blue the sky is massed with clouds. 


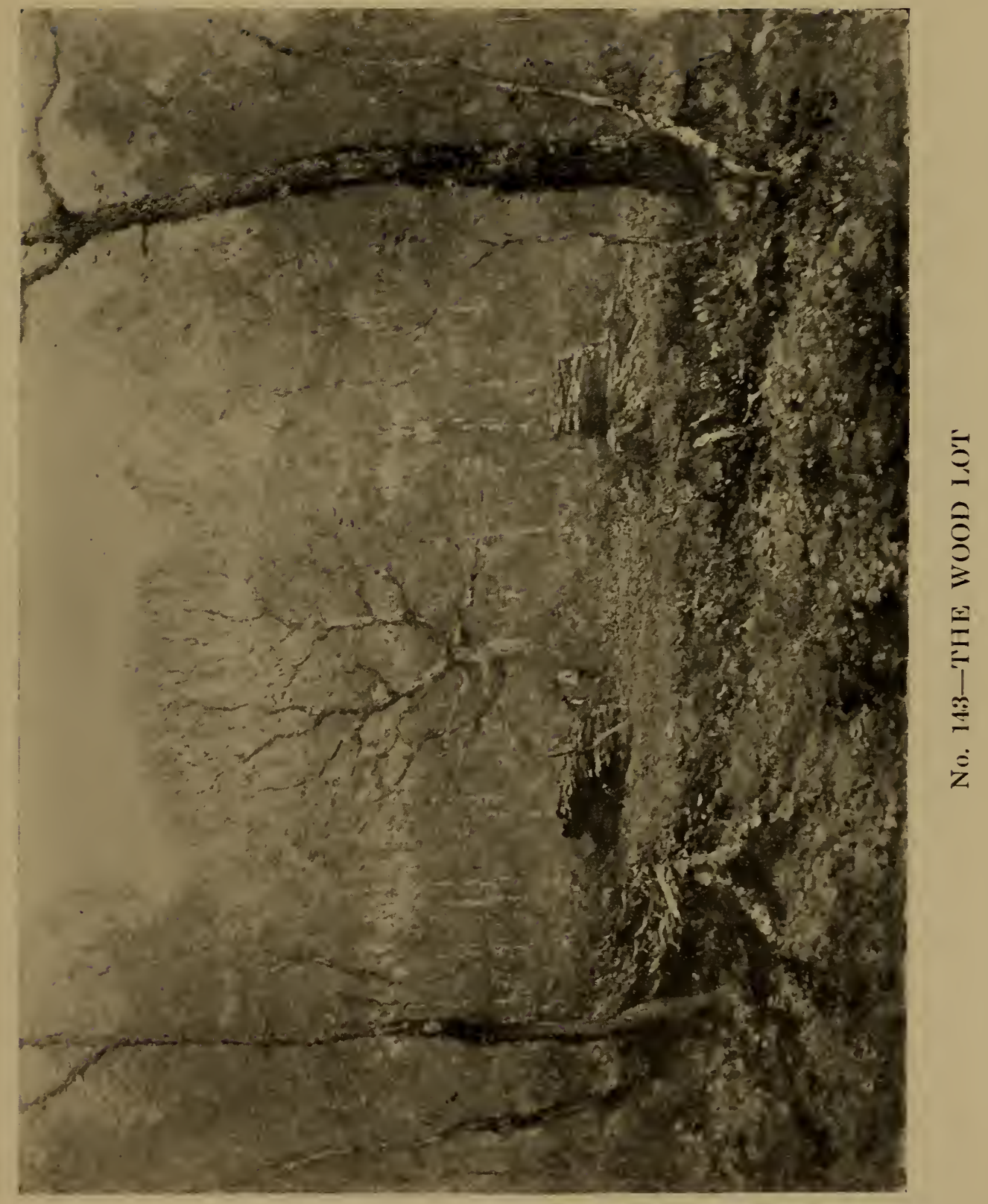


No. 145

\section{HENRY WARD RANGER, N.A.}

American : $1858-1916$

\section{THROUGH THE TREES}

Height, 28 inches; length, 36 inches

ThE trunks, branches and leafage of two trees in the immediate foreground form a screen through which the spectator sees a wide river, the opposite banks of which are lined with the houses of a New England town. At the left below the branches is seen a man in a red skiff, and at the right figures are standing on the river bank, where silver birches fill the right of the canvas. The air is ablaze with summer-day light.

No. 146

HENRY WARD RANGER, N.A.

American : $1858-1916$

\section{BEFORE THE DAYLIGHT IS GONE}

Height, 30 inches; width, 25 inches

Out of a greenish blue sky barred with night-shadowed clouds a rising moon shines down on the waters of the Sound, its trembled reflection reaching to the immediate foreshore. Whitesailed boats dot the surface of the water toward the horizon and at the left a schooner lies at anchor with her mizzen sail hoisted. 


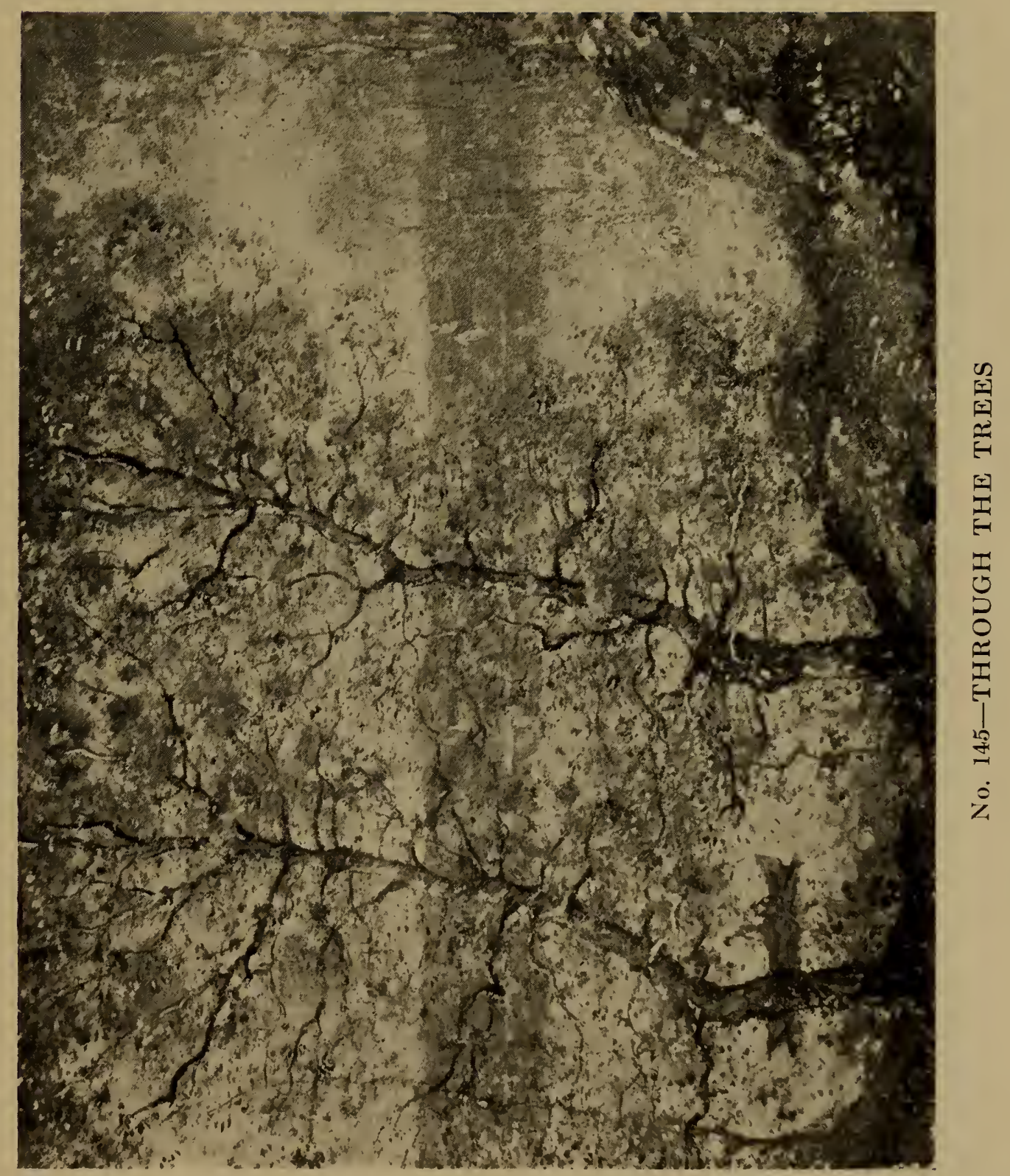


No. 147

\section{HENRY WARD RANGER, N.A. \\ Anericax : $1858-1916$}

\section{OCTOBER LANDSCAPE}

Height, 28 inches; length, 36 inches

A FARMhouse stands at the right of the foreground, sheltered by the trees around it, which shed their foliage in the chill autumn weather. A large log lies in front of the house and a man is cutting off its branches. To the left the trees are tinged a brownish-yellow, and in the opening between these trees and the house the landscape stretches away in the distance. The sky is clouded over and is pale and cold. A flock of birds rise from the vicinity of the farmhouse and are silhouetted against the sky.

Signed at left.

No. 148

\section{HENRY WARD RANGER, N.A.}

Americax : 1858-1916

\section{THE QUARRY HILL}

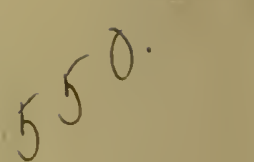

Height, 28 inches; length, 36 inches

From the foreground filled with meadow flowers the eye of the spectator is carried back and upward to the curiously shaped hill of the picture's title that looks as if it might be the burial mound of an enormous giant. A few trees dot the hillside, rocks break through its earthy covering, cows graze on its green carpet. At the left the hill breaks down sharply, showing a thicket of trees. Overhead the blue sky is screened by cumulus clouds through which the sun is "drinking up water." 


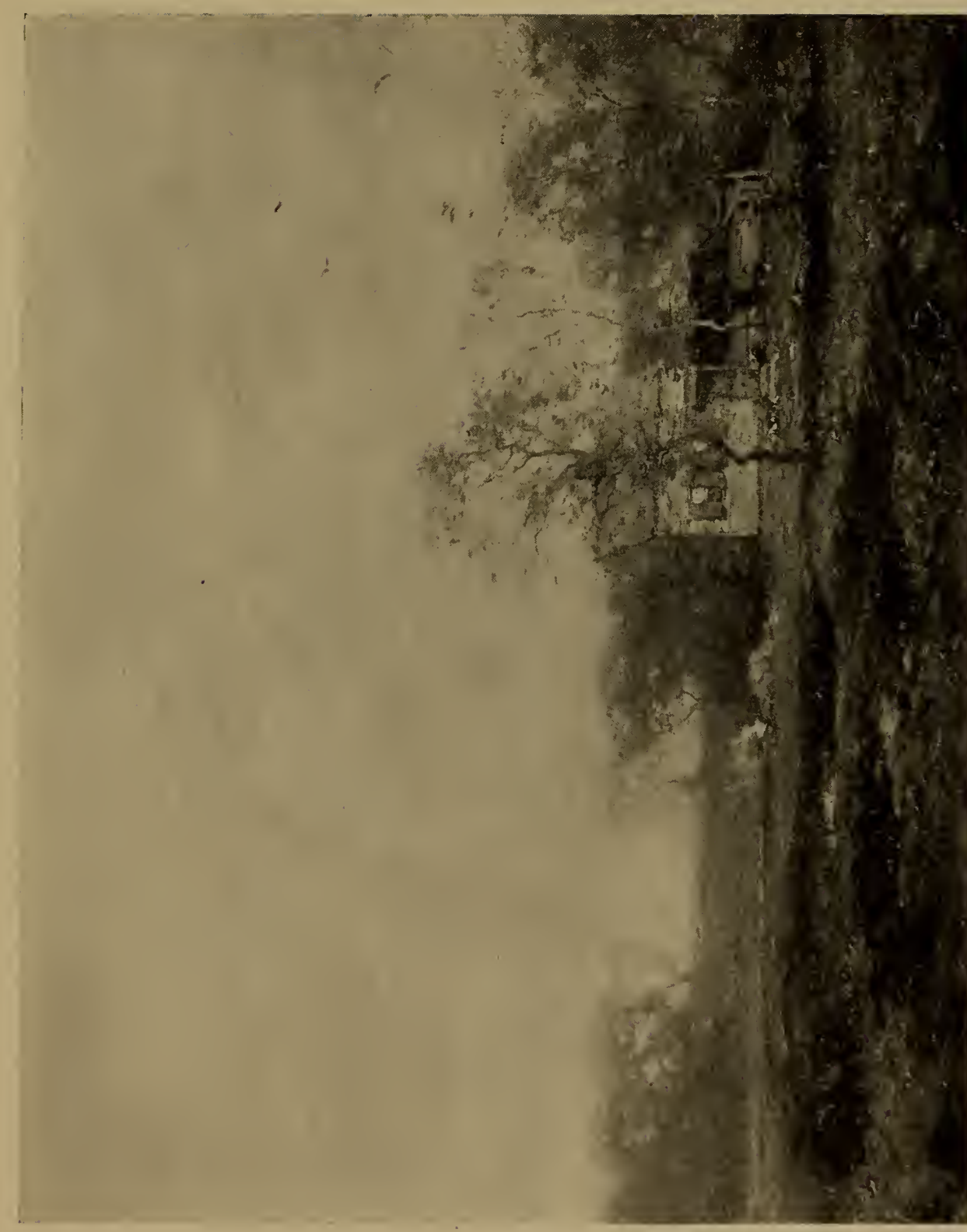

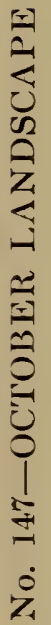


No. 149

\section{HENRY WARD RANGER, N.A.}

A merican : 1858-1916

\section{MISTY AFTERNOON, RATHBURN POND}

Height, 28 inches; length, 36 inches

From a bank on the shore of the pond the spectator looks through an opening between a clump of superbly painted trees to the opposite side of the pond, the distance made seemingly greater by the heat mists. Through the branches a hill rises at the right and over all is a soft blue sky dotted with suntouched clouds.

Signed at the lower left, and dated 1914.

No. 150

HENRY WARD RANGER, N.A.

American : 1858-1916

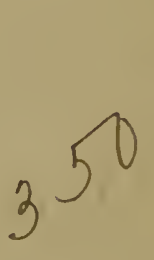

\section{A NEW ENGLAND CHURCH}

Height, 28 inches; length, 36 inches

ThE gable-end of an old New England village church presents its white and red façade to the spectator. The inevitable bluish-green windows accentuate the naive quality of the architecture that combines the practical with touches of a feeling for art in the oddly assorted towers. A tree-lined road leads to its entrance at the left and on a path across the foreground churchgoers are walking. Church and path are on a hillside terrace where, seen through another line of trees, the roof tops of the town and a river show, beyond which a city spreading back from the stream is seen. 


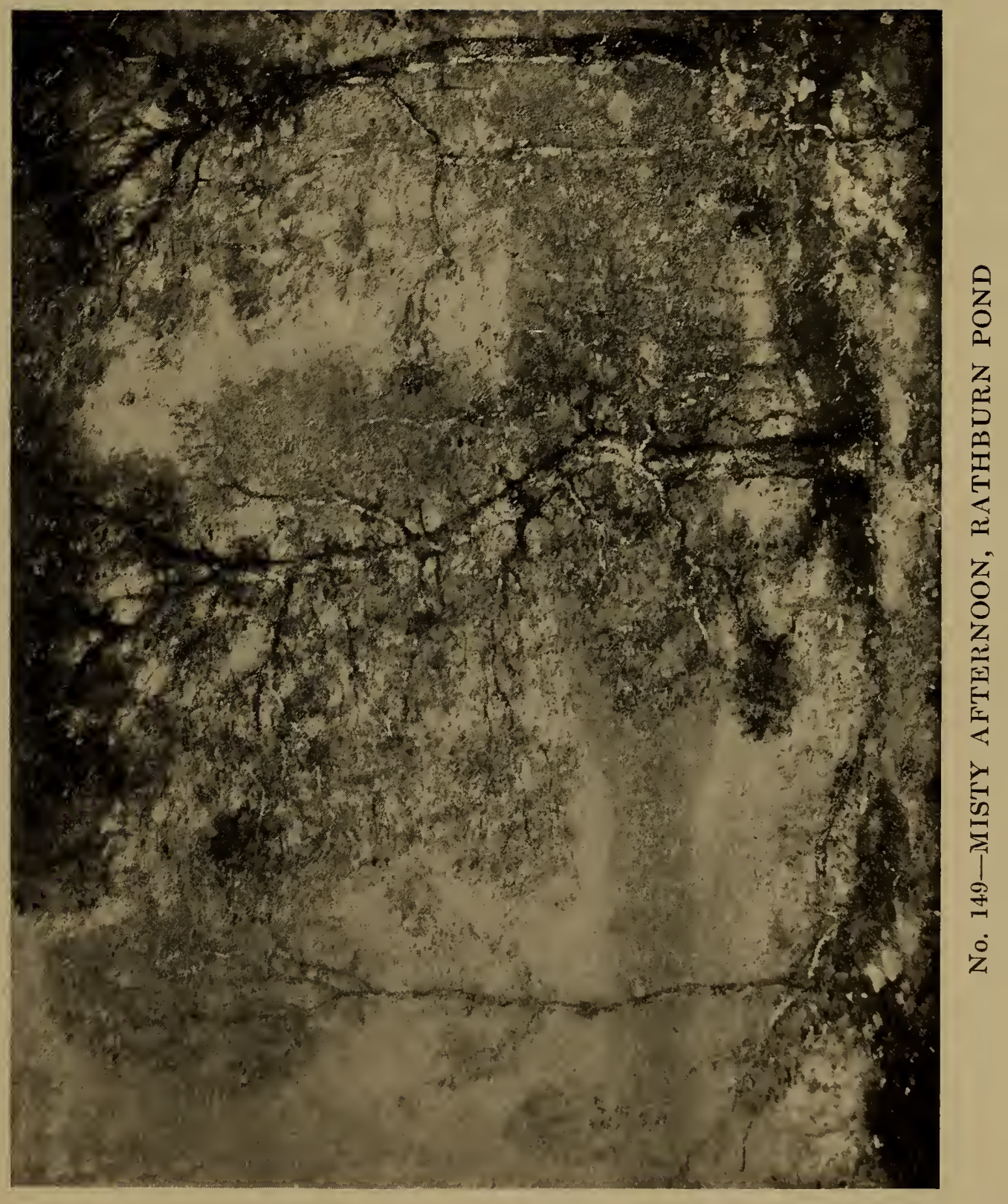


No. 151

HENRY WARD RANGER, N.A.

A Mericax : 1858-1916

TWIN TREES

Height, 36 inches; width, 28 inches

From a lush green meadow dappled with sunlight and shadow rise two trees, their trunks lichen covered, their branches rich with summer's leafage. A blue and white sky is seen through the interstices and beneath the branches is a charming view of a long stretch of water that reflects the hues of the sky. A man sits in a punt on the water and two figures are on the bank by the tree, their shirts adding strong red and blue notes to the brilliant picture.

Signed at the lower left, and dated 1913.

No. 152

\section{HENRY WARD RANGER, N.A.}

Anericax : $1858-1916$

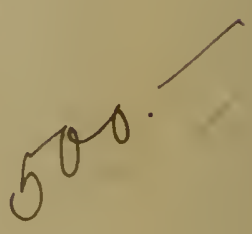

\section{THE WHITE FARMHOUSE}

Height, 28 inches; length, 36 inches

THE tragic note of solitude that rarely appears in Mr. Ranger's pictures is the pervading spirit of this canvas. 'Toward the right, across a flat pasture-land barred with low stone walls, is seen a whitefarmhouse with sharp-pitched roofs of slate gray surrounded by a few stunted trees. At the left is an old barn with faded blue walls. Overhead a mass of whitish gray clouds drives across the heavens before the strong breeze, their expanse dotted with flying crows.

Signed and dated. 


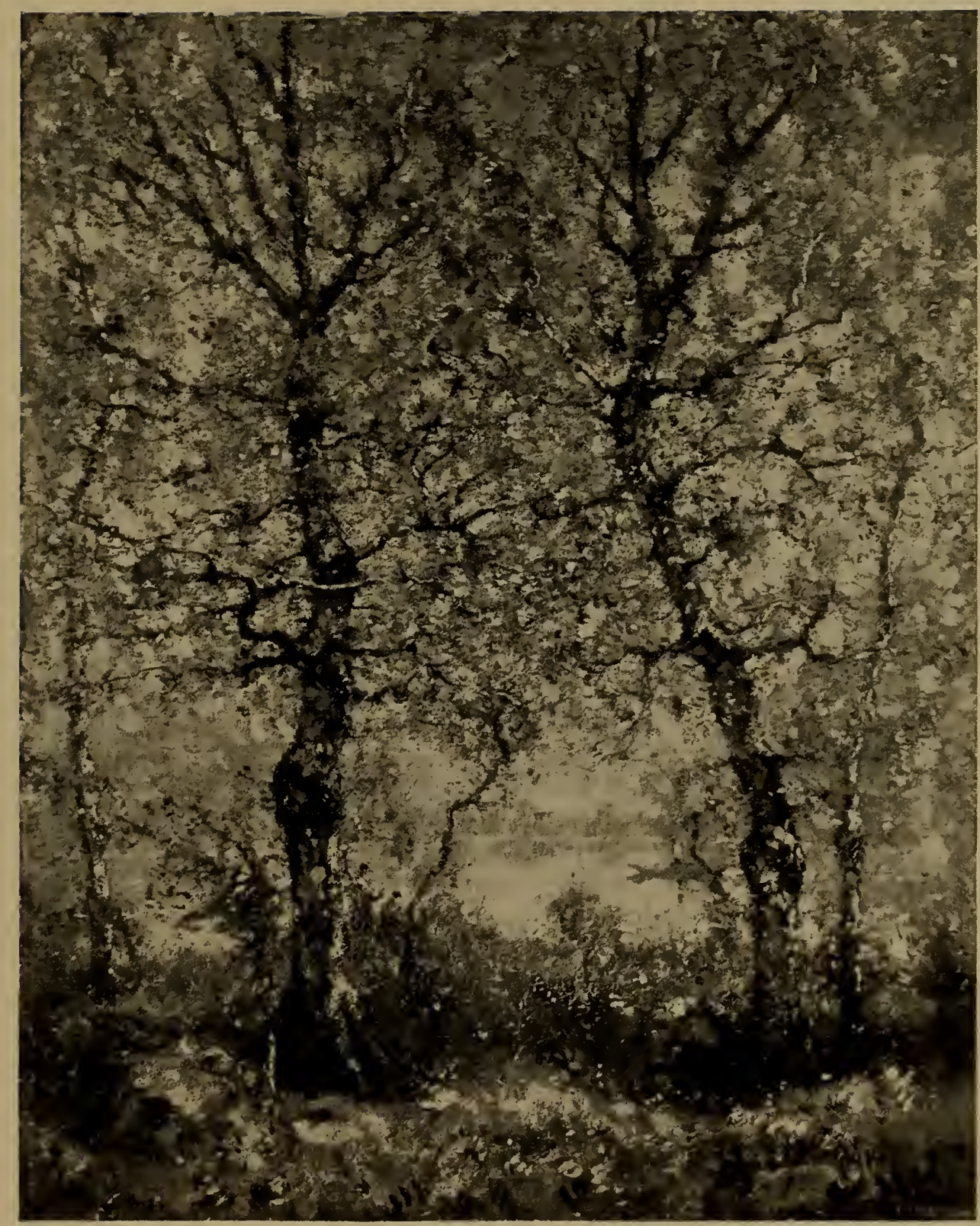

No. 151-TWIN TREES 
No. 153

HENRY IVARD RANGER, N.A.

Americax: $1858-1916$

HEAVY CLOUDS

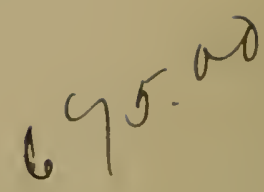

Height, 28 inches; length, 36 inches

A CREEk, the waters of which reflect the blue sky, courses from the marshy foreground to the right along the edge of a heavily wooded pasture. A boat with a sail is drawn up at a landingplace under the trees, and a man sits in the stern. In the field at the right is a man on horseback while another leads a horse to the water. A village shows indistinctly on the farther shore. Heary masses of clouds cover a deep blue sky overhead, and toward the horizon the clouds are piled up, reflecting the bright sunlight.

Signed at left.

No. 154

HENRY WARD RANGER, N.A.

Anericas : $1858-1916$

\section{CLOUDS AND SUNSHINE:}

PECONNUCK VALLEY

Height, 28 inches; length, 36 inches

A BROAD stretch of valley reaches from the foreground to a long, low hill in the distance. A few houses stand in the shelter of this hill, and where it slopes to the right some cattle are grazing. The far distance is enveloped in a blue atmosphere. A huge cloud mass mores across the center of the sky, and below, banks of smaller clouds reflecting the sunlight stretch in regular formation. Overhead the clouds are charged with water and cast a deep shadow over the foreground. 


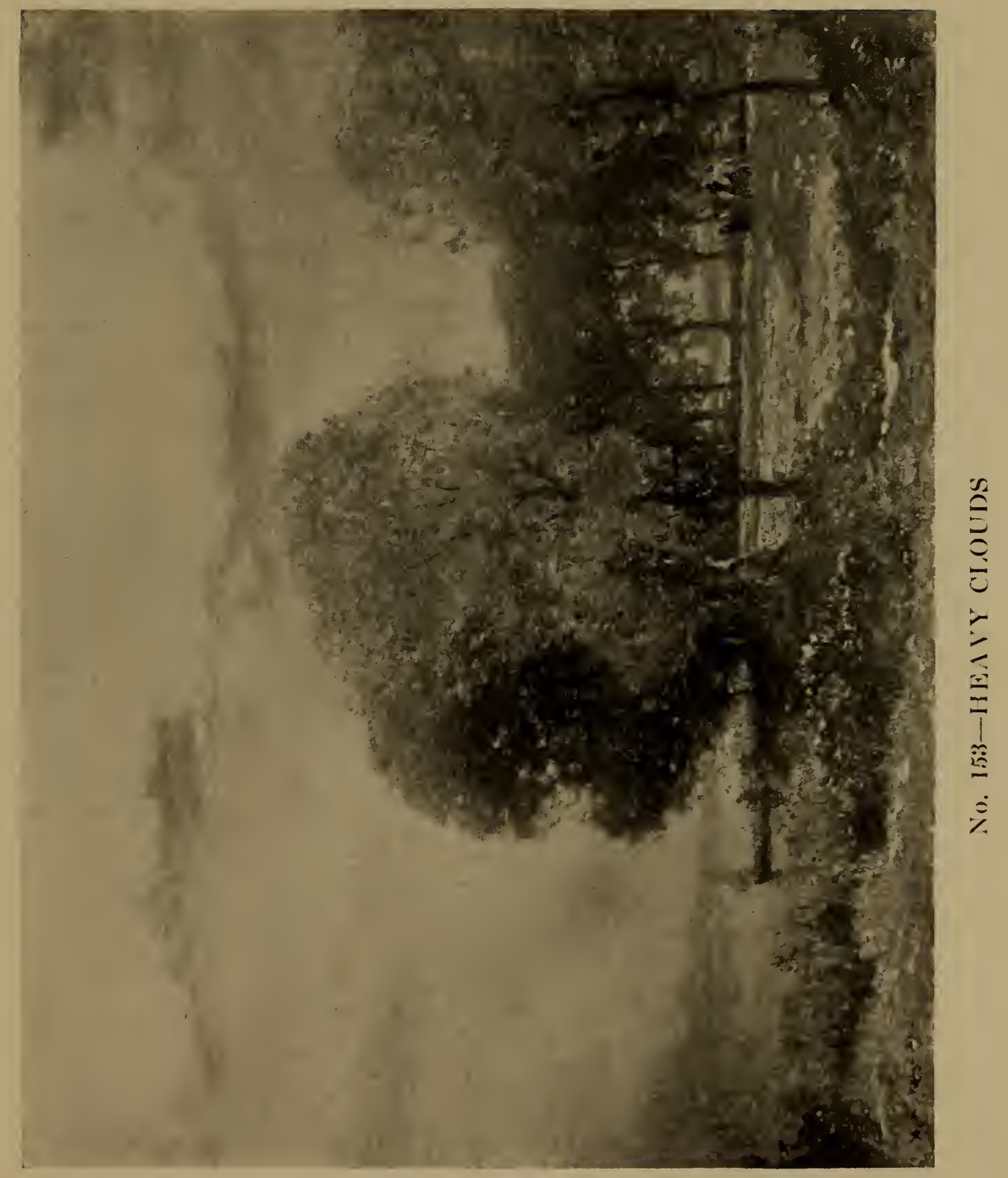


No. 155

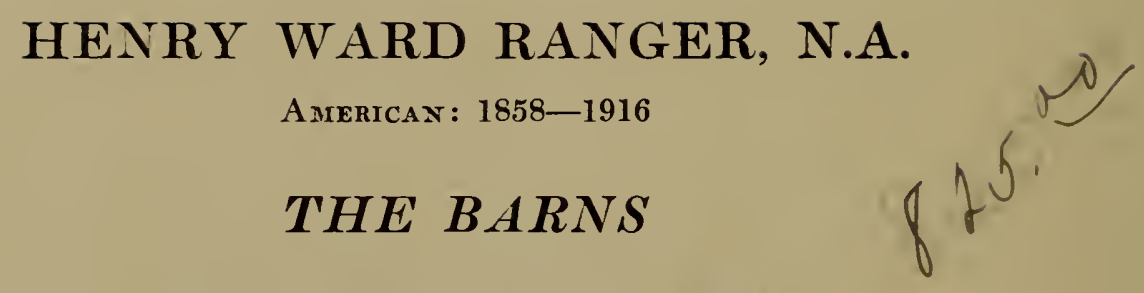

Height, 28 inches; length, 36 inches

The blue waters of a salt creek almost cover the swampy foreground. On the farther edge of this creek two men are standing by a boat drawn up on the landing. In the middle distance are a couple of red barns, and behind these some cattle are grazing. The landscape, except for the immediate foreground, which is in shadow, is bathed in warm sunshine. Cumulus clouds float across a sun-filled sky, and where they break the sky shows blue between them.

Signed at left. 


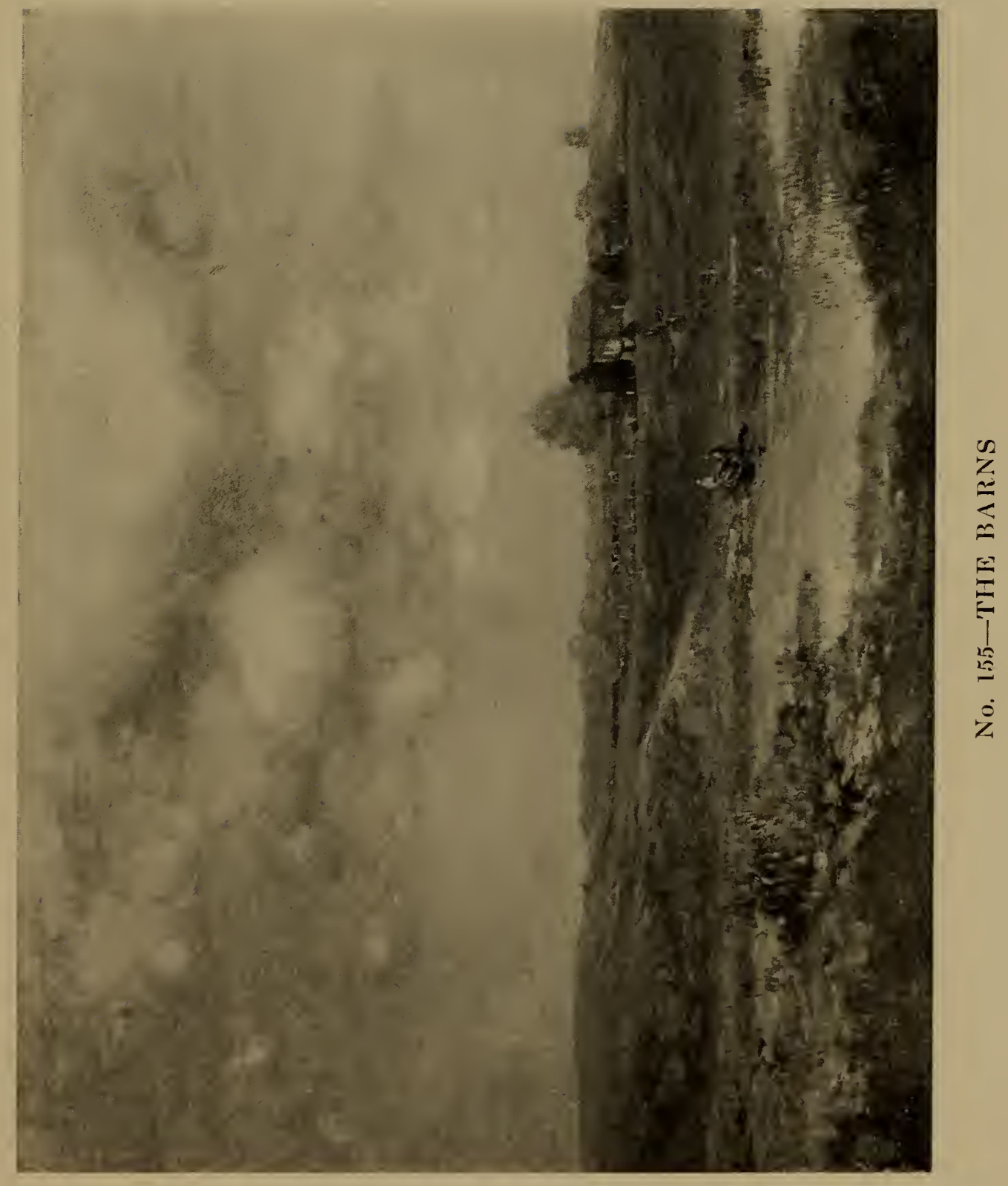


No. 156

\section{HENRY WARD RANGER, N.A. \\ AMErican : 1858-1916}

\section{MOONLIGHT AND STARSHINE}

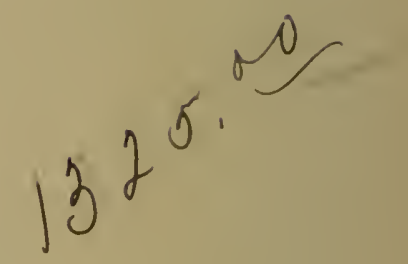

Height, 28 inches; length, 36 inches

Out of a rich blue sky dotted with brilliant stars and crossed by clouds touched with red, pink, and pale green lights glows a summer moon at its full. It shines down on a vista between two groves of trees, two isolated members of which lift their feathery heads up against the glowing sky at the right. A causeway crosses the opening between the groves, on either side of which are seen pools of water reflecting moon and sky.

Signed at the lozer left. 


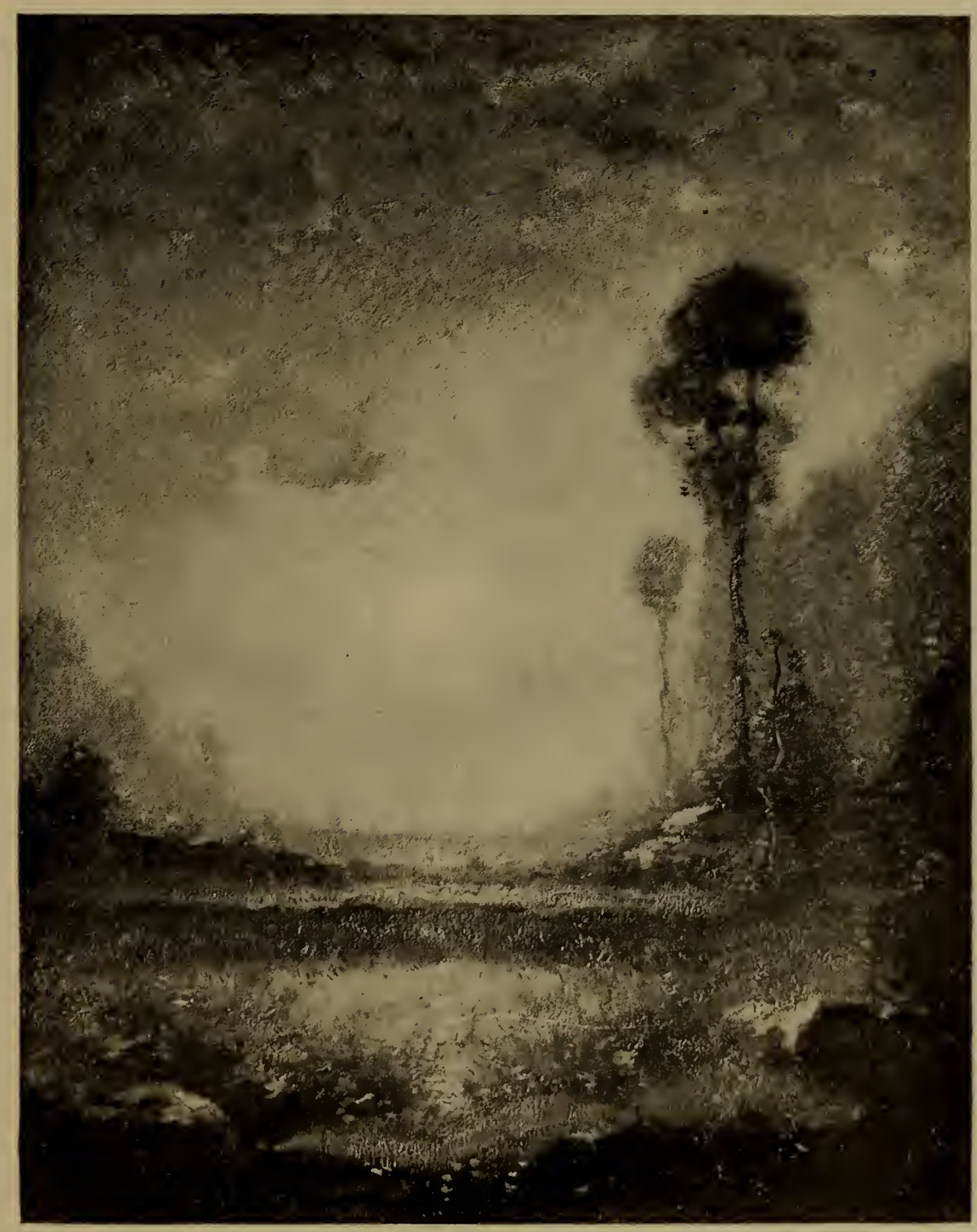

No. 156-MOONLIGHT AND STARSHINE 


\section{HENRY WARD RANGER, N.A.}

Anierican : $1858-1916$

\section{SALT MEADOWS}

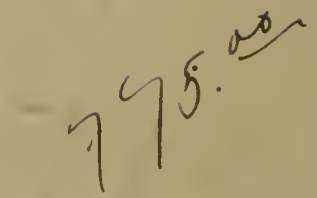

Height, 28 inches; length, 36 inches

A CREen runs across the entire composition, separating the foreground from the land beyond. At the left of the foreground a slender tree is growing, its leaves turned yellow, and at the right some men are working in the meadow. On the farther side of the creek cows are grazing by the water's edge, and beyond these a house with whitewashed walls shows through a group of oaks, their foliage turned to an autumn brown. A huge mass of white clouds occupy the center of the sky, which is a grayish-blue, fading to a nebulous tone as it nears the horizon.

Signed at left.

No. 158

HENRY WARD RANGER, N.A.

Americax : $1858-1916$

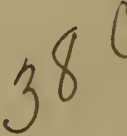

\section{CORNFIELD: LYME, CONN.}

Height, 28 inches; length, 36 inches

STACKED sheares of corn, interspersed with orange-colored squash, standing on the side of a stubbly hill, form the subject of this picture. A low stone fence across the hill, and an old weather-beaten tree struggling for existence, divide this field from a rock-ribbed pasture at the right. A flock of birds rise skyward from the cornfield. Thick cloud masses lie across the sky, which is a pale turquoise where the clouds are broken. 


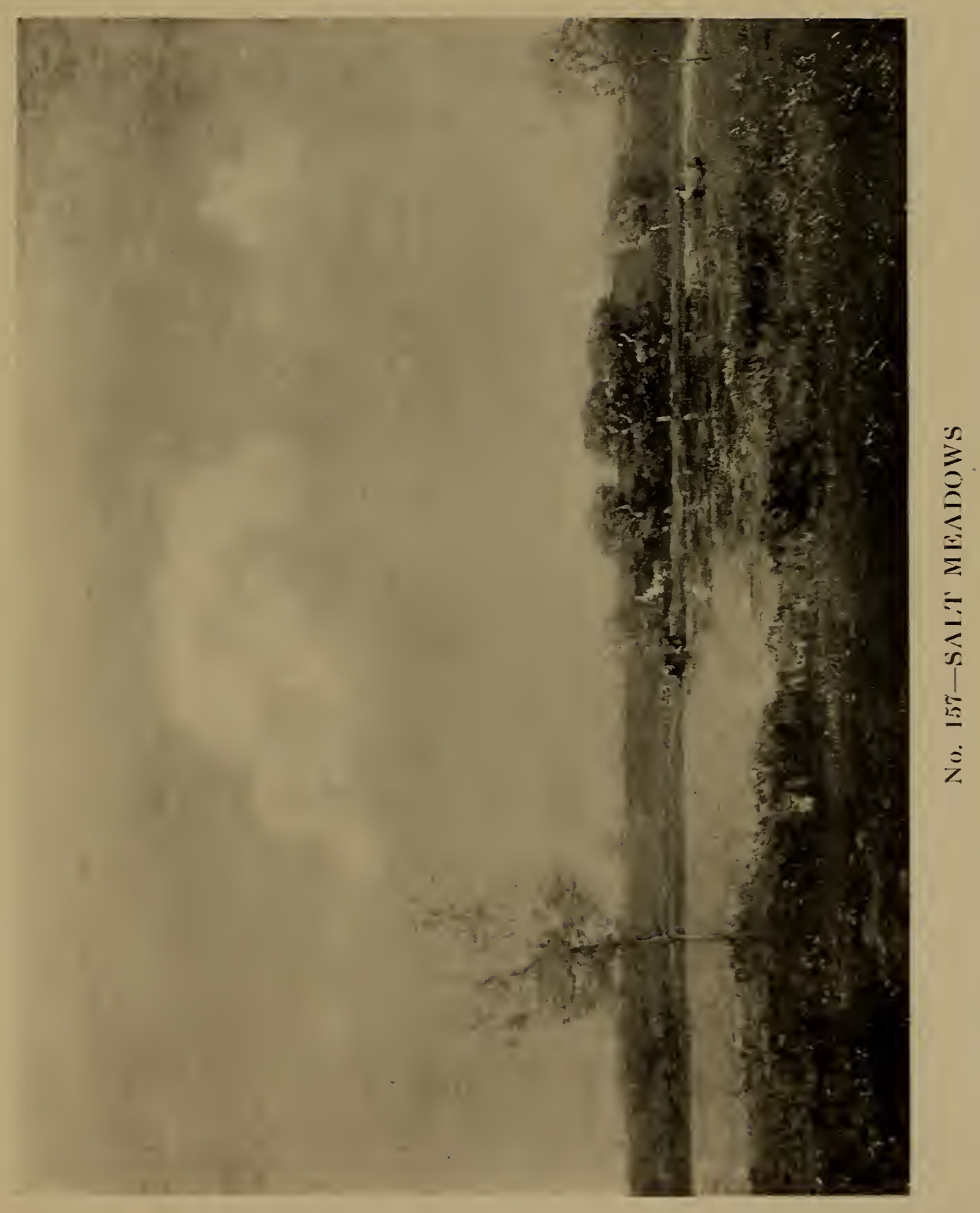


No. 159

\section{HENRY WARD RANGER, N.A.}

AMERICAN : $1858-1916$

\section{LONG POND}

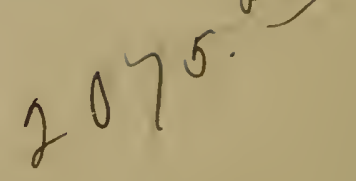

Height, 28 inches; length, 36 inches

THE grass and rocks in the foreground are flecked here and there with sunlight as it filters through the foliage of a group of three gnarled trees at the left whose branches stretch nearly across the canvas. A man attired in red flannel shirt and blue jeans stands at the edge of a pond, which reflects the pale blue of the sky overhead, and watches his companion row a boat across the water. The farther shore is enveloped in a blue haze, the foliage is tinged with the yellows and browns of early autumn, and there seems to be a touch of frost in the air.

Signed at left, and dated 1914.

No. 160

HENRY WARD RANGER, N.A.

American : $1858-1916$

MOONLIGHT

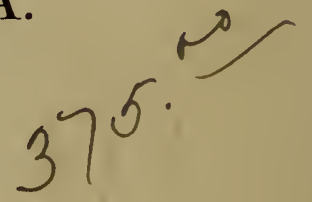

Height, 28 inches; length, 36 inches

Oven the narrow strip of water seen in the distance, and on the marshy land this side of it, the moon throws its silvery light. The foreground is roughened with rocks and tough grasses, and just beyond, to the left, a couple of workmen with their horses plod wearily along. Across the water, on which two ships lie lazily at anchor, the distant shore fades into the night. The ring of atmosphere around the moon is vibrant with its light, but outside this the sky is a dark turquoise and is spread aloft with the sombre clouds of night, with here and there a star showing.

Signed at left, and dated 1915. 


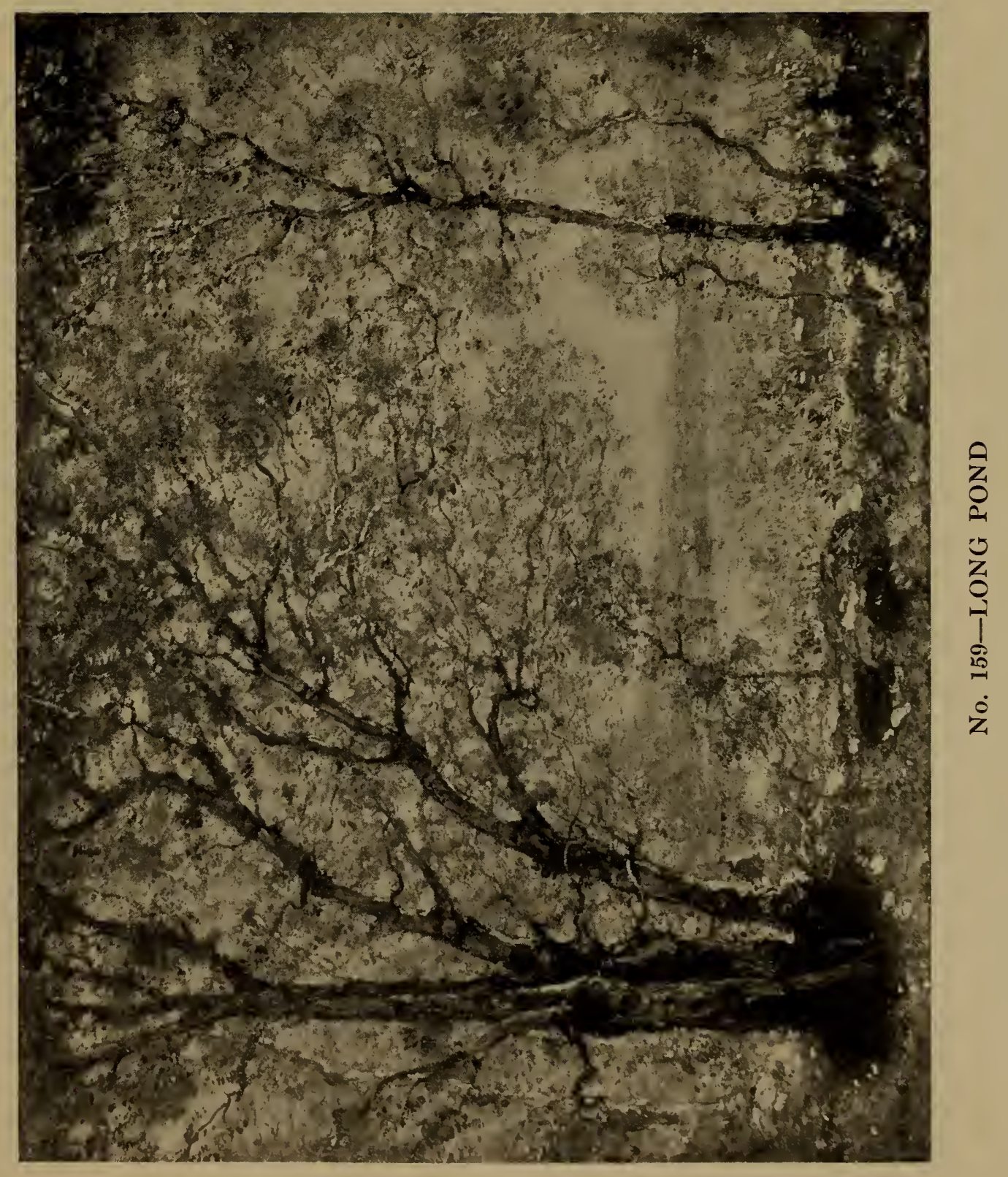


No. 161

\section{HENRY WARD RANGER, N.A.}

American : 1858-1916

\section{SUNSET ON THE MYSTIC RIVER, CONN.}

\section{Height, 28 inches; length, 36 inches}

The Corotesque trees in the foreground are silhouetted against a sky suffused with the soft golden light of the evening sun. At the foot of a tall, stately tree which spreads its fan-shape branches across the top of the canvas a man sits in quiet contemplation of the peaceful scene spread before him. On the river, which reflects the golden sky above, another man rows his boat shorewards, and across the water the soft shadowy outline of Mason's Island merges gradually into the pale blue distance. The sky is traversed with soft, fleecy clouds, richly colored in gold and purple. 


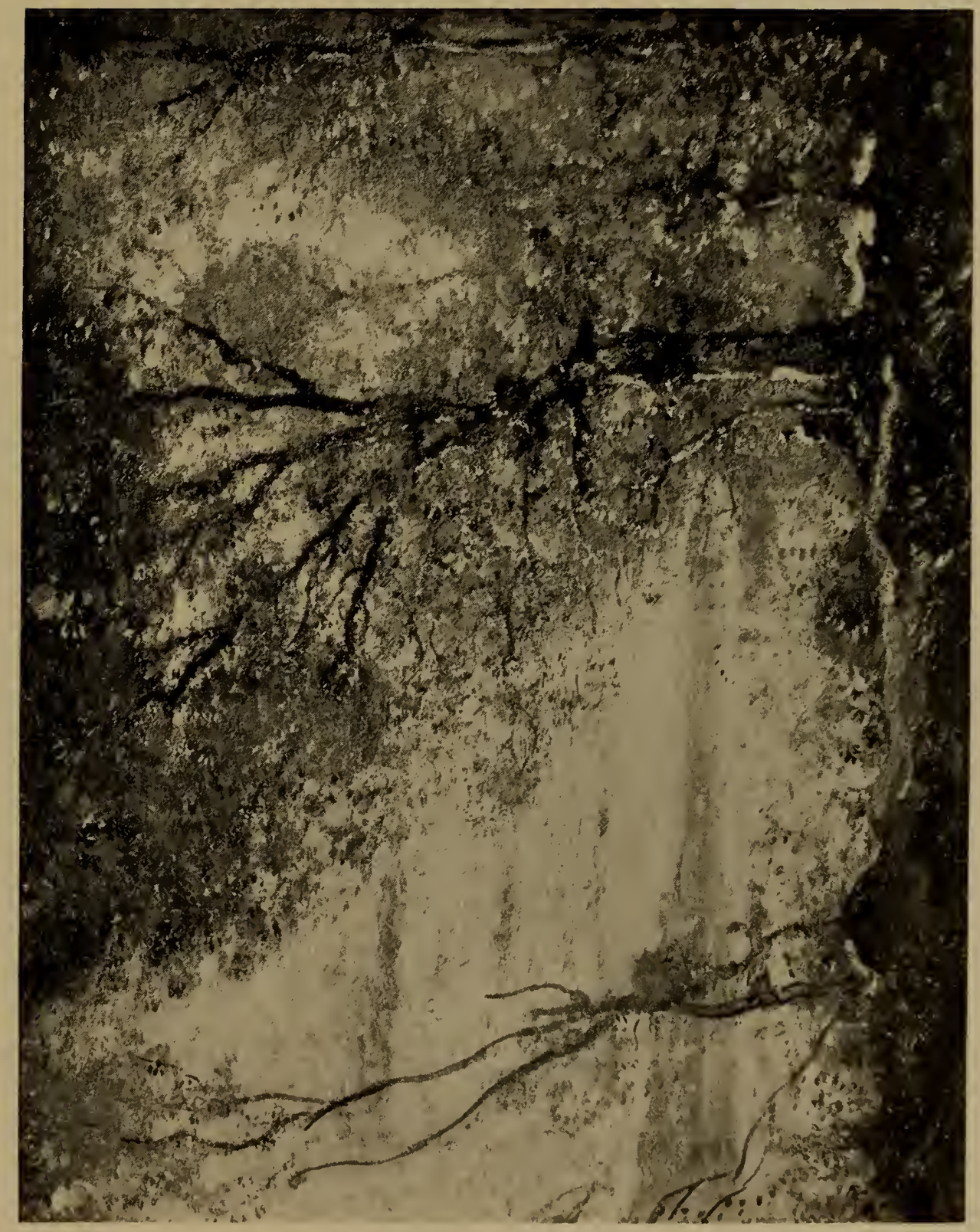

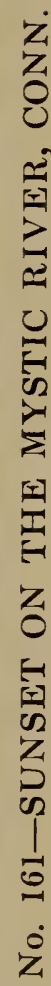


No. 162

\section{HENRY WARD RANGER, N.A.}

AnIERICAN : $1858-1916$

\section{SUNRISE AT NOANK}

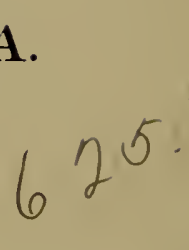

Height, 28 inches; length, 36 inches

Morning breaks on a busy scene over the waters of the Sound. The sun, just above the horizon, throws its shafts of warming light over the clear, cold water, and paints the clouds above it in rosy, cheerful tints. Men stand conversing in groups on the old weather-beaten docks at the left, and a few have gotten into the boats that will take them to their ships riding peacefully at anchor at the right. The distance is almost obliterated by the strong Turneresque light, and only the tall, slender masts are visible through it.

Signed at left, and dated 1915. 


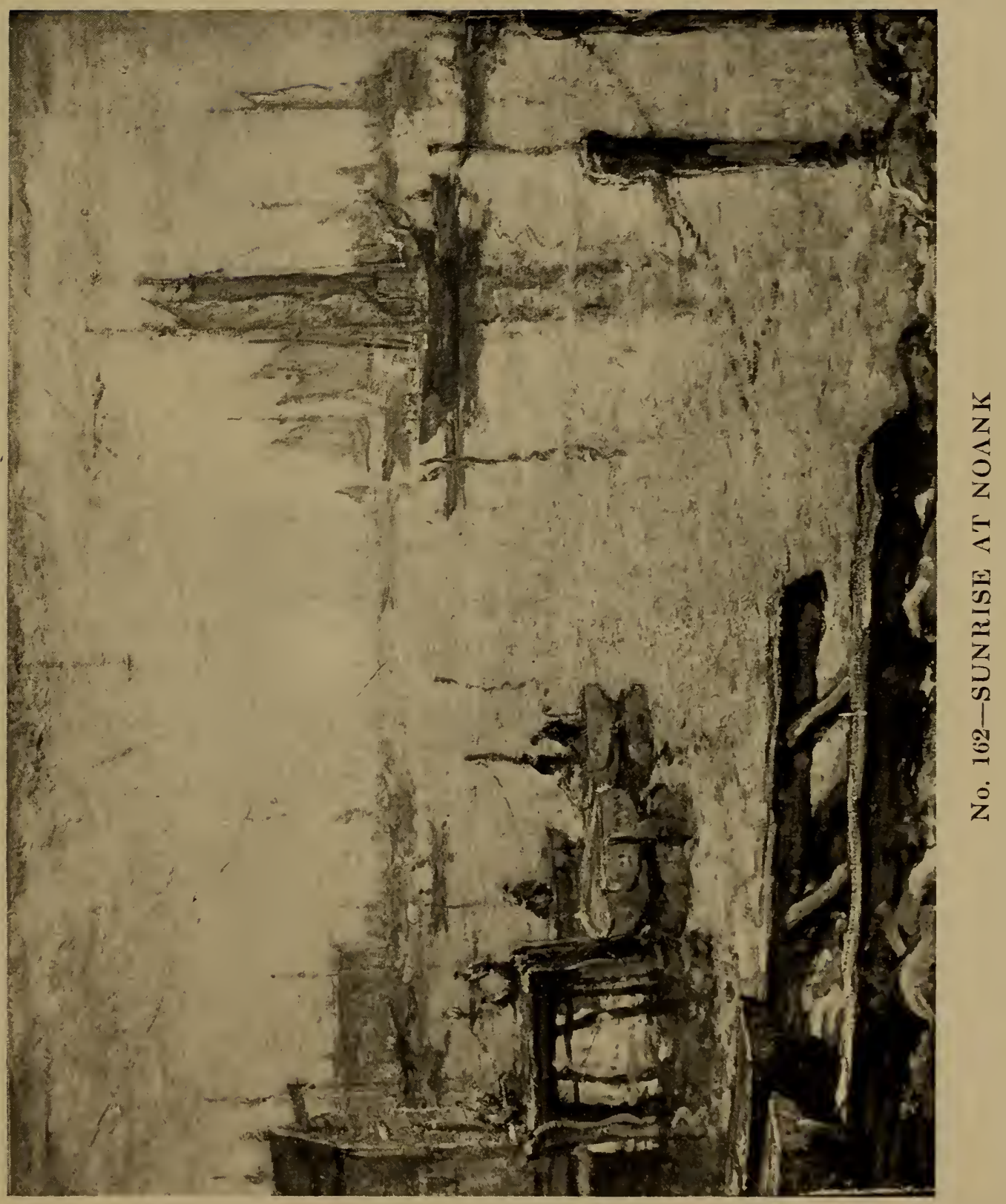


No. 163

HENRY WARD RANGER, N.A.

AMERICAN : 1858-1916

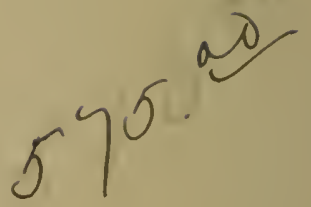

\section{LONG POINT MARSH}

Height, 28 inches; length, 36 inches

A MARshy foreground, in deep shadow, with some scraggly trees growing alongside a stone fence, is separated from the land in the distance by a small creek, the waters of which reflect the gray clouds and blue sky. Two men are fishing by the creek's edge. The sky is heavy with cumulus clouds overhead, becoming lighter in mass as they approach the horizon. 


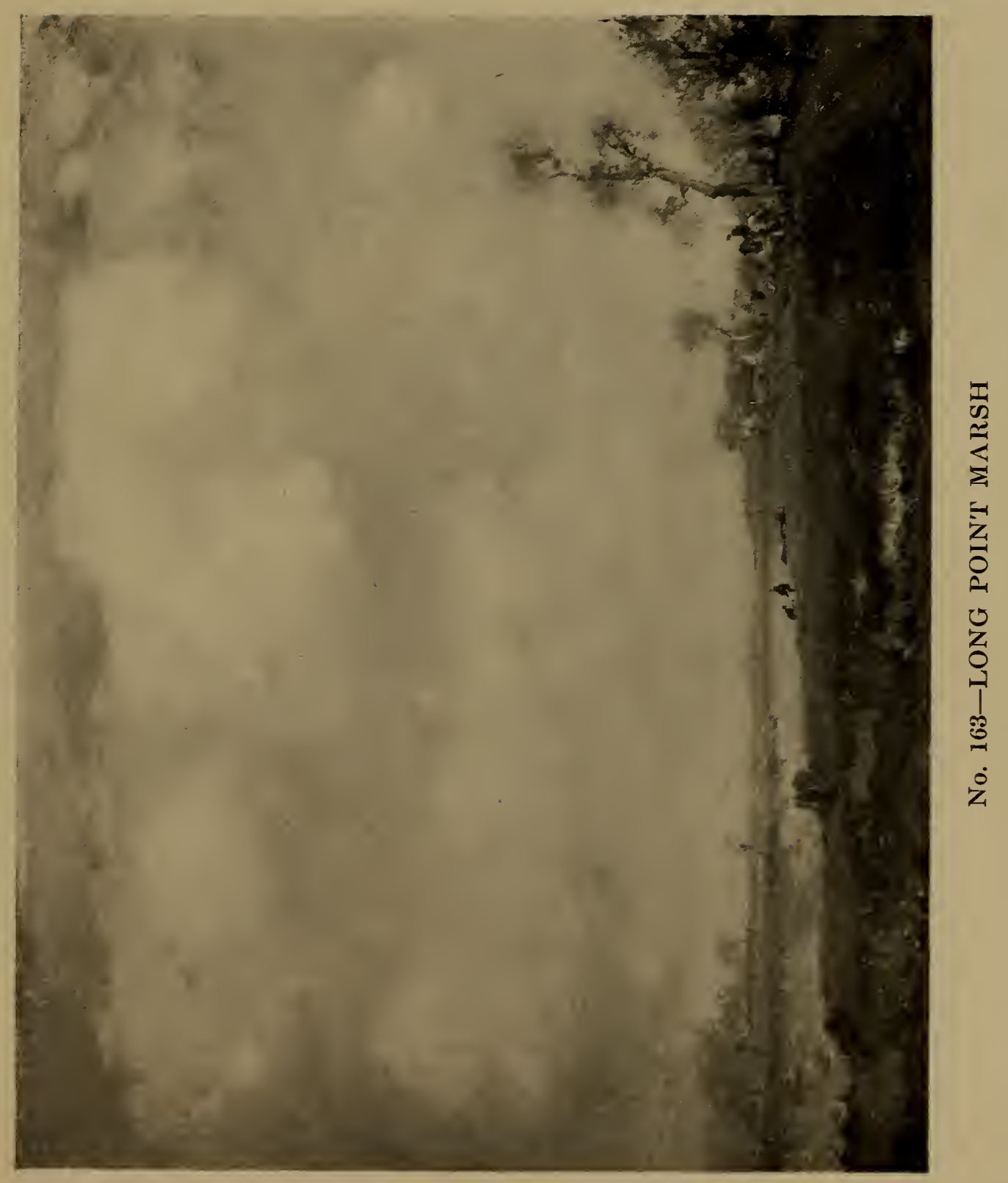


No. 164

HENRY WARD RANGER, NA.

American : $1858-1916$

ACROSS THE SOUND

6

Height, 28 inches; length, 36 inches

The eye rests for just a moment on the shadowed foreground with its graceful old elm tree standing guard over the old frame houses at the right, and then travels down the road and across the light blue waters of the Sound. A couple of fishing vessels lie at the wharf alongside the village store at the end of the road. The sky is a pale blue overhead becoming paler as it nears the horizon. Clouds filled with sunlight flit lightly across the sky and give the whole scene an air of cheerfulness. White sails reflecting the sunlight are dimly indicated in the distance.

\#

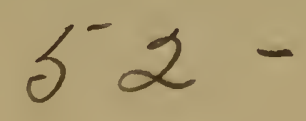

$53-$

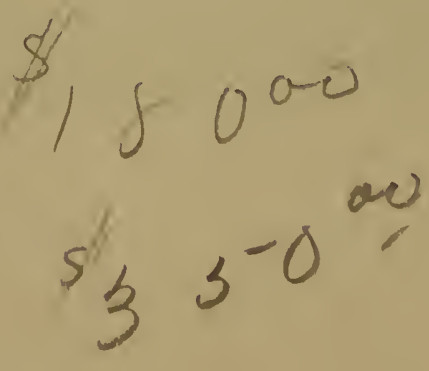




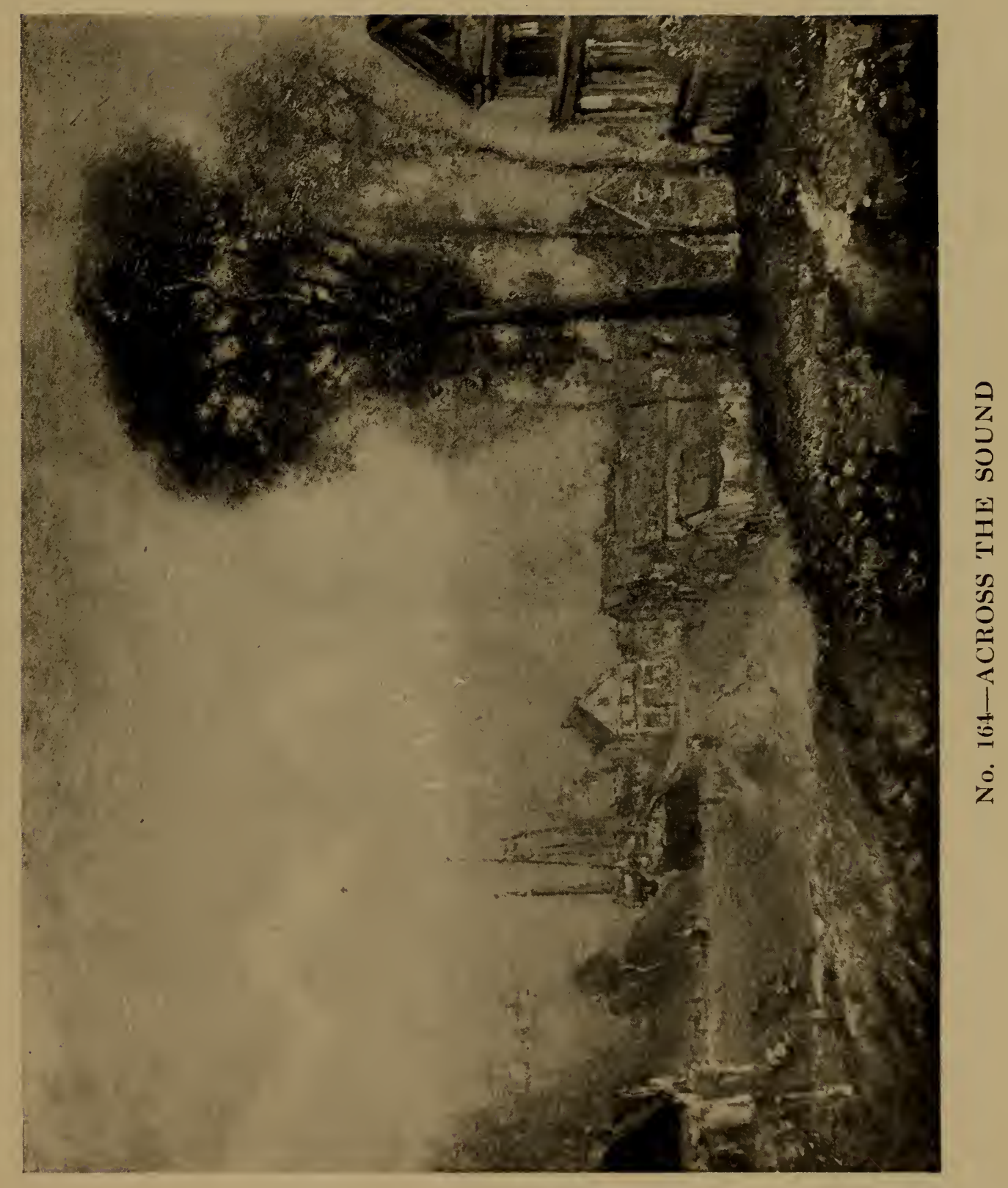





\section{LIST OF ARTISTS REPRESENTED}

AND THEIR WORKS 



\section{LIST OF ARTISTS REPRESENTED AND THEIR WORKS}

ARTAN, Louis

Dutch River Scene

CATALOGUE NUMBER

19

BLAKELOCK, Ralph Albert, N.A.

Landscape

BUNCE, William Gedney, N.A.

St. Georgio, Venice

At Anchor

Marine-Venice

The Mooring Buoy

Marine

Venetian Morning

90

Venetian Fishing Boats

94

Evening Glow

$9 \%$

COLMAN, Samuel, N.A.

Gathering Sea-weed

CONSTABLE, JoHN, R.A.

The Passing Storm

DaUbigny, Charles François (Attributed)

Evening Scene

DaVis, Charles Harold, N.A.

Autumn Sunlight

DESSAR, Louis Paul, N.A.

Pasture and Cattle

HOWE, Wilifia Henry, N.A.

Black and White Cows

Cattle in Pasture

Cattle 
INNESS, George, N.A.

Evening

KEVER, Jасов Smon Hendrik

Dutch Madonna

The Spinning Wheel

MILLET, J. F. (Attributed)

Head of a Boy

MURPHY, J. Francis, N.A.

Barns and Trees

Gusty Weather

Landscape

NEWMAN, Robert L.

Madonna and Child

POGGENBEEK, George

Landscape and Cattle

RANGER, Henry Ward, N.A.

Landscape

By the Lake

Summer's Greenery

Three Trees

On Fisher's Island

Breaking Waves

Woodland-Gray and Yellow

Woods in Springtime

Wide-spreading Branches

A Screen of Trees

A Fisher's Island Cove

Across the Valley

A Ledge of Rocks

31

Marine

32

Wood Interior

33

34

A Tropical Landscape

35

A Fisherman's Boat

36

Woodland

37 
RANGER, HeNRY WARD-Continued

A Windy Sky

Russet and Blue

Late Autumn

Rocks and Sea

Seashore Meadows

Cottage and Trees

Homeward Bound

An Old Country Farmhouse

In the Woods

Holland Landscape

The Meadow Farmhouse

A Country Road

Farmhouse and Willows

A Clump of Oak Trees

Near Boulogne

Willows at Bertier

Spring Landscape

Rocks and Dunes

June at Chateaugay

The Mirrored Oak

Moonlight-Noank

The Swamp Pasture

Marine-Green and Gold

Sunset-Red and Gold

A Clearing in the Woods

Old New England Houses

The Palisades

A Ledge in the Woods

Hilltop Pasture

Autumnal Hues

The Armory

Blue Sea and Golden Sky

Rocky Ledge, Connecticut

Nor'east Weather

Stony Cove and Headland

Top of Lord's Hill

Cloudland and Pasture

Autumn

The Sentinel 
RANGER, Henry Ward-Continued

A View of the Sound

An Arabesque

The Outskirts of the Woods

New York from Weehawken Heights

80

Along the Docks

81

A Noank Pasture

82

Autumn, Mason's Island

83

River and Trees

100

San Juan, Porto Rico

101

Sea and Shore

102

Rock Terrace

103

Landscape

104

Windy Skies

105

Farmhouse and Trees

106

Springtime Landscape

$10 \%$

November

108

Deserted Acres

109

A New England Port

110

Woodland Landscape

111

Seaside Meadows

112

Among the Birches

113

A Fresh Breeze

114

The River-Mason's Island

115

Sloping Hillside

116

Through the Woods

117

Along the Sound

118

Hilltops and Valley

119

The Brook

120

Marine: Blue and White

121

Old Sand Road

122

Marine: Clearing Off

123

Willows in Springtime

124

Landscape and Stream

125

Landscape-Along the Coast

126

The River

127

Marine: Calm Weather

128

Holland River Scene

129

Threatening Weather

130

A Good Harbor

131

Clouds and Sunshine 
RANGER, Henry Ward-Continued

Autumn's Glow

133

Noank, Connecticut

134

The Arched Trees

135

Autumn Wood Interior

136

Trees and Meadow

137

Hilltop Road

138

Early Spring

139

Early Morning on the Sound

140

The Edge of the Village

141

Bow Bridge, Moonlight

142

The Wood Lot

143

The Path through the Woods

144

Through the Trees

145

Before the Daylight is Gone $\quad 146$

October Landscape

147

The Quarry Hill

148

Misty Afternoon, Rathburn Pond 149

A New England Church $\quad 150$

Twin Trees

151

The White Farmhouse 152

Heavy Clouds 153

Clouds and Sunshine: Peconnuck Valley 154

The Barns $\quad 155$

Moonlight and Starshine 156

Salt Meadows 157

Cornfield: Lyme, Conn. 158

Long Pond 159

Moonlight $\quad 160$

Sunset on the Mystic River, Conn. 161

Sunrise at Noank 162

Long Point Marsh 163

Across the Sound 164

TEN KaTe, Herman Frederik Karel

An Old Street in Rouen 14

TWACH'TMAN, John Henry

The River's Edge 
WALKER, Horatio, N.A.

Pigs

96

WARDLE, Arthur

Lions-Moonlight

8

WEISSENBRUCH, Johannes Hendrik

Holland Landscape

86

WILliams, Frederick Ballard, N.A.

A Group of Fair Women

88

WIGgINS, Carleton, N.A.

Cows

16

WYAN'T, Alexander H., N.A.

Rough Country

89 


\title{
FOR INHERITANCE TAX
}

AND OTHER PURPOSES

\section{THE AMERICAN ART Association}

IS EXCEPTIONALLY WELL EQUIPPED

TO FURNISH

\section{INTELLIGENT APPRAISEMENTS}

OF

\author{
ART AND LITERARY PROPERTY
}

JEWELS AND PERSONAL EFFECTS OF EVERY DESCRIPTION

IN CASES WHERE

\section{PUBLIC SALES ARE EFFECTED}

A NOMINAL CHARGE ONLY WILL BE MADE

THE AMERICAN ART ASSOCIATION

MADISON SQUARE SOUTH

NEW YORK

TELEPHONE, 3346 GRAMERCY 
COMPOSITION, PRESSWORK

AND BINDING BY

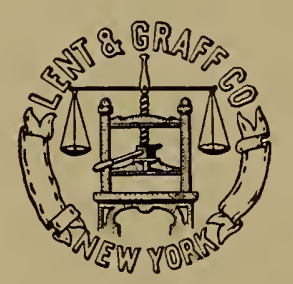



- 
ewman, Robert, "Madonna and Child," $8 \times 6$, Mrs. L. D. Montgomery ... "Trees," " $8 \times 6$

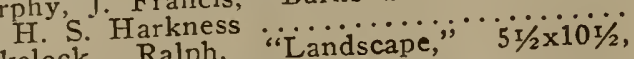
Blakelock, R. Ralph, "Lontgomery \#......”. (Panei), Bunce, Wm. "William Coffin ...................... Daubigny, Chas., (Attributed) w. HutchScene" (Panel), 81/2x15, John W. Hutch-

ince, Wm., "At Anchor" (Panel), $81 / 2 \times 13$,

Bunce, IVm., "At Anchor" (Panel), $81 / 2 \times 13$ Murphy, Francis, "Gusty Weather (Water Wardle. Arthur, "Lions-Moonlight", (Pastel), $91 / 2 \times 131 / 2$, Mirs. L. D. Montgomery .......

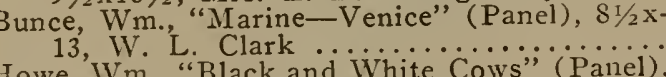
Howe, Wm., "Black and White Cows", (Panel), $10 \times 14$, F. Loeser \& Co ........, “ 113013,

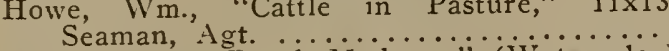

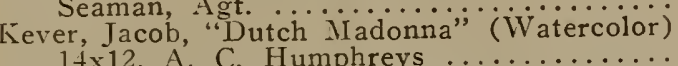

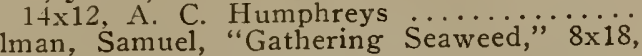
Seaman, Agt.

Ten Kate, Herman, "An Old Street in Rouen"; (Watercolor), 11x14, M. H. Marlin .....

Bunce, Wm., "The Hooring Buoy" (Panel) Wiggins, Carleton, "Cows," (Panel), 13x18,

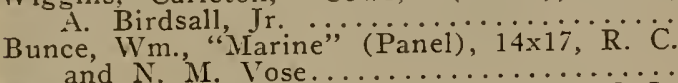
Millet, J. F., "Head of a Boy," 18x15, W. L. Clark $\ldots \ldots \ldots \ldots \ldots \ldots \ldots \ldots \ldots \ldots$
tan, Louis, “Dutch Aniei Pain Art News Co. . W..................

"Landscape" (Panel), 12x16, P. Chester.....

"By the Lake" (Mrillboard), 12x14, Bernet,

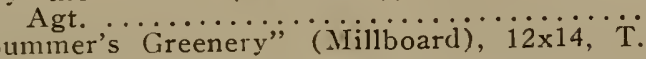

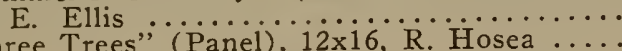
"Three Trees", (Panel), 12x16, R. Hosea ...

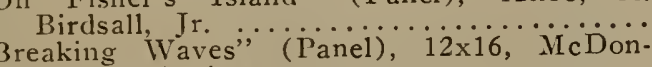
"Breaking Waves" (Panel), 12x16, McDon"Woodland-Gray and Yellow" (Millboard), 16x12, Geo. Broadhurst (Panel), 12xi6, $\ddot{R}$. C. and N. M. Vose ...'MUiliboard)..... "Wide-spreading Branches" ( "A Screen of Tres" (Panel), 12x16, IH. A.

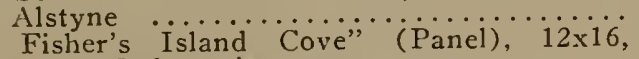
Wm. Kudenmeister "Icross the Valley," (Miliboard), 12x16, H. "A Ledge of Rocks"; (Panel), $12 \times 16$, Lero

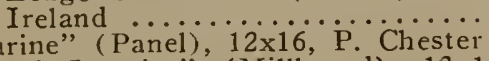

"Marine" (Panel), 12x16, P. Chester “Wood Interior" (Millboard). 12x16, H. S. "A Tropical Landscape.” (Panel), 12x16, Н̈. K. Butler ;........................... Fisherman's Boat" (Millboard), 12x16, A. Birdsall, Jr. $\ldots \ldots \ldots \ldots$ Mrs. L. D. ilont-

"Woodland" (Panel) : $12 \times 16, \ldots \ldots \ldots \ldots \ldots \ldots$. H.

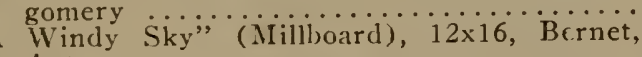

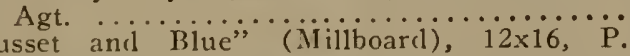

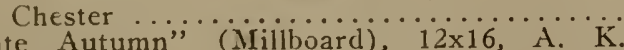

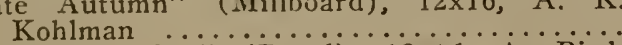

"Rocks and Sea"; (Panel), 12x16, A. Bird-

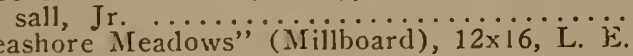
Ellis …...., 18.36, E. Roy Kendail. "Cottage and Trees," 18x36, E. Roy Kendall.

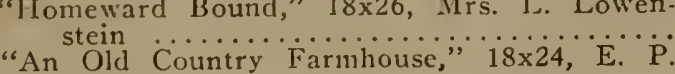
Earl

"In the Woods," 18x26, Leroy Ireland

"Holland I durdscape" 18x26 Cyril F Peck.

"The Meadow Farmlouse," 18×26, McDonough Galleries

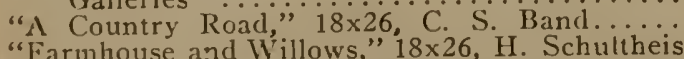

"A Clump of Oak Trees," $18 \times 26$, H. S. Hark

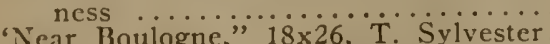

"Willows at Bertier" 18x26, P. Chesicr...

"Spring Landscape," 18×26, Seaman, Agt....

"Spring Landscape," $18 \times 26$, Seaman, Ag ..

"Rocks and Dunes," 25×30, K. Prentice.....

"June at Chateaugay," $18 \times 26$, C. V. Barton.... "Moonlight, Noank," 28×36, M. L. K. Rhein. "The Swamp Pasture," $28 \times 36$, R. Hosea.

"Marine, Green and Gold," 28x36, E. A. Milch "Sunset, Rerl and Gold," $28 \times 36$, John IIerron "A Art Mlearing in the ivoods," $28 \times 36$, Wi . $\mathrm{L}$. Clark.
"Old New England Houses," $28 \times 36, \mathrm{P}$. Chester "A Ledge in the IVoods," 28x36, H. Murray. "Hilltop Pasture,",28x36, McDonough Galleries "Autumnal Hues," $28 \times 36$, Rohlfs Gallery... "The Armory," 28x36, P. Chester......... Donough Galleries

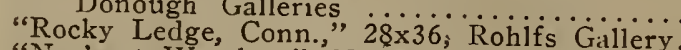
"Nor'east Weather,", 28x36, W. A. Johns... "Stony Cove and Headland," z8x36, McDon"Top of Lord's Hill,; $28 \times 36$, Holland Galleries "Cloudland and Pasture," 28x36, McDonough

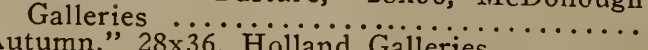
"The Sentinel." $28 \times 36$ C. V. Barton........... "A View of the Sound," $28 \times 36$, F. L. Mionta"An Arabessue,; $28 \ldots \ldots \ldots \ldots$ R. Hosea............ 625 "The Outskirts of the Woods," $28 \times 36$, Lorenz, "New York from Weehawken Hts,", $28 \times 36$, M. L. Rhein , "28. $36 \ldots \ldots \ldots \ldots \ldots \ldots$. "Along the Docks," "28x 36 , Jas. Blackma........ "Autumn, Mason's Island," 28x36, Jas. Blackman ........................ 1,050

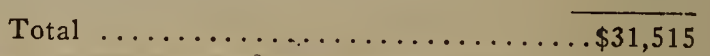

Murphy, J. Francis, "Landscape," $8 \times 12$, Henry

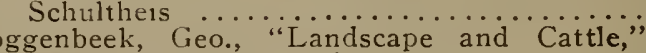
Poggenbeek, Geo., "Landscape and Cattle,"
(Watercolor). 12x8, John Levy .......... Weissenbruch, Johannes, "Holland Landscape," (Watercolor), 13x9. Holland Galleries . "; Dessar, Louis Paul, "Pasture and Cattle" Williams, F. Ballard, "Group of Fair Women" (Millboard), 12x16, A. P. Gardiner Wyant, Alex., "Rough Country," $13 \times 16$, Mr.

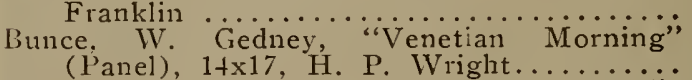

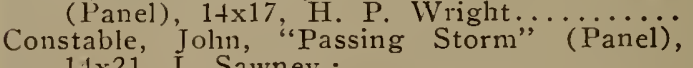

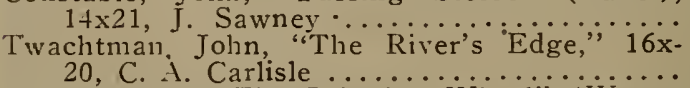
Kever, Jacob, "The Spinning Wheel" "ivatercolor), $15 \times 16$, Seaman, Agt. ........... Bunce, Wm. Gedney, "Venetian Fish-Boats"

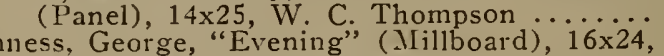
W. H. MacDonough (iva............... Holland Galleries

1,000

475
250

250

1,050

Bunce, W. Gedney, "Evening Glow"; (Panei), 15x25. Seaman, Agt. "Pane, Wm., "Cattle" (Panel), 16x20, John C....

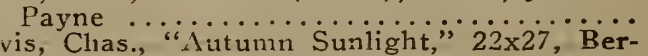

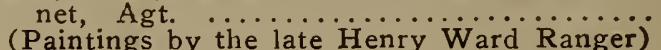
(Paintings by the late Henry Ward Ranger)
River and Trees" (Panel), 12x16, Mac"San Juan, Porto Rico"; (Panei), 16x12, L. E. "Sea and Shore," (Panel), 12x16, Dr. \#. C.

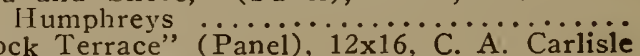
"Rock Terrace" (Panel), 12x16, C. A. Carlisle "Windy Skies" (Millboard). i2xib, John C. $^{\text {Donough }}$ "Farmhouse and Trees" (Miliboard), $12 \times 16$,

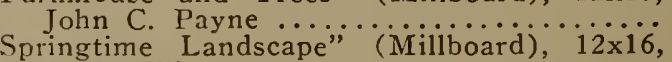

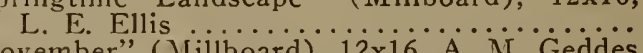

"November" (Millboard), 12xi6, A. M. Geddes

"Deserted Acres" (Millboard), 12x16, A. M.

"A New England Port”; (Panel), i2xi6, Bernet,

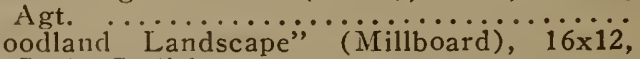

"Woodland Landscape" (Millboard), 16x12,

"Seaside Meadows" (Panel), 12xi6, J. C. McDonough . Birches; " (Miliboard), $12 \times 16$,

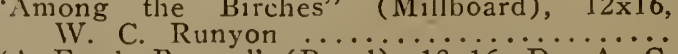
"A Fresh Breeze" (Panei), 12xi6, Di. A. C. Humphreys ............. "Panel), $12 \times 1 \%$

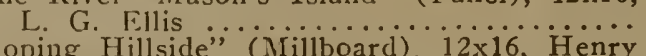
"Sloping Hillside" (Mrillboard). 12xi6, Henry

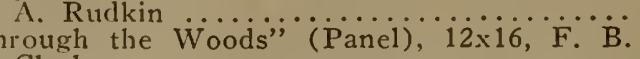

"Nlark . Sound" (Panel), 12x16, H. Schul-

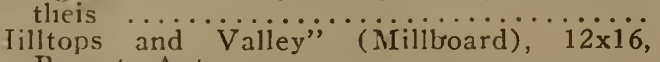
Bernet, Agt. (Miliboard), 12x16, Jolin C.

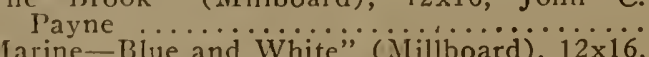

"Marine-Biue and White" (iillboard), $12 \times 16$,

"Old Sand Road"; (Millboard), 12х16, MacDonough frallery $. . . \ldots \ldots \ldots \ldots \ldots \ldots . . . .$. 


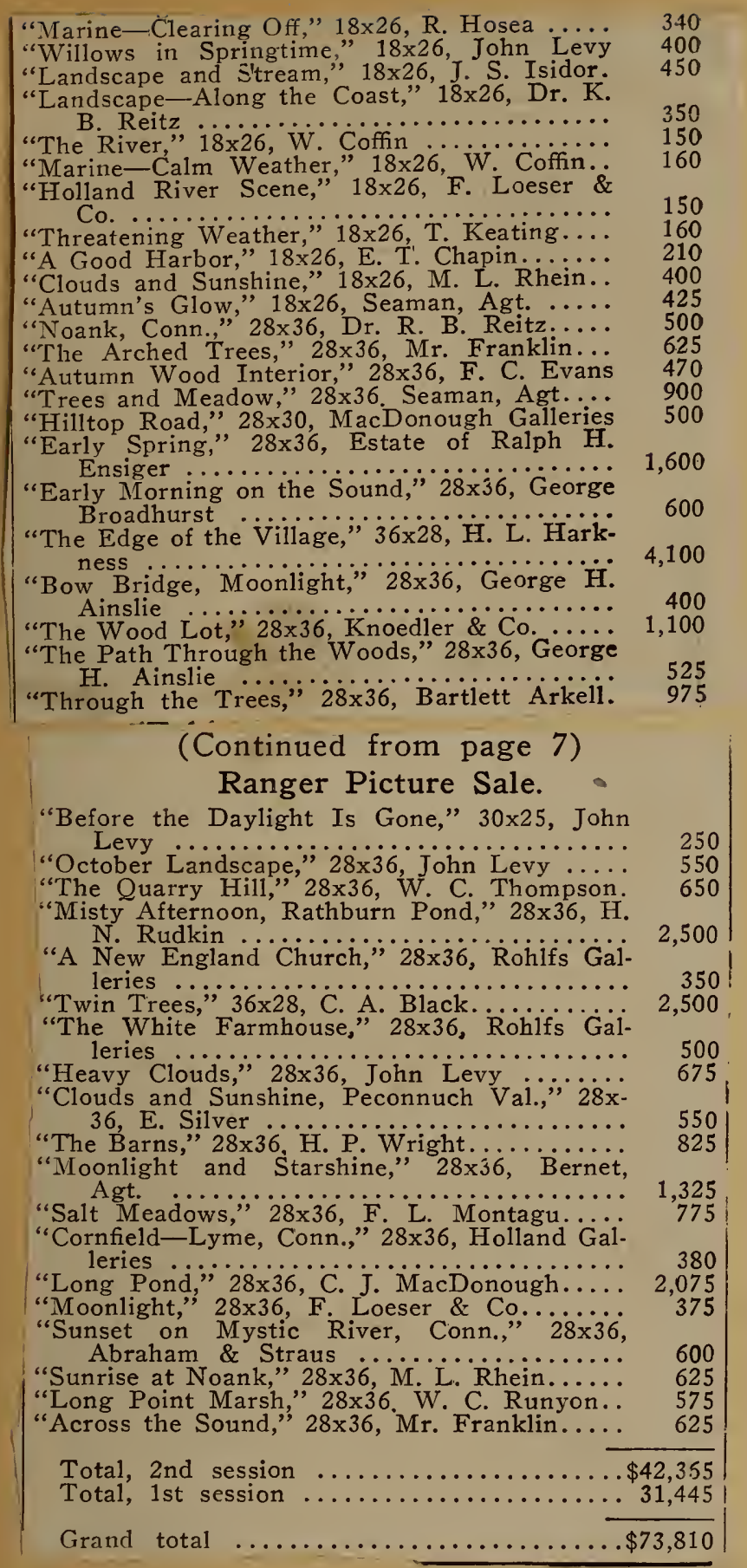


궁 

SMITHSONIAN INSTITUTION LIBRARIES

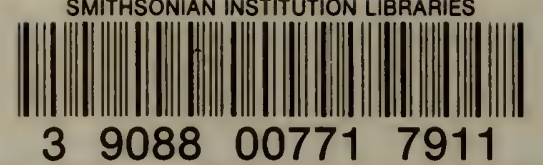

